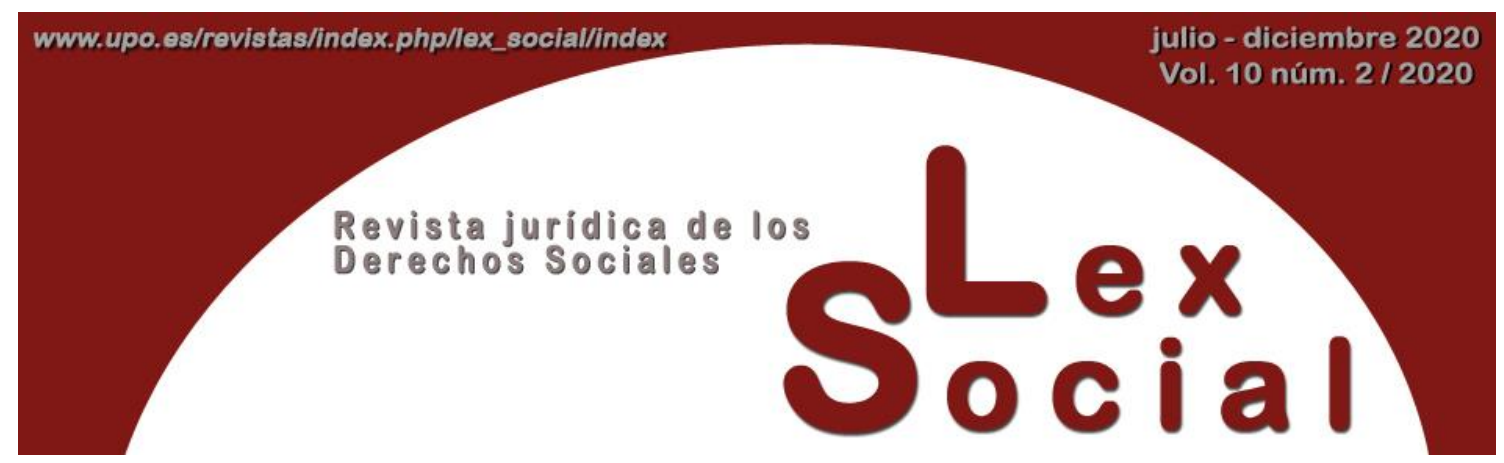

\title{
CRÓNICA DE LA JURISPRUDENCIA DEL COMITÉ EUROPEO DE DERECHOS SOCIALES - 2018 y 2019*
}

\section{REVIEW OF THE EUROPEAN COMMITTEE OF SOCIAL RIGHTS' CASE LAW IN 2018 AND 2019}

\author{
LUIS JIMENA QUESADA \\ Catedrático de Derecho Constitucional \\ Universitat de València
}

Artículo recibido el 20 de mayo de 2020

Artículo aceptado el 3 de junio de 2020

DOI: https://doi.org/10.46661/lexsocial.5139

\section{RESUMEN}

La presente crónica abarca dos años (2018 y 2019) en los que las actividades del Comité Europeo de Derechos Sociales adquirieron una dimensión más amplia y significativa en la protección de la dignidad humana. En primer lugar, la crónica incluye principalmente una selección de las conclusiones adoptadas por el Comité a través del sistema de informes que se refieren a los grupos temáticos "Derechos laborales" y "Niños, familias y migrantes". En segundo lugar, los logros de 2018 y

\footnotetext{
* Deseo mostrar mi sincera gratitud a los Profesores Enrique Álvarez Conde y Rosario Tur Ausina, por su resuelto compromiso facilitando la publicación de las crónicas del Comité Europeo de Derechos Sociales desde 2008 hasta 2017 en la Revista Europea de Derechos Fundamentales, que dirigieron magistralmente y consolidaron situándola como medio de difusión acreedor de los indicios más altos de calidad, ofreciendo durante años oportunidades de publicación de excelentes trabajos a numerosos investigadores e investigadoras, debiendo lamentarse que las autoridades universitarias responsables no hayan mantenido una revista puntera en su ámbito. Al tiempo, debo expresar asimismo mi agradecimiento a los Profesores Manuel Terol Becerra y Carmen Salcedo Beltrán por haberme propuesto y facilitado, en su tarea compartida de co-dirección, que se dé seguimiento a la Crónica (en este caso, con la referente a 2018 y 2019) en la Revista Lex Social, la cual está consolidándose igualmente como un referente nacional e internacional en el terreno de los derechos sociales. En esta ocasión, dedico la presente Crónica a los Profesores Álvarez Conde y Terol Becerra, a ambos como homenaje "in memoriam" con todo afecto y aprecio. Por lo demás, el presente trabajo se ha elaborado en el marco del Grupo de Investigación "Derechos Humanos y Carta Social Europea" de la Universitat de València cuya Directora es la Profesora Salcedo Beltrán (referencia: GIUV2013-148).
} 
2019 en términos de reclamaciones colectivas han robustecido el potencial de la Carta para ofrecer protección a las situaciones de vulnerabilidad y a las personas beneficiarias más inermes. Desde esta perspectiva, la crónica destaca las conclusiones y decisiones del Comité que son, tanto de gran significación para la protección de los derechos sociales fundamentales, como de relevancia práctica para todas las instituciones y actores involucrados en hacer que los derechos de la Carta sean reales y efectivos. Finalmente, el autor concluye que sensibilizar sobre la jurisprudencia del Comité, siguiendo el espíritu del "Proceso de Turín", es la mejor manera de consolidar la Carta Social Europea como verdadero Pacto europeo para la estabilidad social de los tres pilares del Consejo de Europa: democracia, Estado de Derecho y derechos humanos.

Palabras Clave: Carta Social Europea, Sistema de Informes, Procedimiento de Reclamaciones Colectivas, Situaciones de Vulnerabilidad, Derechos Sociales y Laborales, Proceso de Turín.

\begin{abstract}
This review covers two years (2018 and 2019) in which the activities of the European Committee of Social Rights took on a broader and more significant dimension in the protection of human dignity. Firstly, the review mainly contains a selection of the conclusions adopted by the Committee through the reporting system belonging to the thematic groups "Labour rights" as well as "Children, Family and Migrants". Secondly, the achievements of 2018 and 2019 in terms of collective complaints strengthened the Charter's potential for protecting those situations of vulnerability and beneficiaries at greatest disadvantage. From this perspective, the review highlights conclusions and decisions from the Committee which are both of great significance for the protection of fundamental social rights and of practical relevance for all institutions and stakeholders involved in making Charter rights real and effective. Finally, the author concludes that raising awareness of the Committee's case-law, in the spirit of the "Turin Process", is the best way to consolidate the European Social Charter as a veritable European pact for the social stability of the Council of Europe's three pillars: democracy, rule of law and human rights.
\end{abstract}

KeYwORDS: European Social Charter, Reporting System, Collective Complaints Procedure, Situations of Vulnerability, Social and Labour Rights, Turin Process.

SUMARIO

I. ASPECTOS INTRODUCTORIOS.

II. LA JURISPRUDENCIA RELATIVA AL SISTEMA DE INFORMES DURANTE 2018:

1. Balance conjunto:

1.1. El lado negativo: principales conclusiones de no conformidad. 
1.2. El lado positivo: progresos significativos constatados y cautelas interpretativas.

2. La situación española.

III. LA JURISPRUDENCIA RELATIVA AL SISTEMA DE INFORMES DURANTE 2019:

\section{Balance conjunto:}

\subsection{Aspectos generales.}

\subsection{Aspectos específicos.}

2. La situación española.

IV. LA JURISPRUDENCIA REFERENTE AL MECANISMO DE RECLAMACIONES COLECTIVAS DURANTE 2018 y 2019:

1. Observaciones preliminares.

2. Jurisprudencia sobre situaciones de vulnerabilidad y Derecho antidiscriminatorio.

3. Jurisprudencia sobre aspectos referentes a formación profesional y protección social bajo diversas dimensiones (igualdad y libertad) y en diversos sectores.

4. Reclamaciones sobre derechos laborales y sindicales o de acción colectiva.

V. PERSPECTIVAS JURISPRUDENCIALES.

Bibliografía.

\section{ASPECTOS INTRODUCTORIOS}

Antes de entrar en el contenido propio de la jurisprudencia del CEDS en los años 2018-2019, resulta insoslayable advertir que la presente crónica se redacta en el difícil contexto de la pandemia provocada por el coronavirus que empezó a ponerse en evidencia a escala mundial desde principios de 2020. En efecto, la crisis sanitaria y humanitaria causada por el COVID-19 no debe degenerar en una crisis general de derechos humanos y, a tal efecto, la CSE y la jurisprudencia del CEDS están llamadas a desempeñar un papel fundamental para garantizar la efectividad de los derechos sociales. Aunque de ello proceda hacerse eco con detalle lógicamente con motivo de la próxima crónica de 2020, deseo anticipar que, como no podía ser de otra forma, el CEDS se ha visto irremediablemente llamado a reaccionar ante esta crítica situación; y lo ha hecho con la Observación interpretativa del CEDS (adoptada el 21 de abril de 2020) sobre el derecho a la protección de la salud en tiempos de pandemia, con una técnica similar a la que utilizó con motivo de la crisis de las personas refugiadas de 2015, es decir, sin esperar a final de cada año o ciclo de control para adoptar este tipo de observaciones, sino reaccionando con la urgencia exigida por el momento. Por lo demás, como en el resto de ámbitos, incluidas las instancias jurisdiccionales nacionales y europeas, el CEDS ha 
debido adaptar en 2020 sus métodos de trabajo a las circunstancias marcadas por el COVID-19, manteniendo sus primeras reuniones y sesiones por videoconferencia.

Dicho lo cual, como en los años precedentes, desde 2014, la actividad del Comité Europeo de Derechos Sociales (CEDS) en los años 2018 y 2019 se ha desarrollado básicamente sobre la base de tres grandes áreas: de un lado, en el terreno institucional, la dinamización del "proceso de Turín" (iniciado con la importante Conferencia política de alto nivel celebrada en Turín los días 17-18 de octubre de 2014) para reforzar la efectividad de los derechos consagrados en la Carta Social Europea (CSE) y las sinergias con la Unión Europea (UE), así como intercambios relevantes (incluidos los de diplomacia y diálogo judicial); de otro lado, en el plano jurisprudencial, la consolidación del nuevo sistema de informes adoptado por el Comité de Ministros en su 1196a reunión los días 2-3 de abril de 2014 [CM(2014)26] con objeto de hacer éste más eficiente y eficaz (en términos de reducción de los plazos de resolución y de garantía efectiva de los derechos reconocidos en la CSE) y de simplificar dicho sistema con respecto a los Estados Partes que hayan asumido el procedimiento de reclamaciones colectivas; y, en tercer lugar, en ese mismo ámbito jurisprudencial, la apuesta por seguir dotando de mayor visibilidad e impacto justamente al procedimiento de reclamaciones colectivas.

En lo que concierne al primer ámbito, como continuación de la Conferencia inicial de Turín celebrada en octubre de 2014 y de eventos posteriores que tuvieron lugar en 2015 (Conferencia de alto nivel sobre "El futuro de la protección de los derechos sociales" organizada en Bruselas en febrero en el marco de la Presidencia belga del Consejo de Europa), en 2016 (Conferencia interparlamentaria de los 47 Estados miembros del Consejo de Europa dedicada a la CSE, organizada en Turín en marzo por el Consejo de Europa en colaboración con la Cámara de Diputados italiana y con el Municipio de Turín; o Debate temático sobre "Derechos sociales en Europa: la puesta en práctica de la Carta Social Europea a nivel regional", organizado en octubre por la Cámara de las Regiones en el marco de la $31^{\mathrm{a}}$ sesión del Congreso de Poderes Locales y Regionales del Consejo de Europa) o en 2017 (Conferencia internacional sobre "Los derechos sociales en la Europa de hoy: el papel de las Cortes nacionales y europeas" organizada en febrero de 2017 en Nicosia por la Presidencia semestral chipriota del Comité de Ministros del Consejo de Europa, o publicación a finales de junio de 2017 del Informe "El Proceso de Turín: reforzar los derechos sociales en Europa"1, de la Asamblea Parlamentaria del Consejo de Europa, APCE), lo cierto es que el año 2018 no contó con actividades dinamizadoras del "Proceso de Turín", que en cambio fueron retomadas por la Presidencia semestral francesa del Comité de Ministros con la organización el 19 de septiembre de 2019 en Estrasburgo del Seminario internacional "Reforzar la protección de los derechos sociales en Europa para conseguir mayor unidad e igualdad".

Con respecto a los intercambios de diplomacia y diálogo judicial, merece la pena mencionar dos de ellos que tuvieron lugar en 2018 y 2019, respectivamente: por un lado, el 25 de enero de 2018 se mantuvo en Estrasburgo una reunión entre una delegación de la Corte Constitucional ucraniana y el CEDS con respecto a la protección de derechos

\footnotetext{
${ }^{1}$ La relatora fue la parlamentaria andorrana Silvia Eloïsa Bonet. El contenido del Informe vino asumido por la Resolución nº 2180(2017) y la Recomendación nº 2112(2017) de la propia APCE.
} 
sociales constitucionales a nivel nacional ${ }^{2}$, particularmente sobre el derecho a prestaciones sociales, como consecuencia de un gran número de recursos individuales formulados ante la Jurisdicción Constitucional de dicho país y la toma en consideración, en la tarea exegética de esa Alta Jurisdicción Nacional, de la jurisprudencia internacional en la materia elaborada por el TEDH y por el CEDS ${ }^{3}$; por otro lado, el 4 de octubre de 2019 se organizó en la Escuela Diplomática de Madrid, bajo el título "Respetando los derechos sociales: lecciones aprendidas en cuanto a su eficacia", el "Primer Encuentro de Diálogo entre el Comité Europeo de Derechos Sociales y la Corte Interamericana de Derechos Humanos" organizado por el Servicio de la Carta Social Europea del Consejo de Europa con el apoyo de la Corte Interamericana, del Gobierno Español y del Max Planck Institute for Comparative Public Law and International Law de Heidelberg.

En lo atinente a los aspectos segundo y tercero (terreno jurisprudencial propiamente dicho en donde ha desplegado su actividad el CEDS), la presente crónica referente a 2018 y 2019 se centrará tanto en las conclusiones alcanzadas en el contexto del sistema de informes como en las decisiones (de admisibilidad y de fondo) adoptadas en el marco del mecanismo de reclamaciones colectivas: en este último ámbito, se ha adoptado alguna decisión sobre petición de medidas inmediatas que no ha sido atendida por el CEDS, lo cual no obsta a su potencial envergadura en términos de justicia cautelar (e incluso para eventualmente supervisar la ejecución de decisiones de fondo condenatorias). A este respecto, conviene mencionar una última modificación del Reglamento interno del CEDS adoptada el 10 de septiembre de 2019 (en su 308 a sesión) que afectó, entre otras disposiciones, a su artículo 36 (medidas inmediatas), de tal manera que, desde dicha modificación, ya no está habilitado el CEDS para adoptarlas solamente desde el momento de la declaración de la admisibilidad de una reclamación (pero no antes, como sucedía hasta ahora), sino en cualquier momento del procedimiento desde el registro de la reclamación (esto es, sin necesidad de esperar ya los cuatro a seis meses de media que suele tardar el CEDS en adoptar una decisión sobre la admisibilidad).

Expresado lo cual, desde la óptica política-normativa (los textos que configuran el "sistema" de CSE), en los años 2018 y 2019 no se produjo ningún avance significativo a la luz de la Declaración de 12 de octubre de 2011 del Comité de Ministros del Consejo de Europa sobre el cincuenta aniversario de la CSE de 1961, que postuló la necesidad de acabar con diversas inaceptables asimetrías de la Europa social (entre los Estados miembros del Consejo de Europa -47- que han aceptado la CSE -43- y los que no -todavía

\footnotetext{
${ }^{2}$ En este mismo escenario en 5 de abril de 2019 fue publicado el "Informe sobre la evaluación de las necesidades en el ámbito de los derechos sociales en Ucrania", que fue preparada tras la misión de evaluación efectuada en Kiev en diciembre de 2018 en el marco del proyecto del Consejo de Europa "Enmarque de la cooperación para el desarrollo de los derechos sociales en Ucrania", y en el que se identificaron cinco ámbitos prioritarios: los derechos de las personas con discapacidad bajo el ángulo del artículo 15 CES, los derechos de las personas mayores en el marco del artículo 23 CSE, los derechos de la infancia y la juventud en los artículos 7 y17 CSE, el derecho a disfrutar el nivel más elevado posible de salud del artículo 11 CSE y el derecho a la asistencia social y médica del artículo 13 CSE.

${ }^{3}$ Dicho encuentro fue una continuación del intercambio previamente mantenido en febrero de 2017 en Kiev, entre el Tribunal Constitucional de Ucrania y el CEDS, en el que se discutió específicamente sobre la protección constitucional del derecho a la seguridad social a la luz del artículo 12 CSE y de la jurisprudencia del CEDS.
} 
siguen con dicha asignatura pendiente Liechtenstein, Mónaco, San Marino y Suiza-; entre los Estados que han ratificado la CSE revisada de 1996 -34- y los que todavía siguen vinculados por la CSE original de 1961 -9-; y entre los que han aceptado el procedimiento de reclamaciones colectivas -15 - y todos los demás) ${ }^{4}$.

Para completar la presente introducción, ha de recordarse una vez más que España ratificó la CSE de 1961 el 6 de mayo de 1980 y el Protocolo adicional de 1988 el 24 de enero de 2000, debiendo insistirse nuevamente en que todavía sigue sin vincularse nuestro país por el Protocolo de reclamaciones colectivas de 1995 (ni siquiera firmado por el momento) y por la CSE revisada de 1996 (cuya firma se produjo el 23 de octubre de 2000). Como he denunciado en crónicas precedentes, semejantes asignaturas pendientes resultan tanto más llamativas y, tal vez paradójicas, cuanto que España sí ratificó en cambio, el 23 de septiembre de 2010, el más reciente Protocolo facultativo al Pacto de Derechos Económicos, Sociales y Culturales de la ONU, adoptado por la Asamblea General en la emblemática fecha del 10 de diciembre de 2008, y mediante el que se establece un mecanismo de comunicaciones o denuncias individuales similar al instaurado a través de otros instrumentos de Naciones Unidas (Protocolos Facultativos al Pacto de Derechos Civiles y Políticos o a la Convención sobre los derechos de las personas con discapacidad, o la Convención sobre la eliminación de todas las formas de discriminación racial).

Expresado lo cual, como dato interesante que debería invitar al optimismo cabe observar que el 1 de febrero de 2019 el Consejo de Ministros del Gobierno de España adoptó el Acuerdo por el que se dispone la remisión a las Cortes Generales de la Carta Social Europea revisada y se autoriza la manifestación del consentimiento de España para obligarse por dicha Carta. Sin embargo, la ratificación por parte del Parlamento español quedó frustrada al disolverse las Cámaras mediante la convocatoria de elecciones generales el 28 de abril de 2019. La incertidumbre continúa tras la formación de Gobierno después de las últimas elecciones generales celebradas el 10 de noviembre de $2019^{5}$.

Con estas pinceladas preliminares, es necesario recordar asimismo que la jurisprudencia de la máxima instancia de garantía de la CSE (el CEDS) adquiere la forma de "conclusiones" en el caso de la interpretación jurídica elaborada en el marco del sistema de informes establecido mediante la Carta de 1961 y de "decisiones" (de admisibilidad y de fondo, así como eventualmente sobre medidas inmediatas) en el supuesto de la interpretación jurídica desarrollada en el procedimiento de reclamaciones colectivas introducido a través del Protocolo de 1995. Debe añadirse, por consiguiente, que el compromiso internacional de los Estados Partes con respecto a la Carta Social Europea (la de 1961 y la revisada de 1996) comporta el carácter vinculante no sólo de las

\footnotetext{
${ }^{4}$ Efectivamente, la última ratificación de la CSE revisada de 1996 se produjo el 18 de marzo de 2016 (Grecia), mientras que la última aceptación del procedimiento de reclamaciones colectivas tuvo lugar el 4 de abril de 2012 (República Checa).

5 Véase SALCEDO BELTRÁN, C., y JIMENA QUESADA, L.: "La Carta Social Europea revisada (Constitución Social de Europa) y el Acuerdo del Consejo de Ministros: el compromiso con los derechos y ¿con sus garantías?”, 2019, en https://atdcuartomundo.es/2019/02/04/espana-mas-cerca-de-la-carta-socialeuropa-revisada-y-tambien-de-sus-garantias/ (4 de febrero de 2019; último acceso 16 de junio de 2020), pp. 1 y 2.
} 
disposiciones de ella, sino también de la jurisprudencia emanada del CEDS en ambos sistemas (el de informes y el de reclamaciones colectivas). Naturalmente, ambos sistemas se retroalimentan, lo cual se manifiesta en que el CEDS se inspira y cita en sus "decisiones de fondo" la jurisprudencia elaborada en el sistema de informes y, paralelamente, se inspira y cita en sus "conclusiones" la más reciente jurisprudencia desarrollada a través de la resolución de las reclamaciones colectivas. Por lo demás, y al hilo de lo acabado de reseñar, debe recalcarse esta noción moderna de "jurisprudencia" del CEDS (así se denomina oficialmente y como tal puede encontrarse en el sitio web de la Carta Social Europea -www.coe.int/socialcharter), es decir, de juris-dictio o de "decir el Derecho" contenido en la CSE con carácter último.

\section{LA JURISPRUDENCIA RELATIVA AL SISTEMA DE INFORMES DURANTE 2018}

\section{Balance conjunto}

\subsection{El lado negativo: principales conclusiones de no conformidad}

Las Conclusiones adoptadas en el marco del sistema de informes por el CEDS relativas a 2018 versaron sobre el grupo temático III (para el período de referencia enero de 2013 a diciembre de 2016), centrado especialmente en "Derechos relacionados con el trabajo", esto es, los artículos 2 (derecho a condiciones de trabajo equitativas), 4 (derecho a una remuneración equitativa), 5 (libertad sindical), 6 (derecho a la negociación colectiva), 21 (derecho a la información y consulta de los trabajadores en el seno de la empresa), 22 (derecho a tomar parte en la determinación y mejora de las condiciones laborales y del entorno de trabajo), 26 (derecho a la dignidad en el trabajo), 28 (derecho de los representantes de los trabajadores a la protección en la empresa y a las facilidades que se les deben conceder) y 29 (derecho a la información y consulta en los procedimientos de despido colectivo). El CEDS evaluó la situación de treinta cinco países ${ }^{6}$ y recibió comentarios de sindicatos nacionales y organizaciones de empleadores sobre los Países Bajos y España (en nuestro caso, registraron observaciones, en fecha 27 de abril de 2018, los sindicatos CCOO y UGT).

Como balance general, en su sesión de enero de 2019, el CEDS adoptó 580 conclusiones y declaró 206 violaciones de la Carta y 276 constataciones de conformidad; por otro lado, en 98 supuestos, el CEDS no pudo evaluar la situación debido a la ausencia de información insuficiente, aplazando consecuentemente su conclusión. Las

\footnotetext{
${ }^{6}$ Esos treinta y cinco países fueron los siguientes: Andorra, Armenia, Austria, Azerbaiyán, Bosnia y Herzegovina, Croacia, República Checa, Dinamarca, Estonia, Georgia. , Alemania, Islandia, Letonia, Lituania, Luxemburgo (en parte), Malta, la República de Moldavia, Montenegro, los Países Bajos (también en relación con los territorios de Aruba y de Curaçao), Macedonia del Norte (todavía llamada antigua República Yugoslava de Macedonia en el momento de adopción de las conclusiones), Noruega, Polonia, Rumania, la Federación Rusa, Serbia, la República Eslovaca, España, Suecia, Turquía, Ucrania y el Reino Unido. Un Estado Parte (Albania) no presentó su informe y el informe de Hungría y la parte del informe de Luxemburgo sobre el artículo 6 CSE no pudieron ser examinados porque no se presentaron a tiempo.
} 
conclusiones se publicaron en marzo de 2019. Las principales conclusiones alcanzadas pueden resumirse del siguiente modo.

En cuanto al derecho a condiciones de trabajo justas reconocido en el artículo 2 CSE, el CEDS apreció vulneraciones de su apartado 1 en lo que respecta a la duración razonable del trabajo diario y semanal, observando que las horas de trabajo semanales de ciertas categorías de trabajadores (por ejemplo, trabajadores de los servicios de salud o empleados asignados a la vigilancia de la maquinaria o la protección de las mercancías) pueden elevarse a más de sesenta en España, Chipre, Noruega, los Países Bajos o Turquía; por otro lado, el personal del mar puede trabajar hasta setenta y dos horas a la semana en Islandia o Estonia. Todo lo cual es excesivo y, por lo tanto, contrario a la CSE. Es cierto que en algunos Estados se ha introducido una mayor flexibilidad en la organización del tiempo de trabajo (con semanas laborales más largas en ciertas épocas, compensadas por semanas más cortas en otras), una flexibilización que no es en principio disconforme con la CSE si se verifican ciertos criterios jurisprudenciales sentados por el CEDS para evitar la superación de unos máximos diarios y semanales, la imposición unilateral por parte del empleador o la utilización de períodos de referencia excesivamente laxos para el cómputo. Dicho lo cual, el CEDS ha concluido que semejante flexibilidad era excesiva en determinados supuestos en Turquía o en España, pudiendo llegar a superarse las setenta horas semanales mediante algunas fórmulas flexibles.

Por lo demás, en el marco del propio apartado 1 del artículo 2 CSE, el CEDS ha declarado su violación en lo atinente al régimen de guardias localizadas en países como Islandia, Polonia, Serbia y Eslovenia, al asimilarse dichas guardias cuando no se realiza un trabajo efectivo con períodos de descanso; por el contrario, es conocida la jurisprudencia del CEDS según la cual las guardias localizadas en las que no se produce un trabajo efectivo, si bien no pueden equipararse a tiempo de trabajo real, tampoco cabe asimilarlas a tiempo de descanso. Desde la perspectiva del derecho a días festivos pagados reconocido por el apartado 2 del artículo 2, el CEDS constató que existe en la generalidad de país con la excepción notoria del Reino Unido, además de plantear problemas en cuanto a su compensación (insuficiencia del incremento del 50 al 75\%) en países como Bosnia y Herzegovina, Malta, los Países Bajos, Noruega y la República Eslovaca). Con respecto al derecho a vacaciones anuales pagadas de cuatro semanas como mínimo (apartado 3 del artículo 2), el CEDS concluyó que mediaba una violación en situaciones (Chipre, Luxemburgo, Países Bajos, España) en donde no todos los empleados pueden disfrutar por lo menos de dos semanas ininterrumpidas en el año de referencia.

En lo que atañe a los otros cuatro párrafos del artículo 2, el CEDS alcanzó las siguientes conclusiones: la eliminación de los riesgos inherentes a las ocupaciones peligrosas o insalubres (apartado 4) no es suficientemente satisfactoria en términos de prevención en Bosnia y Herzegovina o Armenia, o no contempla medidas compensatorias apropiadas (como una reducción en las horas de trabajo o vacaciones pagadas adicionales) en países como Luxemburgo, Países Bajos o Reino Unido). Por su lado, la mayor parte de los incumplimientos del apartado 5 (descanso semanal) se debieron a un aplazamiento excesivo del disfrute de dicho reposo o a la ausencia de garantías suficientes para evitar 
trabajar más de 12 días consecutivos (República Checa, Georgia, Países Bajos, Federación de Rusia, ex República Yugoslava de Macedonia, Reino Unido o Ucrania). En lo atinente al derecho de los trabajadores a la información escrita desde el inicio de su empleo acerca de los aspectos esenciales de su contrato (apartado 6), únicamente ha planteado problemas en Bosnia y Herzegovina (en donde el Código de Trabajo de la República Srpska no contempla tal derecho). En fin, la ausencia de obligación de someter a todas las personas que realizan trabajo nocturno a un examen médico gratuito siguió siendo la razón principal del incumplimiento del apartado 7 en algunos Estados (Andorra, Bosnia y Herzegovina, Georgia, Moldavia, Serbia y Ucrania).

Por su parte, el respeto del derecho a una remuneración equitativa del artículo 4 CSE ha resultado controvertido en algunas Partes Contratantes en lo que afecta a sus apartados 1 a 3 . El apartado 1 (derecho a una remuneración suficiente que asegure a los trabajadores y sus familias un nivel de vida decoroso) es evaluado por el CEDS tomando como referencia el 50\% del salario medio neto y, a tal efecto, considera el baremo del $60 \%$ de ese salario como identificador de situaciones de "bajo salario" (excepto si, en la franja entre 50 y $60 \%$ el Estado demuestra que se asegura de algún modo ese nivel de vida decente); lo cual ha llevado a detectar la insuficiencia del salario mínimo en países como Andorra, Azerbaiyán, España, Lituania, Malta, Países Bajos, Rumania, Reino Unido y Serbia), incluso en el sector público, en donde el CEDS observó que siguen existiendo problemas para el personal contratado (España). Por su lado, el derecho de los trabajadores a un incremento de remuneración para las horas extraordinarias (artículo 4.2 CSE) no ha sido respetado en diversos países que no garantizan en su caso un tiempo compensatorio en lugar del pago de horas extras (Armenia, Estonia, República Checa, España, Países Bajos, Eslovaquia, Turquía, Polonia, ex República Yugoslava de Macedonia o Reino Unido). A continuación, el derecho de trabajadores y trabajadores a una remuneración igual por un trabajo de igual valor (artículo 4.3) se enfrenta con la realidad de una brecha salarial: en concreto, para los países que tienen reclamaciones colectiva pendientes por denuncias de dicha disposición, el CEDS se ha remitido a la resolución de ellas, mientras en otros casos ha constatado la no conformidad debido a la inexistencia de disposiciones legislativas que asegurar la igualdad salarial (Georgia), a la limitación de la indemnización al verificarse la discriminación (Armenia), a la imposibilidad de readmisión tras despido abusivo motivo por reivindicación de igualdad salarial (Finlandia), la no previsión de la inversión de la carga de la prueba en dichos litigios (Federación Rusa y Ucrania), a la ausencia de transparencia salarial y no autorización de comparaciones de salarios entre empresas en el sector privado (Moldavia), o a la existencia todavía de una brecha salarial entre mujeres y hombres superior al 25\% (Armenia, Azerbaiyán y Estonia).

Un tercer bloque jurisprudencial tiene que ver con los derechos laborales de ejercicio colectivo, es decir, la libertad sindical (artículo 5 CSE) y la negociación colectiva (artículo 6 CSE). En cuanto al derecho de sindicación, el CEDS ha estimado que en algunos países queda vulnerado por el hecho de exigir un excesivo número mínimo 
de miembros para la formación de sindicatos y organizaciones de empleadores (Armenia, Letonia y Serbia). En otros supuestos, la no conformidad con dicho precepto deriva del hecho de que la libertad de no afiliarse a un sindicato (dimensión negativa) no está suficientemente protegida (Islandia). El Comité ha encontrado asimismo en varios casos restricciones excesivas en cuanto al ámbito personal del derecho de sindicación (por ejemplo, el personal de la policía (Armenia, Azerbaiyán, República Checa, Georgia y Moldavia). Las injerencias que afectan a la autonomía de los sindicatos también fueron problemáticas en un Estado (Reino Unido).

En lo que atañe a la negociación colectiva, la problemática del respeto del artículo 6 CSE no ha derivado tanto de favorecer la consulta paritaria entre trabajadores y empleadores (apartado 1), sino de los otros aspectos previstos en dicha disposición, esto es: de un lado, la promoción de procedimientos de negociación voluntaria entre organizaciones de empleadores y de trabajadores con objeto de regular las condiciones de empleo por medio de convenios colectivos (apartado 2) no ha sido satisfactoria en Armenia, Azerbaiyán, República Checa, Estonia, Georgia, Letonia y Lituania, mientras que en España la violación de dicha disposición se debe a que la legislación habilitaba a los empleadores para que unilateralmente decidan la inaplicación de condiciones pactadas en convenios colectivos. De otro lado, el fomento de procedimientos de conciliación y arbitraje voluntarios para solucionar conflictos laborales (apartado 3) no ha sido observado en países como Malta y Moldavia, a causa de la imposición del arbitraje obligatorio en circunstancias que van más allá de la excepcionalidad prevista por el artículo $\mathrm{G}$ de la Carta (restricciones guiadas por el principio de proporcionalidad y que sean necesarias en una sociedad democrática para la garantía de los derechos y libertades de terceros o para proteger el orden público, la seguridad nacional, la salud pública o las buenas costumbres). En este mismo contexto, se ha vulnerado el derecho a emprender acciones colectivas, incluido el derecho de huelga (apartado 4), por la restricción a determinados sectores como la policía (Armenia, Malta o Moldavia), la administración penitenciaria (República Checa), el funcionariado en general (Alemania, Azerbaiyán, Dinamarca o Ucrania), o los que ostentan autoridad (Estonia), otros sectores como energía, telecomunicaciones o transportes (Armenia, Azerbaiyán, Bosnia y Herzegovina, Federación Rusa, Georgia, Moldavia, República Eslovaca, Serbia o Ucrania); se ha reprochado asimismo por el CEDS la infracción del artículo 6.4 a causa de la existencia de requisitos excesivos de convocatoria de una huelga (Alemania, Armenia, Federación Rusa, Reino Unido, República Checa y Rumanía), así como otras situaciones contrarias dicha disposición derivadas de la intervención de los poderes políticos para poner fin a acciones colectivas (en Islandia por imposición del Legislador, o la habilitación legislativa al Gobierno para imponer arbitraje obligatorio en España más allá de las restricciones previstas por el artículo 31 de la Carta de 1961 -equivalente al artículo G de la Carta revisada de 1996).

Otro bloque jurisprudencial relevante tiene que ver con la implicación de los trabajadores y sus representantes en el seno de la empresa. Así, en el caso de la 
información y consulta (artículo 21 CSE), el CEDS ha evaluado más de una veintena de situaciones nacionales, con un grado de cumplimiento bastante generalizado. A tal efecto, el CEDS atribuye relevancia a los datos sobre intervenciones o visitas de la inspección laboral y eventuales sanciones impuestas a los empleadores, requiriendo a los Estados Partes para que los aporten y, en consecuencia, determinando el aplazamiento de dicha disposición en caso contrario (por ejemplo, en ex República Yugoslava de Macedonia y en Serbia), o llegando a concluir una violación cuando un país omite reiteradamente facilitar la información requerida por el CEDS (Bosnia y Herzegovina). Por otra parte, en el supuesto de la participación de los empleados en la determinación y mejora de las condiciones laborales (artículo 22 CSE), el CEDS examinó 20 situaciones nacionales, concluyendo la conformidad en catorce países. En tres casos (Croacia, Letonia y Turquía), la conclusión se ha aplazado, por cuanto los países afectados no proporcionaron la información suficiente requerida por dicha disposición. En cambio, determinó la no conformidad con respecto a tres países (Azerbaiyán, Bosnia y Herzegovina y Serbia), dado que los empleados no disfrutaban de un derecho efectivo para participar en el proceso de toma de decisiones dentro de la empresa con respecto a las condiciones de trabajo, la organización del trabajo y el entorno laboral, ni de vías efectivas de recurso al efecto.

Como parte integrante de este mismo bloque jurisprudencial, el CEDS ha analizado: de un lado, el derecho de los representantes de los trabajadores a protección y facilidades en la empresa (artículo $28 \mathrm{CSE}$ ). A tenor de dicha disposición, todas las formas de representación de los trabajadores, y no solo los sindicatos, deben gozar de los derechos garantizados por ella. En virtud de la CSE, para que sea efectivo, el alcance de la protección ofrecida a los representantes de los trabajadores debe extenderse por un período de tiempo razonable (al menos seis meses según la jurisprudencia del CEDS) después de la expiración de su mandato. Los motivos más frecuentes del incumplimiento del artículo $28 \mathrm{CSE}$ fueron precisamente la falta de protección al vencimiento del mandato (Austria, Azerbaiyán, Bosnia y Herzegovina, ex República Yugoslava de Macedonia, Lituania, Noruega, Rumania, Rusia o Turquía), o diversas formas de acoso o maltrato a dichos representantes (Azerbaiyán, Armenia, Turquía, Ucrania, Moldavia, y ex República Yugoslava de Macedonia), o falta de protección adecuada frente al despido (Ucrania). En su jurisprudencia, el Comité proporciona ejemplos de facilidades a otorgar a los representantes de los trabajadores, tales como la provisión de locales y material de oficina, la autorización para difundir informaciones o la concesión de asistencia financiera, aspectos no respetados en Armenia, Bosnia y Herzegovina, Moldavia, Rumania, ex República Yugoslava de Macedonia y Rusia. De otro lado, el CEDS ha analizado el derecho a información y consulta que debe preceder a los procedimientos de despido colectivo (art. 29 CSE), cuyo respeto es prácticamente mayoritario, con la excepción notoria de Georgia y de Azerbaiyán (que no garantizan el derecho a la consulta en tiempo y forma con anterioridad a la decisión de despedir). 
El último bloque jurisprudencial esencial se ha centrado en el artículo 26 CSE, que garantiza el derecho a la dignidad en el trabajo. De conformidad con los apartados 1 y 2 de dicha disposición, los Estados deben tomar todas las medidas necesarias en materia de prevención y reparación para proteger a los trabajadores contra el acoso, sexual y moral. En particular, incurre en responsabilidad el empleador en caso de acoso que involucre a sus empleados o cuando dichas acciones se cometan en las instalaciones de las que es responsable, incluso por parte de terceros. Las víctimas de acoso deben poder apelar ante un organismo independiente para obtener una reparación, y la legislación civil debe prever una inversión de la carga de la prueba. Los recursos legales efectivos deben incluir una compensación adecuada para cubrir daños materiales y morales y, cuando corresponda, la readmisión de las víctimas a su puesto, incluso cuando hayan renunciado debido al hostigamiento. Sobre la base de estos criterios, el CEDS consideró que, en varios países, los asalariados no gozaban de una protección adecuada contra el acoso sexual (Azerbaiyán, Georgia, Lituania, Ucrania) o el acoso moral (Azerbaiyán, Georgia, Lituania, Malta, Ucrania). En la mayoría de los casos, sin embargo, esta conclusión fue motivada por la falta de información relevante en respuesta a las preguntas formuladas anteriormente.

\subsection{EI lado positivo: progresos significativos constatados y cautelas interpretativas}

La publicación de las Conclusiones relativas a 2018 no se ha limitado a "señalar" o "sacar los colores" a los Estados por sus incumplimientos de la Carta Social, sino que ha incluido una serie de evoluciones positivas que dan cuenta, durante el período de referencia analizado, del efecto útil del Pacto Europeo de Derechos Sociales por excelencia, ya sea a través de la adopción de nuevas normas o de la producción de cambios en la práctica.

En cuanto al derecho a condiciones de trabajo justas (artículo 2 CSE), en la Bosnia y Herzegovina se adoptaron a principios de 2016 sendos nuevos Códigos de Trabajo en la Federación de Bosnia y Herzegovina y en la República Srpska, con mejora de las condiciones del disfrute del derecho a vacaciones anuales pagadas; en dicho terreno (con la explícita garantía de no renuncia a tal derecho) y en el del descanso semanal, se había verificado asimismo una modificación (con vigencia desde julio de 2014) en el Código de Trabajo de Serbia. Se constataron también mejoras en la legislación de la Federación de Rusia adoptada a finales de 2013 y principios de 2014 en materia de eliminación de los riesgos inherentes a las ocupaciones peligrosas o insalubres, así como en Macedonia del Norte (enmienda en 2016 de la Ley de Seguridad y Salud Ocupacional). En Eslovenia se verificaron, mediante la nueva Ley de Relaciones Laborales (entrada en vigor en 2014), progresos en lo atinente a los elementos obligatorios de un contrato de trabajo, que se extienden incluso a la razón para el empleo temporal en un contrato de duración determinada.

En lo concerniente al derecho a una remuneración equitativa del artículo 4 CSE, 
en Austria se modificó en 2016 la legislación sobre el personal docente de las escuelas privadas, para mejorar la remuneración básica por hora y la compensación por horas extraordinarias, mientras en Islandia se aumentó gradualmente durante el período de referencia el montante del salario mínimo, o en Montenegro se suscribió en 2014 un acuerdo general entre el Gobierno y los interlocutores sociales para el incremento significativo (de, al menos, un 40\%) de la remuneración por horas extraordinarias.

Los avances sobre el derecho de sindicación (artículo 5 CSE) han pasado por la nueva legislación luxemburguesa aprobada el 23 de julio de 2015 (que suprimía la condición de nacionalidad de un Estado miembro de la UE para ser candidato a miembro de comités de empresa), o la adopción el 6 de marzo de 2014 de una nueva ley sobre libertad sindical en el Parlamento de Letonia. Por lo que se refiere a la negociación colectiva (artículo 6 CSE), en Países Bajos se levantaron, a través de la nueva legislación aprobada el 3 de diciembre de 2014, las restricciones al derecho de huelga que todavía afectaban a funcionarios públicos.

En el ámbito de la información y consulta prevista por el artículo 21 CSE, se produjeron mejoras en Croacia mediante la nueva Ley del Trabajo 93/2014; en Países Bajos se modificaron durante el período de referencia las normas sobre los comités de empresa (en aspectos tales como la capacitación de los miembros de dichos comités y los costes de tal capacitación, o la comunicación de los representantes de los trabajadores con la empresa matriz en el extranjero de empresas holandesas que formen parte de un grupo internacional), y en la Federación se aprobó el 7 de mayo de 2013 una ley estableciendo en el Código del Trabajo un nuevo sistema de consulta de los empleados sobre productividad y mejora de las habilidades o la capacitación en el empleo. Por otro lado, en el caso de la participación de los empleados en la determinación y mejora de las condiciones laborales (artículo 22 CSE), se subrayan por el CEDS los avances propiciados en Dinamarca mediante una nueva estrategia (hasta 2020) tendente a reducir el número de accidentes graves o de empleados con sobrecarga psicológica, así como la entrada en vigor de nueva legislación en Eslovenia (Ley de relaciones laborales $n^{\circ}$ 21/2013).

Por su lado, la garantía del derecho a la dignidad en el trabajo del artículo 26 CSE ha venido favorecida en Andorra (con la creación de un servicio especializado que proporciona asistencia transversal -social, psicológica y legal- a las mujeres víctimas de acoso sexual, o la modificación en abril de 2015 del Código Penal para perfilar la definición de tal acoso sexual), en Lituania (con la introducción en el nuevo Código de Trabajo, con vigencia desde julio de 2017 -fuera del período de referencia en este casode una disposición que prohíbe expresamente el acoso moral), en Moldavia (enmiendas legislativas en abril de 2016 para que los empleadores informen explícitamente a los empleados sobre la prohibición de todos los actos de discriminación y acoso en el trabajo, con la eventual obligación de informar a la policía), en Macedonia del Norte (nueva Ley de Protección contra el Acoso en el Lugar de Trabajo, aprobada en 2013, que refuerza el 
papel de la inspección de trabajo en este ámbito), en Turquía (con la adopción en 2014 de directrices sobre acoso moral en el trabajo por parte del Ministerio de Trabajo y Seguridad Social, o una definición más minuciosa del acoso psicológico y moral en el trabajo en la nueva legislación vigente a partir de abril de 2016) o en Ucrania (con la publicación en el período de referencia de una manual para empleadores titulado "Respeto del principio de igualdad de trato y no discriminación en el trabajo en los sectores público y privado en Ucrania", que incluye recomendaciones sobre qué hacer ante una queja).

En fin, se resalta por el CEDS la nueva Ley de empleo adoptada asimismo en Ucrania durante el período de referencia con objeto de mejorar los derechos contemplados en los artículos 28 y 29 CSE, en especial, la obligación que pesa sobre el empleador de consultar a los sindicatos y tomar medidas para prevenir y limitar el impacto negativo de los despidos colectivos.

Por lo demás, una vez dado cuenta de ese balance positivo, el CEDS incorporó una serie de cautelas interpretativas bajo dos modalidades. La primera de ellas, el planteamiento de varias preguntas a los Estados Partes, en este caso para limitar el alcance de las restricciones susceptibles de afectar a los derechos de sindicación y de negociación colectiva (artículos 5 y 6 CSE): así, recordó que las restricciones a la libertad sindical de las fuerzas armadas previstas por el artículo 5 no deben ser absolutas (para no suprimir completamente el ejercicio de tal derecho (las asociaciones que representan a los ejércitos deberían poder, bajo ciertas condiciones, unirse a organizaciones profesionales nacionales); o, con respecto a la policía, el CEDS esgrimió que una prohibición absoluta del derecho de huelga solo puede ser conforme al artículo $6 \$ 4$ si existen razones de peso para hacerlo. En este último contexto, el CEDS ha solicitado a los Estados Partes que proporcionen información sobre el derecho de huelga de los agentes de policía y cualquier restricción que se le pueda imponer. De igual manera, el CEDS formuló una pregunta general sobre la aplicación de restricciones a los trabajadores por cuenta propia a la luz del artículo $6 \$ 2$, de tal suerte que una prohibición absoluta de la negociación colectiva que afectara a todas las personas que trabajan por cuenta propia sería excesiva, ya que tal medida sería contraria al objeto y propósito de dicha disposición (se remite así a la decisión de fondo de 12 de septiembre de 2018 sobre la Reclamación colectiva $\mathrm{n}^{\circ}$ 123/2016, Irish Congress of Trade Unions, ICTU c. Irlanda, párrafos 37-40). En suma, el Comité solicitó a los Estados partes que proporcionen información sobre las medidas adoptadas o previstas para garantizar el derecho de negociación colectiva de los trabajadores por cuenta propia y otros trabajadores que no están comprendidos en la definición habitual de trabajadores dependientes.

Por último, la segunda de las cautelas exegéticas vino dada por la recuperación de la técnica de las observaciones interpretativas (que había sido desafortunadamente abandonada en las Conclusiones 2017), formulando concretamente una observación sobre el artículo $4 \$ 4$ (derecho a un plazo de preaviso razonable en caso de terminación del empleo). En ella indicó el CEDS que la cuestión de la razonabilidad de los períodos de preaviso ya no será examinada en detalle sobre la base principal de los criterios que 
establecen duraciones variables según las circunstancias específicas. De tal manera que un plazo de aviso razonable será apropiado cuando tenga en cuenta la antigüedad del trabajador, la necesidad de no privar abruptamente al trabajador de su sustento y la necesidad de informar al trabajador en tiempo útil para que pueda buscar un nuevo empleo. Durante este período, el trabajador tiene derecho a una remuneración normal. Corresponde a los gobiernos demostrar que estos elementos se han tenido en cuenta en la concepción y la aplicación de las normas básicas en materia de duración del preaviso. El CEDS también se muestra especialmente preocupado por la situación de los trabajadores afectados por relaciones laborales precarias.

\section{La situación española ${ }^{7}$}

Del grupo temático III (derechos laborales) sometido a examen en 2018 [recordemos, artículos 2, 4, 5, 6, 21 (equivalente al artículo 2 del Protocolo de 1988), 22 (equivalente al artículo 3 del Protocolo de 1988), 26, 28 y 29], las tres últimas disposiciones mencionadas (pese a versar sobre aspectos fundamentales, como el derecho a la dignidad en el trabajo -que cubre la prevención y protección frente al acoso sexual y moral-, el derecho de los representantes de los trabajadores a protección y facilidades en el seno de la empresa, o el derecho a información y consulta en los procedimientos de despido colectivo, respectivamente) no han sido objeto de examen con relación a España, al no haber aceptado nuestro país el tratado revisado de 1996. ¿Cuál es el balance, entonces, de ese grupo III sobre derechos laborales, de la jurisprudencia del CEDS con respecto a España en 2018 [Conclusiones XXI-3 (2018)]?

De entrada, cabe recordar que la fecha límite para la presentación del $30^{\circ}$ informe era el 31 de octubre de 2017 y España la presentó el 14 de noviembre de 2017. El período de referencia era del 1 de enero de 2013 al 31 de diciembre de 2016. Pues bien, se han examinado diecisiete situaciones, habiendo arrojado la evaluación del CEDS el siguiente resultado: ha apreciado ocho casos de conformidad (artículos 2§2, 2§5, 4§3, $4 \S 5,5,6 \S 1$ y los artículos 2 y 3 del Protocolo adicional) y siete conclusiones de no conformidad (artículos $\mathbf{2} \mathbf{1}, \mathbf{2} \$ 3, \mathbf{4} \$ 1,4 \$ 2,4 \$ 4,6 \$ 2$ y 6\$4) además de aplazar o diferir el examen de dos supuestos (artículos $2 \S 4$ y $6 \S 3$ ) ante la falta de información suficiente suministrada por las autoridades españolas; el CEDS necesita entonces información adicional para poder evaluar ambas situación. Así, el CEDS considera que la falta de información solicitada constituye un incumplimiento de la obligación de información de España en virtud de la Carta de 1961, requiriendo a las autoridades españolas para que remedien esta situación y suministren dicha información en el próximo informe.

Avanzada esta breve síntesis, resulta del mayor interés, lógicamente, referirse a

\footnotetext{
${ }^{7}$ Un magnífico balance de estas conclusiones 2018 referentes a España, en el trabajo de SALCEDO BELTRÁN, C.: "Crónica Europea. Conclusiones XXI-3 (2018) del Comité Europeo de Derechos Sociales: Evidencias de la «indiferencia» y «resistencia» a la Carta Social Europea", Derecho de las Relaciones Laborales, $\mathrm{n}^{\circ}$ 5, 2019, pp. 541-552.
} 
los siete casos de violación; de los cuales, seis de ellos (artículos $2 \S 1,4 \S 1,4 \S 2,4 \S 4,6 \S 2$ y 6\$4) ya tuvieron un diagnóstico negativo en las precedentes conclusiones, tanto de 2014 como ya de 2010 (que cubrieron el período de referencia 1 de enero de 2005 a 31 de diciembre de 2008); ahora bien, en un par de casos, la desfavorable coincidencia no deriva sencillamente de un "mal endémico" del sistema laboral y sindical español, sino que se ha visto agravada por la legislación anticrisis (artículos $4 \S 4$ y 6\$4). Para alcanzar las conclusiones negativas, el CEDS tomó en consideración como elementos valiosos la observaciones y denuncias formuladas por CCOO y UGT el 27 de abril de 2018, además de la respuesta gubernamental española a dichos elementos de contradicción (respuesta de fecha 27 de junio de 2018).

Las dos primeras conclusiones negativas comprenden sendas violaciones del artículo 2, que reconoce el derecho a unas condiciones de trabajo equitativas.

En concreto, España ha incumplido lo dispuesto en el apartado 1 de dicha disposición, que obliga "a fijar una razonable duración diaria y semanal de las horas de trabajo, reduciendo progresivamente la semana laboral en la medida en que lo permitan el aumento de la productividad y otros factores pertinentes"; el motivo de vulneración radica en "que la duración máxima del trabajo puede ser superior a las 60 horas semanales en el marco de fórmulas flexibles de organización del tiempo de trabajo y para algunas categorías de trabajadores". Para alcanzar semejante conclusión, el CEDS constata que siguen sin realizarse modificaciones en el Estatuto de los Trabajadores, que prevé un descanso obligatorio de doce horas entre dos días laborables consecutivos y un día y medio de descanso semanal ininterrumpido acumulable durante 14 días, lo que podría conducir a un tiempo de trabajo semanal superior a 60 horas.

Por desgracia, nos encontramos ante una conclusión de no conformidad con el artículo $2 \$ 1 \mathrm{CSE}$ que no ha sido corregida con respecto a análisis anteriores (entre otras, en las anteriores conclusiones de 2010 referidas al período 1 de enero de 2005 a 31 de diciembre de 2008 o en las conclusiones de 2014 relativas al período 1 de enero de 2009 a 31 de diciembre de 2012), en los que el CEDS ya constató dicha violación, al autorizar el Estatuto de los Trabajadores (particularmente, su artículo 34) esas fórmulas flexibles, especialmente para el personal médico-sanitario. El CEDS trae a colación efectivamente las precedentes conclusiones en las que recordó que la redacción introducida en el artículo 34 del Estatuto de los Trabajadores mediante el Real Decreto-ley 3/2012, de 10 de febrero, de medidas urgentes para la reforma del mercado laboral y la posterior Ley 3/2012, de 6 de julio, tampoco habían solucionado el problema. A este respecto, el CEDS reitera su jurisprudencia en torno a la posibilidad de adoptar medidas de flexibilidad en el mercado laboral, pero siempre que respeten igualmente criterios como que la jornada o el tiempo semanal de trabajo no sea irrazonable, que exista una marco normativo con garantías suficientes para empleadores y trabajadores, y que se prevean períodos de referencia razonables que no superen generalmente los seis meses, y sólo de manera muy excepcionalmente el año (alude una vez más a la decisión de fondo de 16 de noviembre de 2001 relativa a la reclamación $n^{\circ}$ 9/2000, Confédération française de l'encadrement CFE-CGC c. Francia, párrafos 29 a 38). Por consiguiente, se impone una modificación 
legislativa para corregir dicha vulneración de la CSE por el Estatuto (artículo 34), pese a que el CEDS observe que al parecer se trata más bien de un problema de legislación que de praxis (de hecho, no habría sido puesto de manifiesto por la inspección de trabajo), puesto que el CEDS controla la adecuación a la Carta Social tanto de la práctica como del marco normativo. Por lo demás, el CEDS vuelve a expresar sus cautelas con relación a la regulación y la práctica de las guardias localizadas en España a efectos de verificar que no se produce una asimilación entre tiempo de trabajo y tiempo de descanso, requiriendo información sobre el particular al Gobierno para el próximo ciclo de control.

Particularmente, con respecto al marco legal específico que regula los acuerdos flexibles de tiempo de trabajo, el CEDS renueva la cuestión sobre cuántas veces el empleador, en ausencia de un convenio colectivo, toma la decisión unilateral de redistribuir el 10\% de las horas de trabajo. Por otra parte, dado que el Estatuto de los Trabajadores seguía previendo, como regla general, períodos de referencia de un año, interroga otra vez al Gobierno sobre el régimen a que quedan, de hecho, sometidos los trabajadores que han aceptado acuerdos de tiempo de trabajo con largos períodos de referencia, para comprobar que no están sujetos a horarios de trabajo irrazonables o tiempos laborales semanales excesivos.

Por su lado, la conclusión de no conformidad al artículo $\mathbf{2} \$ \mathbf{3}$ (a tenor del cual los Estados Partes tienen la obligación de "conceder vacaciones anuales pagadas de dos semanas como mínimo", en la versión originaria de la CSE de 1961 aceptada por España, que es mejorada en la versión revisada de 1996 extendiendo tal obligación a cuatro semanas como mínimo) se redacta en los siguientes términos por el CEDS: "la situación de España no es conforme al artículo $2 \$ 3$ de la Carta de 1961, dado que todos los empleados no tienen derecho a coger por lo menos dos semanas de vacaciones pagadas ininterrumpidas durante el año". Para llegar a tal veredicto negativo el CEDS constata que, según el informe gubernamental, las vacaciones anuales pagadas en España deben tomarse por franjas de un mínimo de cinco días hábiles ininterrumpidos.

El segundo bloque de conclusiones negativas se refiere al artículo $4 \mathrm{CSE}$, que reconoce el derecho a una remuneración equitativa. Cabe lamentar que la vulneración de tres de sus apartados (1, 2 y 4) no es una novedad, pues como se apuntaba también en las conclusiones de 2010 y de 2014 se verificaron esas mismas tres violaciones, que en el caso del artículo 4.4 se han visto acentuadas por la legislación anticrisis más reciente a tenor de la apreciación del CEDS.

Así, si en 2010 la infracción del artículo 4 \$1 CSE consistió “en que el salario mínimo es manifiestamente injusto" y en las conclusiones correspondientes a 2014 se retomó la apreciación del CEDS de manera desglosada (considerando que "el salario mínimo de los trabajadores del sector privado resulta insuficiente para asegurar un nivel de vida decente" y que "el salario mínimo del personal contratado en la función pública resulta insuficiente para asegurar un nivel de vida decente"), en las conclusiones de 2018 se reproduce exactamente esa misma fórmula negativa detallada de 2014 . 
El CEDS se sigue apoyando en este terreno en los datos comparativos facilitados por EUROSTAT. En realidad, se trata de una conclusión sobre el carácter insuficiente e injusto del salario mínimo que viene constatándose desde 1998. En las conclusiones precedentes de 2014, se llamó la atención por el CEDS sobre la congelación de dicho salario mínimo a la luz de las preocupaciones expresadas asimismo por el Comité de Derechos Económicos, Sociales y Culturales de la ONU en sus observaciones finales de 6 de junio de 2012, percibiéndose en este último caso las sinergias entre el sistema europeo y el sistema universal. En las presentes conclusiones de 2018, se toma nota de las modestas subidas progresivas del salario mínimo interprofesional (SMI) durante el período de referencia (entre 645,30€ para 2013 y 655,20€ para 2016), reprochando en cambio que el Gobierno no haya facilitado informaciones concretas sobre el valor neto del SMI y del salario medio (a efectos comparativos, comprobando el CEDS a tenor de la base de datos de EUROSTAT que el SMI se situaba al 34,10\% del salario medio).

Como es conocido, el SMI ha sido una de las cuestiones "estrella" de la confrontación política en el terreno social, habiéndose elevado a 900€/mes para 2019 (tras acuerdo alcanzado entre PSOE y Podemos) mediante el Real Decreto 1462/2018, de 21 de diciembre, en cuyo texto preambular se contienen estas interesantes referencias explícitas a la jurisprudencia del CEDS y a los ODS, que conviene transcribir:

"El citado incremento atiende a la mejora de las condiciones generales de la economía y tiene como objetivo prevenir la pobreza en el trabajo y fomentar un crecimiento salarial general más dinámico. Para ello y en línea con las recomendaciones internacionales, para garantizar el ejercicio efectivo del derecho a una remuneración equitativa y reconocer el derecho de los trabajadores a una remuneración suficiente que les proporcione a ellos y a sus familias un nivel de vida decoroso, el Comité Europeo de Derechos Sociales ha interpretado que dicho umbral se sitúa en el $60 \%$ del salario medio de los trabajadores. Elevar el salario mínimo interprofesional a 900 euros mensuales nos acerca a dicha recomendación.

Por último, la subida del salario mínimo interprofesional es un factor decisivo para que la creación de empleo y la recuperación económica se traduzcan en una progresiva reducción real de la pobreza en todas sus dimensiones y de la desigualdad salarial, ayudando a promover un crecimiento económico sostenido, sostenible e inclusivo, con lo que España contribuye al cumplimiento de la Agenda 2030, en particular de las Metas 1.2 y 10.4 de los Objetivos de Desarrollo Sostenible”.

Si esto es así para el sector privado, en el caso del funcionariado se solicita más información y se aplaza un diagnóstico (que el CEDS estima por el momento en torno al $50 \%$ del salario medio nacional neto, especialmente para los auxiliares y oficiales), mientras en el supuesto del personal contratado de la función pública el CEDS reproduce la reseñada conclusión negativa ante la falta reitera de información. Por lo demás, el CEDS vuelve a solicitar informaciones sobre la remuneración mínima aplicable a los trabajadores autónomos económicamente dependientes a la luz de los artículos 11 y siguiente de la Ley 20/2007, de 11 de julio, del Estatuto del trabajo autónomo.

Algo similar sucede con la conclusión de violación del artículo 4 \$2 CSE, en este 
caso dirigiéndose el reproche otra vez a la legislación, por cuanto "el Estatuto de los Trabajadores no garantiza un aumento salarial o un descanso compensatorio adicional por las horas extraordinarias"; la redacción de esta conclusión de 2018 es análoga a las de 2010 y de 2014. A tal efecto, el CEDS vuelve a observar que el artículo 35 del Estatuto de los Trabajadores simplemente permitía a las partes establecer mediante la negociación colectiva el incremento salarial y las condiciones de descanso compensatorio. Sin embargo, el Estatuto se limitar a prever, en el apartado 1 del citado artículo 35 que "mediante convenio colectivo o, en su defecto, contrato individual, se optará entre abonar las horas extraordinarias en la cuantía que se fije, que en ningún caso podrá ser inferior al valor de la hora ordinaria, o compensarlas por tiempos equivalentes de descanso retribuido. En ausencia de pacto al respecto, se entenderá que las horas extraordinarias realizadas deberán ser compensadas mediante descanso dentro de los cuatro meses siguientes a su realización”. Para el CEDS, en suma, dicha previsión legal no garantiza lo dispuesto por el artículo $4 \S 2$ y la jurisprudencia de aquél, solicitando al Gobierno español precisiones sobre la situación del sector privado en materia de horas extraordinarias, acompañadas por datos que procedan de los servicios de la inspección laboral, dado el mayor esfuerzo que requieren por parte del trabajador la realización de dichas horas.

Como se anticipada, la tercera conclusión conculcadora del artículo 4 CSE de 1961 se refiere a su apartado 4 (obligación de los Estados Partes de "reconocer el derecho de todos los trabajadores a un plazo razonable de preaviso en caso de terminación del empleo"), y se basa en los dos motivos siguientes: “- El plazo de preaviso de dos semanas no es razonable para los trabajadores con más 6 meses de antigüedad; -en caso de incapacidad o muerte del empleador, no hay plazo de preaviso o para trabajadores en período de prueba". El CEDS llega a dicha doble conclusión tras iniciar su razonamiento recordando explícitamente la triple conclusión vulneratoria alcanzada en las conclusiones de 2014, que se basó entonces en los siguientes motivos: de un lado, "el plazo de preaviso aplicable a los contratos indefinidos y de duración determinada no es razonable en las siguientes circunstancias: el despido cuando el contrato de trabajo ha expirado o sus objetivos se han realizado; la extinción del contrato de trabajo por deceso o jubilación del empleador persona física o por disolución del empleador persona jurídica, a partir de tres años de antigüedad; la extinción del contrato de trabajo por motivos objetivos, a partir de seis meses de antigüedad"; de otro lado, "el plazo de preaviso se excluye en el despido durante el período de prueba de los contratos de apoyo a emprendedores"; y, en tercer término, "el plazo de preaviso puede quedar a disposición de las partes en el contrato de trabajo". Cabe observar, no obstante, que la situación criticada por el CEDS se ha revertido parcialmente ya fuera del período de referencia evaluado, con derogación de la modalidad contractual controvertida (de apoyo a emprendedores), mediante el Real Decreto-ley 28/2018, de 28 de diciembre, para la revalorización de las pensiones públicas y otras medidas urgentes en materia social, laboral y de empleo.

En cualquier caso, en su Conclusión de 2018, el CEDS toma nota de las observaciones de CCOO y de UGT, en las que subrayan que nos encontramos ante 
cuestiones que aún no han sido resueltas por la legislación y las prácticas nacionales, y que a los trabajadores temporales se sigue sin garantizar un período mínimo de preaviso de terminación de la relación laboral; en otras palabras, la legislación laboral no habría corregido las deficiencias observadas previamente por el CEDS, por lo que persistiría la situación contradictoria con la Carta Social. De hecho, la doble conclusión violatoria constatada por el CEDS no se vio atemperada por estos otros argumentos hechos valer por el Gobierno, consistentes en las siguientes manifestaciones: para contratos temporales con una duración superior a un año, el plazo de preaviso es de un mínimo de quince días; en caso de extinción de la personalidad jurídica de la parte contratante, el período de preaviso es de quince días; en caso de extinción debida a fallecimiento, incapacidad o jubilación del empleador, no hay plazo de preaviso.

Finalmente, el bloque que completa las conclusiones negativas referentes a España tiene que ver con el derecho a la negociación colectiva (artículo 6 CSE), en concreto los apartados 2 y 4. Empezando por este último apartado, el CEDS reitera un diagnóstico desfavorable que viene de atrás, al concluir que "la situación de España no es conforme al artículo $\mathbf{6} \$ 4$ de la Carta de 1961 por cuanto la legislación autoriza al Gobierno a que imponga el arbitraje obligatorio para poner fin a una huelga en casos que van más allá de las derogaciones permitidas por el artículo 31 de la Carta de 1961"; este es, en efecto, el mismo tenor de las conclusiones precedentes alcanzadas en 2014, así como en 2010 y en 2006, si bien entonces se especificó en la misma conclusión la referencia a la legislación, con alusión concreta al artículo 10.1 del Decreto-Ley $n^{\circ} 7$ de 4 de marzo de 1977 sobre relaciones de trabajo.

Como es sabido, el artículo $31 \mathrm{CSE}$ se refiere a limitaciones "establecidas por la Ley y que sean necesarias en una sociedad democrática para garantizar el respeto de los derechos y libertades de terceros o para proteger el orden público, la seguridad nacional, la salud pública o las buenas costumbres". De este modo, el CEDS es más estricto al interpretar esas posibles restricciones al derecho de huelga que el Tribunal Constitucional español (que habría depurado insuficientemente el citado artículo 10.1 mediante su famosa Sentencia de 8 de abril de 1981); en su conclusión, el CEDS se refiere asimismo a un pronunciamiento del Tribunal Supremo español de 9 de mayo de 1988, en la éste habría "considerado que la situación debía presentar un carácter excepcional o debería haber circunstancias acumuladas, todas ellas puestas en conocimiento del Gobierno antes de que éste haga uso de su poder discrecional".

Por otro lado, la conclusión de violación del artículo 6\$2 CSE tiene el siguiente tenor literal: la situación de España no es conforme a tal disposición, por cuanto "la legislación permite a los empleadores, de manera unilateral, que no apliquen las condiciones acordadas en los convenios colectivos". En las Conclusiones precedentes de 2014 ese diagnóstico negativo ya estaba presente, pero se le añadía otro más; en concreto, en dichas Conclusiones se declaró cuatro años antes: "El Comité concluye que la situación de España no es conforme al artículo $6 \$ 2$ de la Carta de 1961 por estos motivos: la legislación que afecta al derecho a la negociación colectiva ha sido adoptada sin consultar 
a los sindicatos y a las organizaciones empresariales; la Ley 3/2012 permite a los empleadores de manera unilateral que no apliquen condiciones acordadas en convenios colectivos".

En las Conclusiones de 2018 el CEDS ha estimado que ese primer motivo vulneratorio habría sido corregido, tras constar que "se trataba de una situación excepcional que no parece haberse reproducido durante el período de referencia, aunque la legislación permanezca vigente". Esa excepcionalidad había sido reprochada por el CEDS en 2014 al no aceptar el argumento del Gobierno según el cual la urgencia de la situación (la crisis económica que golpeó al país a partir de 2008) exigía la adopción de legislación (del Decreto-Ley 3/2012, después convertido en Ley 3/2012) sin consulta, y haciéndose eco en cambio el CEDS de las consideraciones del Comité de la OIT sobre la libertad sindical (que había subrayado que las decisiones sobre los procedimientos de negociación deben ser tomadas a través del diálogo social).

Por lo que respecta al segundo motivo de violación declarado en 2014 (que constituye ahora en 2018 el único motivo de no conformidad), el CEDS recuerda que el panorama legislativo no se ha modificado durante el período de referencia, de tal suerte que la redacción del artículo 41 del Estatuto de los Trabajadores introducida mediante la Ley 3/2012 autorizó y ha seguido autorizando al empleador para que éste unilateralmente no aplique las condiciones laborales previamente pactadas a nivel de empresa. Para el CEDS, dicha Ley no definía suficientemente las bases para la inaplicación unilateral. En todo caso, el CEDS requiere al Gobierno español para que en el próximo informe proporcione informaciones detalladas sobre las circunstancias en las que un acuerdo de empresa puede derogar las condiciones pactadas mediante un convenio sectorial o nacional, así como sobre la proporción de trabajadores que están cubiertos por un convenio colectivo. Como es conocido, este es uno de los aspectos en los que, en el contexto de las promesas electorales sociales de los comicios generales celebrados en España el 28 de abril de 2019 y en clave de la manida derogación de la legislación de reforma del mercado laboral, más han incidido los sindicatos mayoritarios a nivel estatal y comparecientes en el sistema de informes (CCOO y UGT).

Sin lugar a dudas, la conclusión más llamativa de 2018 tiene que ver con el incumplimiento reiterado del artículo $4 \$ 4$ CSE. Como he venido insistiendo, la efectividad de las resoluciones del CEDS en España se refiere, directamente, a sus conclusiones emitidas en el marco del preceptivo sistema de informes (establecido en la CSE de $1961^{8}$ ), así como, indirectamente, a las decisiones sobre reclamaciones colectivas frente a otros países susceptibles de ser aplicadas a supuestos análogos en nuestro país. Por supuesto, el ejemplo más emblemático y mediático en España vino dado por la decisión de 23 de mayo de 2012 sobre la Reclamación no 65/2011 (GENOP-DEI y $A D E D Y$ c. Grecia), en la que se declaró una violación del artículo $4 \S 4$ CSE, por cuanto

\footnotetext{
${ }^{8}$ En las fichas por países (country factsheets/fiches par pays) publicadas en la web oficial de la CSE (www.coe.int/socialcharter) se incluye un apartado con "ejemplos de progresos realizados en el cumplimiento de los derechos reconocidos en la Carta Social". Enlace con la ficha relativa a España: https://rm.coe.int/spain-and-the-european-social-charter/1680492969 (último acceso 1 de julio de 2020).
} 
la ley nacional que autorizaba el despido sin preaviso ni indemnización a los asalariados con contrato de duración indefinida durante un período inicial de doce meses era incompatible con dicha disposición de la CSE. Como se recordará, en el plano judicial ordinario, algunos órganos jurisdiccionales españoles llegaron a ejercer el control de convencionalidad con apoyo explícito en esa decisión del CEDS de 23 de mayo de 2012 (Reclamación n ${ }^{\circ}$ 65/2011) para, haciendo valer la prevalencia de un tratado (a la sazón, la CSE) sobre la aplicación de la disposición (artículo 4.3) de la Ley 3/2012, de 6 de julio, de reforma del mercado de trabajo que estableció una figura contractual (contrato indefinido de apoyo a emprendedores) análogo a la griega (bajo impulso o presión de la Troika), descartar la aplicación de la disposición nacional. Esa postura la inauguró la Sentencia ${ }^{\circ}$ 412/2013, de 19 de noviembre de 2013, del Juzgado de lo Social $n^{\circ} 2$ de Barcelona (procedimiento $\mathrm{n}^{\circ} 426 / 2013$ en materia de despido) y ha sido seguida con diversa intensidad por otros órganos jurisdiccionales del orden social. Lo curioso es que, incluso tras la STC 119/2014, de 16 de julio (que avaló la constitucionalidad del contrato controvertido), se ha seguido aplicando el criterio convencional marcado por el CEDS en el ámbito de la jurisdicción ordinaria (por ejemplo, Sentencia $n^{\circ} 352$ de 5 de noviembre de 2014 del Juzgado de lo Social $\mathrm{n}^{\circ} 3$ de Barcelona, procedimiento de despido $\mathrm{n}^{\circ}$ 116/2014; ese criterio también ha sido seguido en apelación o suplicación por algunos Tribunales Superiores de Justicia ${ }^{9}$, sin que el Tribunal Supremo se haya pronunciado al respecto sobre el fondo ${ }^{10}$, al no admitir las decisiones del CEDS como jurisprudencia de contraste o doctrina contradictoria a la luz del artículo 219.2 de la Ley de la Jurisdicción Social $\left.^{11}\right)$.

Lo más relevante, finalmente, es que ese criterio de la jurisdicción ordinaria ejerciendo acertadamente el control de convencionalidad ha acabado contando con el

\footnotetext{
${ }^{9}$ Entre otros, por la Sala de lo Social del TSJ de Canarias (por ejemplo, sentencias de fecha 28 de enero, 30 de marzo y 18 de abril de 2016, en los recursos de suplicación, respectivamente, $\mathrm{n}^{\circ} 581 / 2015, \mathrm{n}^{\circ}$ 989/2015 y no 110/2016), o del TSJ de Castilla y León (Valladolid; por ejemplo, sentencia de 26 de septiembre de 2015, recurso de suplicación $n^{\circ} 1527 / 2016$ ).

${ }^{10}$ En efecto, el Auto de 4 de noviembre de 2015 de la Sala de lo Social del Tribunal Supremo resolvió declarar la inadmisión del recurso de casación para la unificación de doctrina interpuesto por un trabajador contra la sentencia dictada por la Sala de lo Social del TSJ de Cataluña de fecha 2 de diciembre de 2014 (recurso de suplicación $n^{\circ} 5253 / 14$, interpuesto por la empresa condenada en la instancia) frente a la sentencia del Juzgado de lo Social ${ }^{\circ} 1$ de Mataró de fecha 9 de abril de 2014 (procedimiento de despido ${ }^{\circ}$ 492/2013). Esta sentencia del Juzgado de lo Social había sido estimatoria y declaró que la extinción del contrato indefinido de apoyo a emprendedores del trabajador recurrente (éste había empezado a prestar sus servicios el 14 de mayo de 2012, notificándole la empresa el 26 de abril de 2013 la extinción de su contrato con efectos de 13 de mayo de 2013, por no haber superado el período de prueba) debía ser calificada como despido improcedente. Lo interesante de la sentencia del Juzgado de lo Social es que, en una plausible argumentación jurídica que revela una correcta aprehensión del sistema constitucional de fuentes y particularmente del ordenamiento laboral, descarta la aplicación de la disposición (art. 4.3) de la Ley 3/2012, de 6 de julio, de reforma del mercado de trabajo que estableció esa figura contractual, por disconformidad con el art. 4.4 CSE a la luz de la Decisión de fondo del CEDS de 23 de mayo de 2012 de resolución de la Reclamación n ${ }^{\circ}$ 65/2011 dictada contra Grecia. Con ello, el Juzgado de instancia ejerció con determinación y convicción el control de convencionalidad. Vid. GONZÁLEZ DE LA RIVERA I SERRA, X.: "Conversaciones entre la norma internacional y la norma interna: la aplicación por los órganos judiciales", en FARGAS FERNÁNDEZ, J. (Coord.): Los derechos laborales desde la perspectiva de la teoría general del contrato y de la normativa internacional, Barcelona, Huygens Editorial, pp. 85-120.

${ }^{11}$ Postura confirmada, entre otros, mediante el Auto TS no 1359 de 10 de enero de 2019 (recurso para unificación de doctrina $\left.\mathrm{n}^{\circ} 765 / 2018\right)$, FJ 2.
} 
respaldo contundente y su "bendición" mediante la STC 140/2018, de 20 de diciembre (FJ 6) ${ }^{12}$, reforzando con ello la efectividad de la tutela multinivel de los derechos sociolaborales.

\section{LA JURISPRUDENCIA RELATIVA AL SISTEMA DE INFORMES DURANTE 2019}

\section{Balance conjunto}

\subsection{Aspectos generales}

Como se anticipaba, las conclusiones del CEDS correspondientes a 2019 (adoptadas en enero de 2020 y publicadas el 24 de marzo de 2020) sobre los informes ordinarios (presentados cada año por los Estados Partes sobre uno de los cuatro bloques temáticos en los que se estructura la CSE a estos efectos) versaron sobre el grupo IV, relativo a los derechos de "Niños, familias, migrantes" (artículos 7, 8, 16, 17, 19, 27 y 31), y cubrieron el período de referencia de 1 de enero de 2014 a 31 de diciembre de 2017.

El CEDS adoptó 896 conclusiones con relación a 37 Estados (la mayor parte de ellos sometieron un informe sobre el conjunto de disposiciones de ese grupo temático, con la excepción de 7 Estados que, al haber aceptado el procedimiento de reclamaciones colectivas -en este caso, Croacia, Chipre, República Checa, Países Bajos, Noruega, Eslovenia y Suecia-, se limitaron a enviar un informe simplificado sobre el seguimiento de las decisiones adoptadas por el CEDS en el marco de dicho grupo temático ${ }^{13}$ ), declarando 289 violaciones de derechos de la CSE, 453 conclusiones de conformidad y 154 casos de "aplazamiento" ("deferral" en inglés, o "ajournement" en francés) por ausencia de información o de elementos de prueba necesarios en los informes nacionales. Esta última situación, como siempre insistimos, es reprochable a la luz de las obligaciones internacionales asumidas por los Estados Partes.

Por otro lado, durante el ciclo relativo a 2019 formularon comentarios u observaciones críticas a los informes nacionales de varias Estados Partes algunas organizaciones sindicales y patronales, así como organizaciones no gubernamentales. En concreto, en el caso de España se formularon comentarios contradictorios al informe

\footnotetext{
${ }^{12}$ Así de elocuente es la catalogación de la STC 140/2018 que efectúa con tino SALCEDO BELTRÁN, C.: "Control de convencionalidad de los tratados internacionales: bendición constitucional (STC 140/2018, de 20 de diciembre) y aceptación urbi et orbi de su enjuiciamiento por la jurisdicción ordinaria", marzo 2019 (https://baylos.blogspot.com/2019/03/legalidad-de-los-tratados.html).

${ }^{13}$ Ese informe simplificado sobre el seguimiento de las reclamaciones colectivas se remite cada dos años; en este caso, el citado grupo lo tuvo que enviar antes del 31 de octubre de 2018. Se trata del grupo B, compuesto por esos siete países. El otro grupo, el A, está compuesto por los otros ocho países (que integran los 15 que han aceptado el procedimiento de reclamaciones colectivas): Bélgica, Bulgaria, Finlandia, Francia, Grecia, Irlanda, Italia y Portugal. Los próximos informes sobre las disposiciones aceptadas, que debían presentarse antes del 31 de diciembre de 2019, se refieren a los siguientes artículos del grupo temático "Empleo, formación e igualdad de oportunidades": 1, 9, 10, 15, 18, 20, 24 y 25 . A los Estados que aceptaron el procedimiento de reclamaciones colectivas y pertenecientes a ese grupo A se les instó a presentar, también antes del 31 de diciembre de 2019, un informe simplificado sobre el seguimiento dado a las reclamaciones colectivas en esas materias.
} 
gubernamental por parte de los sindicatos CCOO y UGT en fecha 15 de abril de 2019. Esos comentarios u observaciones revisten un papel nada desdeñable, dado que proporcionan al CEDS elementos de contradicción procesal frente a los informes gubernamentales.

Además, el CEDS encabezó la compilación de sus conclusiones de 2019 (publicadas, como se decía, el 24 de marzo de 2020), como es habitual, con una Introducción general, en donde lo más destacado radica en la adopción de dos Observaciones Interpretativas tendentes a desarrollar y clarificar su jurisprudencia en ámbitos importantes y de candente actualidad.

En este caso, la primera Observación interpretativa versó sobre los artículos $8 \S 4$ y $8 \S 5$, que reconocen derechos específicos para proteger a las trabajadoras durante el embarazo y la maternidad, con el propósito de preservar la salud de la madre y del niño. Dicha protección presupone que las mujeres puedan reclamar condiciones de trabajo seguras y saludables, que tengan debidamente en cuenta las necesidades particulares durante este período. Para el CEDS, por su especificidad vinculada género, el embarazo y la maternidad solo afectan a las mujeres, por lo que cualquier tratamiento menos favorable que resulte de ello debe considerarse una discriminación directa basada en el sexo. En consecuencia, el retroceso o incumplimiento de los derechos especialmente destinados a proteger la salud y la seguridad de la madre y el niño durante el embarazo y la maternidad, constituyen asimismo una discriminación directa por motivos de sexo. De ello se deduce que, para garantizar que no medie discriminación por razón de sexo durante el período cubierto por la protección, las trabajadoras no han de estar en una situación menos favorable, incluso en materia de ingresos, debiendo operarse si fuera necesario un ajuste de sus condiciones de trabajo para asegurar que se beneficien del nivel de protección que requiere su salud. Por lo tanto, cuando una mujer no pueda ejercer su actividad profesional en su lugar de trabajo debido a problemas de salud y seguridad y deba ser reubicada en otro puesto (o incluso cuando no pueda operarse esa reubicación), los Estados deben asegurar que, durante el período cubierto por la protección, la persona interesada tenga derecho a la remuneración media que percibía anteriormente o reciba beneficios de seguridad social correspondientes al menos al 100\% de dicha remuneración. Además, debería tener derecho a volver a su puesto anterior.

Y la segunda Observación interpretativa abordó el artículo 17\$2 CSE con relación a la participación de actores privados en la educación. A tal efecto, el CEDS recuerda que dicha disposición obliga a los Estados a establecer y mantener un sistema educativo accesible y efectivo, estableciendo que dichas obligaciones se pueden cumplir directamente o mediante la participación de actores privados. Y, en esa línea, el CEDS presta atención a los Principios Rectores de Abiyán sobre las obligaciones de los Estados en materia de derechos humanos en la educación pública y la regulación de la participación privada en la educación. A este respecto, la obligación de los Estados de respetar la libertad de los padres de elegir una institución educativa que no sea pública no modifica la obligación establecida por el Derecho internacional de los derechos humanos de proporcionar educación pública inclusiva y de calidad. Asimismo, la oferta de 
alternativas educativas por parte de actores privados no debe ser perjudicial para la financiación o la oferta de educación pública en términos de calidad o accesibilidad.

Como complemento de esas Observaciones, el CEDS formula una serie de cuestiones generales que orientan la redacción de los informes gubernamentales, con efecto de perfilar las respuestas de los Gobiernos acotándoles su margen de discrecionalidad. Así, una primera pregunta sobre el artículo $7 \S 1$ tiende a detectar el trabajo ilegal de menores puesto que, si bien la mayor parte de las legislaciones de los Estados Partes es conforme con la CSE en materia de edad mínima de admisión al trabajo, la situación en la práctica es preocupante, existiendo en bastantes países un déficit de datos oficiales sobre la amplitud del problema; por tal motivo, el CEDS pide que los Estados proporcionen informaciones sobre medidas precisas (a través de la inspección de trabajo o de los servicios sociales) para detectar ese trabajo infantil, incluido el de niñas y niños que trabajan en la economía informal, identificando y supervisando los sectores fuertemente sospechosos de contar con menores trabajando ilegalmente. Una segunda cuestión general tiene que ver con el artículo 17§1, mostrando su preocupación el CEDS por una doble vertiente, a saber: el estatuto jurídico del menor (puesto que muchos menores son registrados como apátridas, con graves consecuencias para el acceso a los derechos y servicios esenciales tales como educación o salud, instándose en este sentido a los Estados para que registren los nacimientos, especialmente en el caso de grupos vulnerables como personas de etnia gitana, solicitantes de asilo o menores en situación irregular) y el derecho a la asistencia (requiriendo a los Estados para que proporcionen indicadores sobre las medidas adoptadas para combatir la infantilización de la pobreza en sectores como el acceso a la salud, la educación y la vivienda, sin discriminación que afecte a minorías étnicas, menores con discapacidad o tutelados por instituciones). Por último, una cuestión general sobre el alcance del artículo $17 \S 2$ pide a los Estados datos sobre las medidas de lucha (sensibilización, prevención e intervención) contra el acoso en las escuelas, así como sobre la voz de los menores en el ámbito educativo, es decir, sobre su participación en el amplio abanico de toma de decisiones y de actividades ligadas a la educación, incluso en contextos de aprendizaje específico.

Por añadidura, pese al difícil contexto de prolongación durante ya más de una década de la crisis económica y financiera (que difícilmente podía hacer presagiar su acentuación, incluso en clave social y política, y seguramente cultural, por la reciente pandemia provocada por el COVID-19), el CEDS ha tomado nota de algunos desarrollos positivos en la ejecución de sus conclusiones por los Estados condenados en cada caso. Esos avances se han verificado, por ejemplo, en el caso del artículo $7 \S 1$, por una reciente modificación en 2018 en Macedonia del Norte sobre la ley relativa a las relaciones laborales (publicada en el Diario Oficial $n^{\circ}$ 120/2018) en relación con los trabajos ligeros y las vacaciones para los niños; su nuevo artículo 18.2 ha establecido: "La presente ley prohíbe el trabajo de los menores de 15 años o todavía sujetos a escolaridad obligatoria, a excepción de la participación en actividades autorizadas por la ley, dentro del límite de dos horas por día y doce horas por semana y durante las 
vacaciones escolares de seis horas al día o treinta horas a la semana, período durante el cual los niños tienen derecho a dos semanas de vacaciones".

En el supuesto del artículo 8\$1, en el Distrito de Brčko (en Bosnia-Herzegovina) fue modificado el 23 de agosto de 2014 el artículo 45 de su Código de trabajo, con objeto de propiciar que, durante su permiso de maternidad, una asalariada tenga derecho a prestaciones por un montante equivalente al salario medio neto percibido en el curso de los seis meses que precedan al permiso. En Armenia, la Ley n ${ }^{\circ} \mathrm{HO}-160-\mathrm{N}$ de 27 de octubre de 2010 fue modificada por la Ley n ${ }^{\circ}$ HO-206N de 1 de diciembre de 2014 con el fin de reemplazar la "subsidio de incapacidad temporal" para las personas embarazadas o con permiso de maternidad a través de nuevas "prestaciones de maternidad". En Luxemburgo, de conformidad con la Ley del 15 de diciembre de 2017, la duración del permiso postnatal se ha incrementado de ocho a doce semanas. En Macedonia del Norte, una modificación de 2015 de la ley relativa a las relaciones laborales (Diario oficial $\mathrm{n}^{\mathbf{o}}$ 72/15) ha elevado la duración del permiso de maternidad remunerado en caso de nacimientos múltiples de doce a quince meses. Y en República Eslovaca, el nivel de prestaciones de maternidad ha aumentado del 65\% (Conclusiones 2015) al 75\% del salario de la persona interesada (la situación ahora se ajusta al artículo $8 \S 1$ CSE sobre este punto).

Por su parte, en el caso del artículo 8\$2, cabe mencionar en Francia el artículo 10 de la Ley $n^{\circ}$ 2016-1088 de 8 de agosto de 2016 relativa al trabajo, la modernización del diálogo social y la seguridad de las carreras profesionales, a tenor del cual el período legal de prohibición de ruptura del contrato laboral por iniciativa del empleador para mujeres al final de sus permisos relacionados con el embarazo y la maternidad se ha extendido de cuatro a diez semanas después del permiso de maternidad y ahora incluye el período de permisos remunerados disfrutado inmediatamente después del permiso de maternidad (esta protección beneficia no únicamente a las mujeres embarazadas, sino también al cónyuge asalariado de la mujer embarazada, así como a los padres adoptivos). Además, es interesante citar el nuevo Código del Trabajo de Lituania (vigente desde el 1 de julio de 2017), que establece protección frente al despido a las mujeres embarazas desde el día en que notifican a su empleador el embarazo y hasta el cuarto mes del niño.

En lo que atañe al artículo 16, en Austria, tras algunos cambios legislativos, la situación de siete de los nueve estados federados se ha ajustado a la CSE, en la medida en que sus normas sobre ayudas a la vivienda ahora aseguran igualdad de trato a los extranjeros (solamente en dos Länder, Baja Austria y Viena, subsiste una diferencia de trato basada en la exigencia de cinco años de residencia). En Islandia, la Ley n n $^{\text {75/2016 }}$ relativa a la ayuda a la vivienda ha favorecido el aumento del número de viviendas sociales y ha establecido una obligación de las entidades locales para conceder ayudas complementarias en situaciones de gran precariedad social y financiera. Desde otra óptica de la protección de la familia, en Estonia ha aumentado considerablemente el montante de las prestaciones por hijo a cargo (pasando de $19 €$ mensuales en 2013 a $55 €$ en 2017), 
mientras en Hungría la modificación en 2014 de la Ley sobre el apoyo a la familia ha extendido las prestaciones familiares a los nacionales de países terceros que sean titulares de un permiso único si han obtenido autorización para trabajar durante más de seis meses.

Por lo que se refiere a los avances en el ámbito del artículo 17, Escocia, Estonia, Francia, Gales, Irlanda, Lituania, Malta y Montenegro han abolido todas las formas de castigo corporal en todos los contextos. Además, en Irlanda, se ha puesto fin a la práctica de detener a menores en centros penitenciarios para adultos. Y, por otra parte, en Moldavia y en Ucrania, se han constatado esfuerzos para garantizar que un menor no pueda ser puesto bajo tutela institucional debido a la situación financiera de la familia.

En cuanto al artículo 27, en Francia, en virtud de la Ley No 2014-459 de 9 de mayo de 2014, las empresas pueden establecer un sistema para conceder días de descanso a los padres de un menor gravemente enfermo, mientras que la Ley $\mathrm{N}^{\circ}$ 2018-84 del 13 de febrero de 2018 creó un dispositivo similar que permite la concesión de días de descanso no disfrutados en beneficio de los cuidadores familiares de personas con pérdida de autonomía o con una discapacidad. Por su lado, en Turquía, en virtud de la Ley $\mathrm{N}^{\circ} 6663$, que entró en vigor el 10 de febrero de 2016, los trabajadores con responsabilidades familiares (tanto del sector público como del privado) tienen la posibilidad de trabajar a tiempo parcial hasta que el menor alcance la edad de educación obligatoria, de suerte que las solicitudes de trabajo a tiempo parcial no pueden constituir un motivo válido para el despido.

En lo atinente al artículo 31, Francia se ha adecuado a la Carta con respecto a la protección jurídica del derecho a la vivienda para los no nacionales: en concreto, en 2011, el CEDS había concluido que la condición de residencia previa de al menos dos años para poder presentar una solicitud al comité responsable del procedimiento DALO (“droit au logement opposable"/derecho de vivienda exigible) era excesiva; una condición que la máxima instancia de la jurisdicción contencioso-administrativa (el Consejo de Estado) anuló, lo que provocó la modificación de la ley de acuerdo con los parámetros de la CSE poniendo fin a ese requisito de residencia de dos años y, así el CEDS concluyó en 2019 la conformidad con el artículo $31 \S 1$ sobre este punto. Con respecto a Portugal, aunque fuera del período de referencia, el CEDS tomó nota, pese a no mencionarse en el informe nacional, de la nueva ley básica de vivienda (Ley No 83/2019; no mencionada en el informe nacional).

En el caso de Andorra, aunque no existe una prohibición formal de desalojar a las personas que disfrutan de un alojamiento temporal (hoteles), cuando un hotelero ya no quiere seguir hospedando a una persona, lo notifica a los servicios sociales para que puedan encontrar una solución de realojamiento, de manera que, tras reservar su posición sobre este punto en 2017, el CEDS ha concluido en 2019 la conformidad con el artículo 31§2. Del mismo modo, el CEDS ha considerado que Finlandia sigue comprometida en la lucha contra el fenómeno del "sinhogarismo" conforme al artículo 31§2, dando continuidad a la implementación del modelo "housing first" ("la vivienda lo primero"), 
concretándose en el informe nacional que a finales de 2017 había 7.112 personas sin hogar (menos del $0.2 \%$ de la población), existiendo un nuevo plan de acción de prevención de la falta de vivienda para el período 2016-2019, fijándose el objetivo actual en reducir el número de personas sin hogar a menos de 4.000 personas para 2023.

Finalmente, en cuanto al cumplimiento del artículo 31§3, aunque en el supuesto de Lituania ha reiterado la no conformidad (que es reiteración de la apreciada ya en las concusiones de 2011, 2015 y 2017) con respecto a la protección jurídica frente a la prohibición de expulsión durante el invierno, se ha considerado conforme a la Carta el establecimiento de la obligación de realojamiento cuando el desalojo deriva de imperativos de interés general (por ejemplo, en caso de demolición y reconstrucción de un inmueble) o la indemnización en caso de desalojo ilegal. Por último, en el caso de Italia el CEDS ha verificado un desarrollo positivo de la jurisprudencia nacional, particularmente de la sentencia de la Corte Constitucional de 20 de julio de 2018 en materia de acceso de los nacionales de países terceros a la ayuda al alquiler de viviendas, tras dictaminar que era manifiestamente irrazonable y arbitrario condicionar el acceso a dichas ayudas al requisito de residencia de diez años en el territorio nacional o cinco años en el territorio regional.

\subsection{Aspectos específicos}

Entrando en el examen de las conclusiones adoptadas con relación a los informes ordinarios, el CEDS se ocupó en 2019, como se dijo, del grupo IV, analizando el respeto de los artículos 7 (derecho de la infancia y la adolescencia a protección, especialmente en el terreno laboral), 8 (derecho de las trabajadores a la protección de la maternidad), 16 (derecho de la familia a la protección social, jurídica y económica), 17 (derecho de la infancia y la adolescencia a la protección social, jurídica y económica), 19 (derecho de los trabajadores migrantes y sus familias a protección y asistencia), 27 (derecho de los trabajadores con responsabilidades familiares a la igualdad de oportunidades y de trato) y 31 (derecho a la vivienda). Como quiera que el CEDS realiza un análisis tanto de la práctica como de la normativa de cada Estado parte, buena parte de las conclusiones del CEDS tiene que ver con violaciones en la praxis de los derechos reconocidos en la CSE, mientras otras conclusiones revelan una legislación nacional contraria al tratado europeo de derechos sociales.

En primer término, en relación con al artículo 7 CSE, el CEDS recuerda que dicha disposición garantiza el derecho de los niños y jóvenes a la protección. Prohíbe el trabajo infantil (menores de 15 años) y la asignación de menores a tareas peligrosas o insalubres. También les brinda protección especial contra los peligros físicos y morales, como la explotación sexual. Con tal premisa, el CEDS determinó que la situación de un gran número de Estados no era conforme al artículo $7 \S 1$, debido al incumplimiento en la práctica de la prohibición del empleo de menores de 15 años (Albania, Armenia, Azerbaiyán, Bosnia-Herzegovina, Georgia, Moldavia, Rumania, Serbia, Turquía y Ucrania). Otro aspecto importante radica en que el trabajo considerado como "ligero" que 
pueden realizar menores de 15 años o aún sujetos a educación obligatoria no está supervisado adecuadamente en muchos Estados, puesto que permiten esos trabajos ligeros durante un período excesivo (Armenia, Estonia, Georgia, Grecia, Lituania, Malta, Portugal).

Por otra parte, el artículo $7 \S 5$ también garantiza el derecho de los jóvenes trabajadores y aprendices a una remuneración justa, una equidad del salario que se evalúa en comparación con el salario de un adulto al comienzo de su carrera o el salario mínimo legal reconocido a los adultos, no pudiendo superar la diferencia el 20\%; pues bien, ese criterio de equidad no se satisface en un gran número de Estados (Albania, Alemania, Andorra, Armenia, Azerbaiyán, Bélgica, España, Georgia, Rumania, Reino Unido, Serbia y Ucrania). Por su lado, en lo relativo al artículo $7 \S 10$ (protección contra peligros físicos y morales, que cubre asimismo la protección de los menores contra la explotación sexual, la explotación laboral y otras formas de explotación, así como la protección contra el mal uso de las tecnologías de la información y contra la trata), el CEDS observó que la legislación de algunos Estados no protege a todos los menores frente a todas las formas de explotación sexual (Bosnia-Herzegovina, Georgia, Rusia, Turquía y Ucrania) o contra la explotación económica (Albania, Georgia).

El segundo bloque jurisprudencial interesante tiene que ver con el artículo 8 CSE. En concreto, en relación con el artículo 8§1, el CEDS evaluó en particular si las asalariadas podían, en la legislación y en la práctica, disfrutar de un permiso postnatal remunerado de al menos seis semanas, centrándose en un aspecto esencial como es el de verificar si todas los empleadas afectadas, tanto en el sector privado como en el público, continuaron recibiendo al menos el $70 \%$ de su remuneración durante el período de maternidad obligatoria (se consideró contraria sobre este punto la situación en BosniaHerzegovina, Irlanda, Moldavia, Reino Unido, Rusia y Turquía). Desde otra perspectiva, el CEDS observó que en casi un tercio (27\%) de las situaciones examinadas, era posible despedir a las empleadas embarazadas o con permiso de maternidad en circunstancias que iban más allá de las permitidas por el artículo 8 \$2 (Bosnia-Herzegovina, España, Irlanda, República Eslovaca y Turquía), o que la empleada en cuestión no pudiera obtener compensación alguna o adecuada en caso de despido abusivo (Albania, BosniaHerzegovina y Turquía), especialmente cuando su readmisión resultaba imposible (Albania, Finlandia, Italia Turquía).

Por lo demás, con respecto al derecho a pausas remuneradas por lactancia (artículo 8§3) y a la protección e materia de trabajo nocturno (artículo 8§4) o de naturaleza peligrosa, insalubre o nocivo (artículo $8 \S 5$ ) de las empleadas embarazadas, que recientemente hayan dado a luz o recurran a la lactancia de sus hijos, las pocas conclusiones de incumplimiento se deben esencialmente al hecho de que no se ha establecido suficientemente en la praxis que las personas afectadas se beneficien, a la luz de la legislación pertinente, de una protección específica adecuada (Francia y España en el caso del artículo 8§3; Bosnia-Herzegovina, Georgia, Moldavia y Polonia en el supuesto del artículo 8§4, y Azerbaiyán, Bosnia-Herzegovina, Georgia, Hungría, Moldavia, Serbia, 
Turquía y Ucrania en lo atinente al artículo 8\$5).

Un tercer bloque jurisprudencial tiene que ver con el artículo 16 CSE (protección social, jurídica y económica de la familia), procediendo el CEDS al examen de cuestiones tales como la vivienda para las familias, instalaciones de cuidado de niños, servicios de asesoramiento familiar, la participación de asociaciones que representan a familias, los derechos y responsabilidades de los cónyuges, servicios de mediación, violencia doméstica contra la mujer y prestaciones familiares. Pues bien, la conculcación más frecuente, en términos cuantitativos, tiene que ver con las prestaciones familiares: concretamente, de un total de 33 Estados examinados, la situación de 15 (Azerbaiyán, Bélgica, Bosnia-Herzegovina, España, Grecia, Irlanda, Italia, Letonia, Macedonia del Norte, Países Bajos -Curaçao-, Moldavia, Montenegro, Polonia, Turquía y Ucrania) era contraria a la CSE sobre este punto. Para 9 Estados, la no conformidad derivaba del hecho de exigir, para el acceso a dichas prestaciones familiares, un período de residencia de más de seis meses (hasta seis, es aceptable para el CEDS, al tener carácter no contributivo) para nacionales de otros Estados Partes (Azerbaiyán, Bélgica, Bosnia-Herzegovina, Grecia, Italia, Letonia, Macedonia del Norte, Moldavia, Polonia).

En este mismo terreno, el CEDS evalúa la suficiencia de las prestaciones familiares a la luz de dos criterios: de un lado, verifica la suficiencia de la cobertura (es decir, la proporción de familias cubiertas), puesto que incluso aunque la CSE no establezca la obligación de tener un sistema universal (las prestaciones por hijos a cargo pueden estar condicionadas a un umbral de ingresos), estos beneficios se deben proporcionar a un número significativo de familias (por ejemplo, si las prestaciones solo se reservan para las familias por debajo del umbral de pobreza, el CEDS considera que la cobertura es insuficiente). De otro lado, el segundo criterio consiste en la cuantía de las prestaciones, cuya suficiencia se considera por el CEDS tomando como referencia el 5\% del ingreso medio ajustado, por debajo del cual la situación no es conforme (a menos que se complemente con otros beneficios que cubran a un número significativo de familias). El caso es que la suficiencia de las prestaciones, a la luz de dichos criterios, fue considerada contraria al artículo 16 en nueve supuestos (Azerbaiyán, España, Italia, Letonia, Macedonia del Norte, Moldavia, Montenegro, Polonia y Ucrania).

Otras vulneraciones de esta disposición de la Carta tienen que ver con la vivienda de las familias. De los 33 Estados examinados, la situación de 18 (Azerbaiyán, Austria, Bélgica, Bosnia-Herzegovina, Bulgaria, Estonia, Francia, Grecia, Hungría, Irlanda, Italia, Macedonia Norte, Malta, Moldavia, Portugal, Rumania, Rusia y República Eslovaca] ha sido declarada insatisfactoria. Los motivos de incumplimiento han sido variados: a título de ejemplo, desigualdad de trato en perjuicio de personas extranjeras (por duración de la condición de residencia: Austria y Malta), oferta insuficiente de vivienda digna para familias vulnerables (Irlanda y Rusia), desprotección jurídica de las personas afectadas por la amenaza de desalojo (Bosnia-Herzegovina, Estonia, Hungría y Rumania) o precariedad sufrida por familias vulnerables de etnia gitana o modo de vida itinerante (Bélgica, Bulgaria, Francia, Grecia, Hungría, Irlanda, Italia, Moldavia, Portugal, Rumania, Rusia y República Eslovaca). 
Y se completa el cuadro de vulneraciones del artículo 16 CSE con la lacra que comporta la insuficiente adopción de medidas para combatir la violencia doméstica, con conclusiones negativas en un buen número de países (Azerbaiyán, Bosnia-Herzegovina, Bulgaria, Moldavia, Montenegro, Rumania, Rusia, República Eslovaca, Turquía y Ucrania).

Otro bloque jurisprudencial relevante se refiere al artículo 17 CSE (protección social, jurídica y económica de la infancia y la juventud). Se trata de una disposición con amplio alcance, que cubre aspectos como el estatuto jurídico del menor; su protección contra la violencia, los malos tratos y los abusos; los derechos de los menores en instituciones tutelares; la situación de los menores que han infringido la ley o el derecho a la asistencia.

Como balance general, en 2019 el CEDS examino 33 situaciones nacionales en relación con el apartado 1, concluyendo la contrariedad a dicho precepto en 19 países. En esta línea, el CEDS ha reprochado que la prohibición de todas las formas de castigo corporal, que es el núcleo de esta disposición de la Carta, aún no es explícita en varios Estados, especialmente del infligido en el hogar familiar (Armenia, Bélgica, BosniaHerzegovina, Georgia, Reino Unido -para el caso de Inglaterra, pues en Escocia y Gales sí se han eliminado, aunque sea fuera del período de referencia-, Rusia, Serbia y República Eslovaca). Por otro lado, en la mayoría de Estados el CEDS ha constatado que los procedimientos para ubicar a los menores en instituciones tutelares son respetuosos con el artículo 17 CSE, habiéndose procedido a la desinstitucionalización en varios Estados (con cierre de grandes instituciones y promoviendo la acogida en hogares de guarda o en estructuras de tipo familiar, con problemas sin embargo todavía en algunos países como Armenia y Ucrania). En lo que concierne a la responsabilidad penal de los menores, la edad sigue siendo manifiestamente demasiado baja en Irlanda, Reino Unido (si bien Escocia la ha elevado a 12 años) o Turquía. En algunos países, todavía es posible la detención de jóvenes durante período prolongado en espera de juicio, en disconformidad con el artículo 17 CSE (Armenia, Austria, Bélgica, Dinamarca, Francia, Hungría, Letonia, Polonia, Rusia, República Eslovaca, Turquía), habiéndose formulado por el CEDS una pregunta concreta sobre el aislamiento en celda de menores (lo que plantea problemas en Dinamarca, lo mismo que el uso de técnicas de restricción dolorosas utilizadas en Reino Unido en instalaciones para delincuentes jóvenes). En lo que atañe al derecho a la asistencia de menores, el CEDS ha vuelta a expresar su preocupación por la situación de menores migrantes en situación irregular (acompañados o no) y solicitantes de asilo, debido a las condiciones de alojamiento inadecuadas y a menudo inseguras frente a la violencia y el abuso (Grecia, Hungría). Por añadidura, para mejorar la protección y perfilar su jurisprudencia, el CEDS ha planteado cuestiones sobre el alcance de la utilización de las pruebas óseas para determinar la edad de los menores no acompañados y sobre las medidas para paliar la pobreza infantil bajo el ángulo del artículo $17 \S 1$. Desde este mismo prisma, el CEDS exige de los Estados Partes que determinen las medidas para reducir la apatridia (asegurar que cada menor apátrida sea identificado, simplificar los procedimientos para obtener la nacionalidad, tomar medidas para identificar a los niños 
que no registrados al nacer y facilitar el registro de nacimientos).

Por lo que se refiere al artículo $17 \S 2$ CSE revisada (que no tiene equivalente en la CSE de 1961 y, por ende, interpela fuertemente a países como España, con la asignatura pendiente de acepción de esa versión revisada), crea cualificadas obligaciones positivas para los Estados Partes, sobre todo para garantizar la igualdad de acceso a la educación, prestando especial atención a los grupos vulnerables. El CEDS analizó la situación en 26 países, hallando violaciones en una decena de ellos. Aunque en la mayoría de Estados exista un sistema educativo accesible y efectivo (con exclusiones sufridas por menores en situación irregular en países como Montenegro o Rusia), en algunos sigue habiendo tasas bajas de escolarización en la enseñanza obligatoria (Armenia, Bulgaria, Macedonia del Norte, Moldavia -en este caso, afectando de manera especial a menores romaníes-, Rumania, República Eslovaca) continúan teniendo bajas tasas de matrícula en la educación obligatoria; en este mismo sentido, esos menores de etnia gitana siguen sufriendo segregación escolar (Hungría) o están sobrerrepresentados en clases especiales (Moldavia o República Eslovaca). En todo caso, el CEDS ha suscitado nuevas cuestiones para que los Estados respondan sobre las medidas efectivas adoptadas para combatir el acoso escolar y para fomentar la participación de niñas y niños en la educación.

El artículo 19 CSE (derechos de personas trabajadoras migrantes y sus familiares) ocupa otro sector jurisprudencial de una indudable actualidad, que ha sido particularmente problemático. La situación del conjunto de Partes Contratantes (con la excepción de tres de ellos, a saber, Estonia, Lituania y Reino Unido) no se ha ajustado a una o más de las disposiciones del citado artículo, siendo especialmente elevado el porcentaje de incumplimiento $(72 \%)$ del derecho a la reunificación familiar (artículo 19§6); lo cual constituye un verdadero desafío para el Consejo de Europa, puesto que el procedimiento de reunificación familiar es responsable de una gran parte de los flujos migratorios a Europa (del 30 al 50\% de la inmigración legal hacia la UE en los últimos diez años), planteando especiales obstáculos en esa "gestión" de la inmigración una condición de residencia excesiva o de dominio del idioma o requisitos de ingresos, abocando dichos motivos en muchos supuestos a la expulsión del trabajador migrante. Por otra parte, los incumplimientos del artículo $19 \S 1$ en algunos países (Bélgica, Francia, Georgia, Italia y Turquía) ha revelado problemáticas medidas jurídicas y prácticas para combatir el racismo, la xenofobia y el discurso del odio (incluidos los medios de comunicación). En contrapartida, el CEDS consideró que en la mayoría de países había adecuación al artículo $19 \$ 5$ (igualdad de trato en la ley y en la práctica con respecto al pago de impuestos, tasas o contribuciones relacionadas con el trabajo), o que se habían implementado mejoras para facilitar las condiciones de acogida de los trabajadores migrantes y sus familias (artículo 19§2). Sin embargo, ha seguido resultando problemático el requisito de duración de residencia para poder acceder a una vivienda social (artículo 19§4) que, aunque se aplique a nacionales y no nacionales, comporta según el CEDS una discriminación indirecta para los segundos. En el mismo orden de ideas, aunque la situación haya mejorado en comparación con ciclos anteriores, el respeto del artículo $19 \S 8$ ha sido puesto en entredicho en diversos países (Grecia, Luxemburgo, 
Macedonia del Norte, Polonia, Rumania y Turquía), al interpretarse de manera excesivamente laxa los motivos de expulsión, incluso cuando los trabajadores migrantes no amenazaban la seguridad nacional ni violaban el orden público o la moral.

Un ámbito jurisprudencial, igualmente de gran alcance social, guarda conexión con la conciliación de la vida laboral y familiar (artículo 27 CSE revisada). La jurisprudencia del CEDS garantiza el derecho de trabajadoras y trabajadores con responsabilidades familiares a la igualdad de oportunidades y de trato. La legislación nacional debe reconocer a mujeres y hombres un derecho individual al permiso parental, que debería otorgarse a cada progenitor y al menos parte de él debería ser intransferible. En sus conclusiones, el CEDS ha constatado que efectivamente la mayoría de Estados que han aceptado esta disposición de la Carta reconocen a ambos progenitores ese derecho. Más concretamente, concluyó que la situación era disconforme con el artículo $27 \S 1$ en un solo caso (Georgia), debido a que la legislación no prevé específicamente fórmulas para facilitar esa conciliación entre vida profesional y privada para personas con responsabilidades familiares. Desde la perspectiva del artículo $27 \S 2$, el problema no ha residido tanto en que la normativa interna confiera a hombres y mujeres un derecho individual al permiso parental, sino en garantizarles una compensación adecuada por la pérdida de ingresos durante ese período de licencia parental (problema que se verifica en Armenia, Azerbaiyán y Ucrania), o sencillamente porque el permiso parental no da lugar al pago de ningún subsidio o remuneración (Irlanda, Malta y Turquía). En fin, en lo que afecta al artículo $27 \S 3$, que prevé la prohibición de cualquier despido por razones de responsabilidad familiar y la existencia de recursos efectivos en caso de despido injusto, la contrariedad se ha verificado en tres países (Bulgaria, Italia y Turquía).

El último bloque jurisprudencial fundamental se ha centrado en el artículo 31 CSE revisada, que garantiza el derecho a la vivienda; si bien para el CEDS es susceptible de interpretarse como una obligación de "resultado", pero requiere que los Estados Parte implementen medios normativos, financieros y operativos capaces de lograr un progreso real, en un tiempo razonable y a costa de un progreso medible, hacia la realización de este derecho. Lo cierto es que el grado de cumplimiento sigue siendo relativamente bajo. En el caso del primer apartado sobre una vivienda adecuada (artículo 31§1), con la excepción de dos situaciones de conformidad (Andorra y Finlandia), la conculcación (en ocho países) se refiere especialmente a la pasividad de las autoridades públicas a la hora de mejorar los bajos estándares de las condiciones de alojamiento de las personas de etnia gitana (Francia, Grecia, Italia, Letonia, Portugal, Turquía y Ucrania) o la deficiente supervisión de esas inadecuadas condiciones habitacionales (Lituania y Turquía). Por su lado, el artículo $31 \S 2$ (reducción del sinhogarismo) se ha saldado en una conclusión de conformidad (Finlandia), mientras que su vulneración (en ocho países) deriva básicamente de la insuficiente protección jurídica de personas amenazadas por órdenes de desalojo, como la prohibición de llevar a cabo expulsión en invierno (Andorra, Francia, Grecia, Lituania, Portugal, Turquía y Ucrania), desalojos selectivos de personas de etnia gitana (Francia, Grecia e Italia), ausencia de medidas para prevenir y reducir la falta de 
vivienda (Francia, Italia y Turquía) o la protección insuficiente del derecho (Lituania, Portugal, Turquía y Ucrania). Finalmente, con la excepción otra vez del cumplimiento por parte de Finlandia del artículo $31 \S 3$ (costo de la vivienda accesible), sus vulneraciones se refieren principalmente a la escasez de viviendas sociales (Francia y Portugal), al incumplimiento de la igualdad de trato respecto de las personas extranjeras que se encuentran en situación legal con respecto a la vivienda social y a las ayudas de vivienda (condición de la duración de la residencia en Italia, relacionada con la infracción asimismo del artículo 19§4), o al específico acceso de personas de etnia gitana e itinerantes a la vivienda social o a esas ayudas para la vivienda (Francia e Italia).

\section{La situación española ${ }^{14}$}

Del grupo temático IV sometido a examen en 2019, los derechos reconocidos en los artículos 27 CSE revisada (conciliación de la vida familiar y profesional) y 31 CSE revisada (derecho a la vivienda) no han sido objeto de examen directo con relación a España (la problemática de la vivienda es analizada en parte bajo el ángulo de la protección de la familia a la luz del artículo $16 \mathrm{CSE}$ ), al no haber aceptado nuestro país el tratado revisado. ¿Cuál es el balance, entonces, de la jurisprudencia del CEDS con respecto a España en 2019 en lo que afecta a ese grupo IV sobre derechos de la infancia, de las familias y de las personas migrantes?

Pues bien, se han examinado veintiséis situaciones (el período de referencia sometido a examen discurrió desde el 1 de enero de 2014 hasta el 31 de diciembre de 2017) relacionadas con los artículos 7, 8, 16, 17 y 19 CSE [España no se encuentra vinculada únicamente, tras su denuncia el 4 de diciembre de 1990, por el párrafo b) del artículo 8.4 CSE, sobre prohibición del empleo de mujeres en ciertas actividades peligrosas]. El CEDS ha apreciado doce casos de conformidad (artículos 7\$1, 7§2, $7 \S 4$, $7 \S 6,7 \S 7,7 \S 8,8 \S 1,8 \S 4 \mathrm{a}>, 19 \S 1,19 \S 5,19 \S 7$ y $19 \S 8)$ y siete supuestos de violación (artículos 7§5, 8§2, 8§3, 16, 19§4, 19\$6 y 19\$10), además de diferir o aplazar el examen de siete situaciones (artículos $7 \S 3,7 \S 9,7 \S 10,17,19 \S 2,19 \S 3$ y 19\$9) ante la falta de información suficiente suministrada por las autoridades españolas. Avanzada esta breve síntesis, resulta del mayor interés, lógicamente, referirse a los siete casos de violación.

\section{Así pues, la primera conclusión de no conformidad se refiere al artículo 7 \$5}

CSE, que se considera vulnerado por dos motivos, reincidiendo en la misma violación que ya había quedado constatada en las conclusiones anteriores (2015), a saber: la remuneración de los jóvenes trabajadores no es equitativa, y no ha quedado acreditado que las sumas pagadas a los aprendices sean adecuadas. Con respecto al primer motivo,

\footnotetext{
${ }^{14}$ Una excelente síntesis de estas conclusiones 2019 referentes a España, en el trabajo de SALCEDO BELTRÁN, C.: "Crónica Europea. La crítica situación de los derechos sociales de la infancia, de las familias y de los migrantes: Conclusiones 2019 del Comité Europeo de Derechos Sociales", Derecho de las Relaciones Laborales, $\mathrm{n}^{\circ}$ 6, 2020, pp. 900-917, especialmente el interesante y crítica apartado titulado "Examen particular de España: una encrucijada de desacatos y reincidencias (nihil novum sub sole)" (pp. 910 y ss.).
} 
el CEDS constata que, pese a admitir la CSE que el salario de los jóvenes pueda ser inferior al salario de base de los adultos siempre que el desfase no sea desproporcionado (se acepta una diferencia del 30\% para los jóvenes de 15 años, o del $20 \%$ para quienes tengan entre 16 y 17 años), en el caso de España la diferencia sigue siendo desproporcionada y, por ende, no equitativa. A este respecto, el CEDS recordó que en 2016, según la base de datos EUROSTAT que el propio CEDS toma como referencia para su interpretación vinculante, el salario medio anual de un solo trabajador ascendió a $26,710.29 €$ brutos (o 2,225.86€ por mes durante 12 meses) o 20,998.93€ netos (es decir, $€ 1,749.91$ por mes durante 12 meses) tras descuentos de las cotizaciones a la seguridad social y retenciones de impuestos; por tanto, el SMI en relación con el salario medio se correspondía con un $34,10 \%$, lo que condujo al CEDS a concluir que la situación en España era contraria al artículo $4 \S 1$ de la Carta de 1961, por ser el salario mínimo de los trabajadores del sector privado insuficiente para garantizar un nivel de vida digno (Conclusiones 2018, artículo 41). Según el informe gubernamental, no hay diferencia de edad entre el salario mínimo para los trabajadores jóvenes menores de 18 años y el salario mínimo para los adultos. Ahora bien, al mismo tiempo el informe señala que el SMI para 2018 era de $24.53 €$ por día o $735.9 €$ por mes. Así pues, dado que el ingreso anual medio en 2018 según la OCDE fue de $26.880 €$ brutos (o 2.240€ mensuales), el CEDS considera nuevamente que no se garantiza el derecho de los jóvenes a una remuneración justa, reiterando así su requerimiento anterior, para que el próximo informe indique los salarios mínimos y medios, en valor neto, es decir, tras la deducción de impuestos y cotizaciones a la seguridad social.

En realidad, el otro motivo de violación deriva de la ausencia repetida de información, dado que las autoridades españolas han seguido sin suministrar datos sobre las sumas medias y mínimas netas que reciben los aprendices al inicio y al fin de su aprendizaje, lo que impide al CEDS comprobar que el sistema de aprendizaje no se aparta de su objetivo para utilizarse como medio abusivo de contratación de mano de obra barata. De hecho, el CEDS resalta que el informe gubernamental se ha limitado a reproducir formalmente las modificaciones introducidas mediante el Real Decreto-Legislativo $2 / 2015$, de 23 de octubre, por el que se aprueba el texto refundido de la Ley del Estatuto de los Trabajadores, concretamente diversos aparados del artículo 11.2 (contratos formativos): "El contrato para la formación y el aprendizaje se regirá por las siguientes reglas: (...) f) El tiempo de trabajo efectivo, que habrá de ser compatible con el tiempo dedicado a las actividades formativas, no podrá ser superior al setenta y cinco por ciento, durante el primer año, o al ochenta y cinco por ciento, durante el segundo y tercer año, de la jornada máxima prevista en el convenio colectivo o, en su defecto, a la jornada máxima legal. (...) g) La retribución del trabajador contratado para la formación y el aprendizaje se fijará en proporción al tiempo de trabajo efectivo, de acuerdo con lo establecido en convenio colectivo. En ningún caso, la retribución podrá ser inferior al salario mínimo interprofesional en proporción al tiempo de trabajo efectivo" ${ }^{15}$.

\footnotetext{
${ }^{15}$ Esta redacción no se vio afectada por la modificación posterior introducida mediante el Real Decretoley $6 / 2019$, de 1 de marzo.
} 
La segunda conclusión negativa radica en la contrariedad al artículo $8 \$ 2$, una disconformidad que viene de un anterior aplazamiento por falta de información en las conclusiones de 2015. En particular el CEDS concluye ahora la no conformidad "por cuanto las razones del despido de una empleada durante su embarazo o su permiso de maternidad van más allá más allá de las excepciones admitidas”. En verdad, no se trata tanto de una problemática acerca de las formales prohibiciones de despido contenidas en las disposiciones normativas previstas en el Estatuto de los Trabajadores aprobado mediante Real Decreto Legislativo 2/2015, de 23 de octubre (prohibición de despido de una empleada que se extiende desde el inicio del embarazo, durante todo el permiso de maternidad y hasta el final de los otros tipos de suspensión del contrato relacionados con la maternidad y la lactancia) y a tenor de sus artículos 52 a 55, en conexión con los artículos 108.2 y 122.2 de la Ley 36/2011, de 10 de octubre, reguladora de la jurisdicción social. Realmente, dada la información proporcionada en el informe gubernamental, el CEDS observa que todavía es posible despedir a una empleada durante su permiso de maternidad por diversos motivos, tales como los despidos colectivos, incluso aunque la empresa no haya cesado sus actividades (artículo 51 del Estatuto de los Trabajadores). El informe alude igualmente a la sentencia del Tribunal de Justicia de la Unión Europea de 22 de febrero de 2018 (Porras Gisado, asunto C-103/16) ${ }^{16}$, el cual haría considerado que los motivos económicos, técnicos, o relativos a la organización y producción que permiten a un empleador llevar a cabo legítimamente un despido colectivo, pueden asimilarse a las razones excepcionales no relacionadas con la trabajadora, y que constituirían una excepción a la prohibición de despedir a una trabajadora embarazada. A este respecto, reafirmando su propia interpretación más favorable frente a la más

\footnotetext{
${ }^{16}$ Este es el contenido de la parte dispositiva de la Sentencia del TJUE: "1) El artículo 10, punto 1, de la Directiva 92/85/CEE del Consejo, de 19 de octubre de 1992, relativa a la aplicación de medidas para promover la mejora de la seguridad y de la salud en el trabajo de la trabajadora embarazada, que haya dado a luz o en período de lactancia (décima Directiva específica con arreglo al apartado 1 del artículo 16 de la Directiva 89/391/CEE), debe interpretarse en el sentido de que no se opone a una normativa nacional que permite el despido de una trabajadora embarazada con motivo de un despido colectivo, en el sentido del artículo 1, apartado 1, letra a), de la Directiva 98/59/CE del Consejo, de 20 de julio de 1998, relativa a la aproximación de las legislaciones de los Estados miembros que se refieren a los despidos colectivos.

2) El artículo 10, punto 2, de la Directiva 92/85 debe interpretarse en el sentido de que no se opone a una normativa nacional que permite al empresario despedir a una trabajadora embarazada en el marco de un despido colectivo sin comunicarle más motivos que los que justifican ese despido colectivo, siempre y cuando se indiquen los criterios objetivos que se han seguido para la designación de los trabajadores afectados por el despido.

3) El artículo 10, punto 1, de la Directiva 92/85 debe interpretarse en el sentido de que se opone a una normativa nacional que no prohíbe, en principio, con carácter preventivo el despido de una trabajadora embarazada, que haya dado a luz o en período de lactancia, y que establece únicamente, en concepto de reparación, la nulidad de ese despido cuando sea ilegal.

4)El artículo 10, punto 1 , de la Directiva 92/85 debe interpretarse en el sentido de que no se opone a una normativa nacional que, en el marco de un despido colectivo a efectos de la Directiva 98/59, no establece ni una prioridad de permanencia en la empresa ni una prioridad de recolocación en otro puesto de trabajo, aplicables con anterioridad a ese despido, para las trabajadoras embarazadas, que hayan dado a luz o en período de lactancia, sin que se excluya, no obstante, la facultad de los Estados miembros de garantizar una mayor protección a las trabajadoras embarazadas, que hayan dado a luz o en período de lactancia".
} 
restrictiva procedente de la Unión Europea ${ }^{17}$, el Comité recuerda que el artículo $8 \$ 2$ solo autoriza el despido de una trabajadora durante su embarazo o permiso de maternidad en ciertos casos, en particular cuando exista una falta grave que justifique rescisión del contrato de trabajo, cuando la empresa cese su actividad o cuando expire el término previsto en el contrato de trabajo. Sin embargo, estas excepciones deben ser objeto de una interpretación estricta por parte del CEDS. En virtud de ello, el CEDS toma nota de que el despido de una empleada durante su permiso de maternidad por otros motivos, como los despidos colectivos, aunque la empresa no haya interrumpido sus actividades, suscita cuestiones serias de compatibilidad con el artículo 8\$2, concluyendo así la violación de dicha disposición.

A mayor abundamiento, el CEDS advierte sobre otra posible conculcación del artículo $8 \$ 2$ si en el próximo ciclo no se acredita el alcance garantista de la reparación en caso de despido ilegal. Efectivamente, el CEDS lamenta que en el informe del Gobierno español no se atienda el requerimiento de información sobre situaciones en las que no fue posible la readmisión y los detalles de la compensación susceptible de otorgarse en caso de despido ilegal para evitar toda discriminación por razón de embarazo o maternidad a la luz del artículo 55.6 del Estatuto de los Trabajadores y de los artículos 113 y 286.2.b) de la Ley reguladora de la jurisdicción social. Desde este prisma, el CEDS observa que, en caso de despido ilegal de una empleada durante su embarazo o permiso de maternidad, la legislación nacional debe prever soluciones apropiadas y efectivas, siendo la readmisión la regla y, excepcionalmente, si la reincorporación no resulta factible (por ejemplo, en caso de cese de actividad de la empresa) o si la persona interesada no lo desea, debe otorgarse una compensación suficiente que sea disuasoria para el empleador y totalmente reparadora para la víctima del despido.

Otra nueva conclusión negativa (que, en cambio, fue positiva en las precedentes conclusiones de 2015) adoptada por el CEDS tiene que ver con el artículo $8 \$ 3$ en materia de derecho de las asalariadas a la protección, incluidas las pausas para lactancia. En concreto, en las conclusiones anteriores [Conclusiones XIX-4 (2011) y XX-4 (2015)] el CEDS solicitó al Gobierno que confirmara que se abonan las pausas de lactancia a las que tienen derecho las trabajadoras del sector público. Como quiera que no ha mediado respuesta por parte de las autoridades españolas, además de renovarse el requerimiento, el CEDS decide ya concluir que "la situación en España no es conforme el artículo $8 \$ 3$ de la Carta de 1961, por cuanto no se ha acreditado que las mujeres

\footnotetext{
17 Como bien ha advertido C. SALCEDO BELTRÁN ("Crónica Europea. La crítica situación de los derechos sociales de la infancia, de las familias y de los migrantes: Conclusiones 2019 del Comité Europeo de Derechos Sociales", ya cit.), la interpretación del CEDS "no se ve afectada por la legitimidad que les dio la sentencia del TJUE de 22 de febrero de 2018 (asunto C-103/16 Jessica Porras Guisado/Bankia, S.A., Fondo de Garantía Salarial y otros), probando, de nuevo, los diferentes estándares de protección y la inexistencia de presunción de conformidad de una norma o práctica amparada desde el punto de vista del derecho comunitario europeo (es decir, el CEDS no acepta una presunción de conformidad del Derecho de la UE con respecto a la CSE similar a la que sí acepta el TEDH con relación al CEDH, conocida como "doctrina Bosphorus"), que ya había aclarado en Confédération générale du travail de Suède (LO) et Confédération générale des cadres, fonctionnaires et employés (TCO) contra Suecia, reclamación $\mathrm{n}^{\circ}$ $85 / 2012$, decisión de fondo de 3 de julio de 2013)" (p. 911).
} 
empleadas en la función pública disfruten del derecho a pausas de lactancia remuneradas".

Por otro lado, la siguiente conclusión de no conformidad, en este caso respecto al artículo 16 (a tenor del cual los Estados Partes "se comprometen a fomentar la protección económica, jurídica y social de la familia, especialmente mediante prestaciones sociales y familiares, disposiciones fiscales, apoyo a la construcción de viviendas adaptadas a las necesidades de las familias, ayuda a los recién casados o por medio de cualesquiera otras medidas adecuadas") no es novedosa, por cuanto una vez más ha quedado acreditado que "el nivel de las prestaciones familiares no es adecuado, pues no representa un complemento de renta significativo". En efecto, en cuanto al nivel de las prestaciones familiares, en su conclusión anterior [Conclusiones XX-4 (2015)], el CEDS consideró que la situación era contraria al artículo 16 porque "las prestaciones familiares no son de un montante suficiente para un número significativo de familias". A tal efecto, en el ciclo sometido a control en 2019 el CEDS toma nota de que, según el MISSOC (Sistema de Información Mutua sobre la Protección Social), las asignaciones familiares ascendieron a 24,25€ en 2017 por cada hijo a cargo. Según EUROSTAT, la renta mediana ajustada era de 1.183,91 $€$ por mes. En consecuencia, el CEDS observa que esas asignaciones familiares representan el $2 \%$ de la renta mensual mediana ajustada.

El CEDS toma en consideración los comentarios formulados por la Confederación Sindical de Comisiones Obreras (CCOO) y la Unión General de Trabajadores de España (UGT), según los cuales la principal prestación familiar en el sistema español de protección social consiste en una asignación por hijo a cargo que perciben casi 800.000 familias y que ha quedado congelado a $291 €$ por año. Dicha prestación es claramente insuficiente y no resuelve el grave problema de la pobreza infantil en España, que ha empeorado como resultado de la crisis económica. Según los últimos datos disponibles, las familias con hijos a cargo tienen más probabilidades de contar con una renta por debajo del umbral de pobreza, con tasas de pobreza que oscilan entre el $24 \%$ para familias encabezadas por dos adultos hasta el $41 \%$ para familias monoparentales (la mayoría de las cuales vienen constituidas por madres solteras). El CEDS hace notar asimismo que, en su respuesta, el Gobierno indica que el Real Decreto-ley 8/2019, de 8 de marzo, de medidas urgentes de protección social y de lucha contra la precariedad laboral en la jornada de trabajo, que entró en vigor el 1 de abril de 2019 y ha elevado la prestación por hijo a cargo a $341 €$ por año, y a $588 €$ anuales para familias que vivan en la pobreza extrema, estimándose el coste de este aumento en 142 millones de euros para 2019. En cualquier caso, el CEDS requiere información actualizada de esos montantes de prestaciones familiares y, para las conclusiones 2019, reitera su conclusión de violación del artículo 16 CSE, sin perjuicio del impacto futuro, no únicamente de ese Real Decretoley 8/2019, sino del más reciente y publicitado Real Decreto-ley 20/2020, de 29 de mayo, por el que se establece el ingreso mínimo vital.

Finalmente, las otras tres conclusiones de violación se reconducen a diversos apartados del artículo 19 CSE (concretamente los apartados 4, 6 y 10) que 
constituyen una nueva infracción (en el supuesto del apartado 4) o una reiteración de sendas conculcaciones verificadas en las precedentes Conclusiones de 2015 (en el caso de los apartados 6 y 10). No obstante, antes de analizar esas tres violaciones, debemos congratularnos por haberse revertido la preocupante situación que se verificó con respecto al apartado 1, que condujo al CEDS a una conclusión de vulneración por no haberse acreditado la adopción de medidas suficientes "para luchar contra la propaganda engañosa en materia de emigración e inmigración”, especialmente para combatir la difusión de estereotipos negativo. Para ello, el CEDS había acudido a las constataciones y observaciones de otros organismos de derechos humanos, tanto de la ONU (en concreto, del informe del Relator especial sobre las formas de racismo, presentado a la $23^{a}$ sesión del Consejo de Derechos Humanos el 6 de junio de 2013) como del Consejo de Europa (en particular, del $4^{\circ}$ informe de la Comisión Europea contra el Racismo y la Intolerancia, ECRI, adoptado en 2010), de donde se desprendió, entre otros extremos, que la legislación española antidiscriminatoria no era efectiva ni suficientemente invocada ante los tribunales; con análoga filosofía, el CEDS trajo a colación asimismo su jurisprudencia elaborada en el marco del procedimiento de reclamaciones colectivas (por ejemplo, la decisión de fondo de 25 de junio de 2010 sobre la reclamación no 58/2009, COHRE c. Italia), con objeto de alertar sobre el peligro de que las declaraciones de actores de la vida pública puedan crear un clima de discriminación, por lo que "debe existir un sistema eficaz de vigilancia de los discursos discriminatorios, racistas o que inciten al odio, en particular en la esfera pública”.

Por otra parte, la violación del artículo $19 \S 3$ CSE constatada en 2015 ha pasado a ser una conclusión de aplazamiento en 2019. En 2015, la vulneración se basó en que "no ha quedado acreditado que haya una cooperación suficiente entre los servicios sociales de España y de los países de emigración y de inmigración". Para alcanzar dicha conclusión, el CEDS advirtió no obstante que no es preciso que se suscriban acuerdos formales, sobre todo si los flujos migratorios no son importantes en un país dado, bastando en tal caso una "colaboración práctica, en función de las necesidades", esto es, "que la colaboración entre los servicios sociales pueda adaptarse en función de la amplitud de los movimientos migratorios". En todo caso, el CEDS llegó a la conclusión negativa por el déficit de información suministrado por el Gobierno español, observando que esa información es relevante en situaciones relativas, por ejemplo, a un trabajador migrante que haya dejado a su familia en el país de origen y desee enviarle dinero o deba ser contactado por razones familiares, así como a un trabajador migrante que haya regresado al país y deba reclamar los salarios o prestaciones que no le hayan sido abonados. Ahora bien, el CEDS no pasa directamente a una conclusión positiva del citado artículo $19 \S 3$ CSE porque requiere información adicional importante para el próximo informe, al menos en lo atinente a dos aspectos: de un lado, ejemplos de colaboración de las Comunidades Autónomas con los principales países de emigración e inmigración, indicando los servicios implicados y la forma y naturaleza de los contactos e intercambios de información; y, de otro lado, datos sobre los trabajadores españoles que residan en el territorio de otros Estados Partes para comprobar cómo esa ciudadanía española en el exterior recibe asistencia ante eventuales problemas profesionales, familiares y de 
seguridad social.

Veamos, pues esas tres violaciones restantes. En cuanto a la nueva violación del artículo 19\$4 CSE, tal conclusión de no conformidad se basa en que "no se ha acreditado que la ausencia de discriminación de Derecho o de hecho esté garantizada con respecto al disfrute por parte de los trabajadores extranjeros de las ventajas ofrecidas por los convenios colectivos". A este respecto, el CEDS recuerda que esta disposición requiere que los Estados eliminen toda discriminación jurídica y fáctica con respecto a la afiliación a organizaciones sindicales y al disfrute de las ventajas ofrecidas por la negociación colectiva, incluido el derecho a ser miembro fundador de un sindicato y el acceso a las funciones administrativas y de gestión de los sindicatos. En su conclusión anterior [Conclusiones XX-4 (2015)], el CEDS observó que, de conformidad con el artículo 11 de la Ley Orgánica 4/2000: a) los extranjeros tienen derecho a sindicarse libremente o a afiliarse a una organización profesional, en las mismas condiciones que los trabajadores españoles; b) los extranjeros pueden ejercer el derecho de huelga en las mismas condiciones que los españoles. El caso es que, desde 2011 (ver Conclusiones XIX-4), el CEDS ha venido solicitando información sobre el estado de la sindicación de los trabajadores extranjeros y sobre la ausencia de discriminación de jure y de facto con respecto al disfrute por parte de dichos trabajadores foráneos de las ventajas ofrecidas por convenios colectivos. Como el Gobierno español ha persistido en no facilitar dicha información, el CEDS reitera su conclusión de violación del artículo 19§4. Con carácter adicional, advierte sobre una posible violación de dicha disposición en el próximo ciclo de control si no se facilitare información sobre el estatuto jurídico de los trabajadores desplazados desde el extranjero a España.

A continuación, la repetición de la vulneración del artículo $19 \S 6$ CSE ha respondido a los dos siguientes motivos: "- las prestaciones de asistencia social están excluidas del cálculo de los ingresos del trabajador a los efectos de reunificación familiar; - no se ha establecido que el requisito de que el migrante tenga una vivienda adecuada para traer a su familia, o que las restricciones linguiísticas o sanitarias no sean tan restrictivas como para impedir la reunificación familiar". En relación con ello, el CEDS recuerda su conclusión precedente de 2015, en la que ya constató que "ni la legislación ni la práctica prevén la reagrupación familiar de los hijos de los trabajadores migrantes que tengan entre 18 y 21 años cuando no sean discapacitados o no necesiten la asistencia de un tercero en razón de su estado de salud". Y, en tal sentido, el CEDS ya apuntó que, a los efectos de dicha disposición, los términos "familia del trabajador migrante" deben ser interpretados como inclusivos, al menos, de la esposa del trabajador y sus hijos menores de 21 años que estén a su cargo; a lo que agregó el propio CEDS en 2015 que, "teniendo en cuenta la obligación enunciada en el artículo $19 \$ 6$ de facilitar en la medida de lo posible la reagrupación familiar, los Estados Partes no deben aplicar esas exigencias de manera tan general como para excluir la posibilidad de prever derogaciones relativas a algunas categorías de casos, o de tener en cuenta circunstancias personales. En opinión del Comité, es necesario que, en la práctica, las autoridades encargadas de la emisión de 
los permisos de estancia tras las solicitudes de reagrupación familiar tengan en cuenta el hecho de que el principio de reagrupación familiar no es sino un aspecto del reconocimiento en la Carta (artículo 16) de la obligación de los Estados de asegurar la protección social, jurídica y económica de la familia. Por consiguiente, la aplicación del artículo $19 \S 6$ debe tener en cuenta en todo caso la necesidad de cumplir con dicha obligación".

Con tales parámetros, en lo concerniente a la toma en consideración de las prestaciones de asistencia social para el cómputo de las rentas de la persona trabajadora migrante y de la vivienda adecuada a efectos de reagrupación familiar, el CEDS pondera las estadísticas ofrecidas por el informe gubernamental, el cual muestra que durante el período de referencia se rechazaron entre 2.210 y 2.889 solicitudes cada año por tales motivos (recursos insuficientes o alojamiento inadecuado). Por el contrario, se reprocha por el CEDS que no se den detalles sobre cómo se establecen y motivan los criterios de rechazo, lo que conduce a reiterar el incumplimiento del artículo $19 \S 6$ sobre ambos aspectos. Análogo reproche dirige el CEDS a la circunstancia de que el informe gubernamental no contenga una relación exhaustiva y motivada de las restricciones fundadas en criterios linguiísticos (pruebas de aptitud idiomática y de integración lingüística) y sanitarios (la jurisprudencia del CEDS exige que se trate realmente de enfermedades específicas que comporten una gravedad tal que ponga en peligro la salud pública), con objeto de tales restricciones no comporten el riesgo de obstaculizar, en lugar de facilitar, la reunificación familiar. Como garantía adicional, el CEDS hace notar que los miembros de la familia del trabajador o trabajadora migrante que han obtenido la reagrupación no puede ser expulsados como consecuencia de la expulsión del propio trabajador o trabajador, dado que disfrutan de un derecho autónomo a permanecer en el territorio nacional del Estado Parte; razón por la cual, el CEDS requiere que se le informe en el próximo ciclo de control sobre si es posible tomar una decisión de expulsión de los familiares de la persona trabajadora migrante que haya perdido su derecho de estancia y, en caso afirmativo, bajo qué condiciones.

Por último, la conclusión de vulneración del artículo 19\$10 CSE (igualdad de trato para los trabajadores migrantes por cuenta propia) aparece asociada a la violación de los otros dos apartados, de tal suerte que "la situación de España no es conforme al artículo 19.10 de la Carta de 1961, pues los motivos de no conformidad basados en los apartados 4 y 6 del artículo 19 se aplican igualmente a los trabajadores migrantes autónomos". Cabalmente, sobre la base del contenido del informe gubernamental, el CEDS observa que persiste la ausencia de discriminación entre los trabajadores migrantes y los trabajadores migrantes autónomos. No obstante, en el caso del artículo 19§10, una conclusión de incumplimiento de cualquiera de los otros párrafos del propio artículo 19 normalmente conduce a una conclusión de incumplimiento desde el punto de vista de este párrafo, porque los motivos de incumplimiento se aplican igualmente a los trabajadores autónomos o por cuenta propia. Esto es así cuando no media discriminación o diferencia de trato. En consecuencia, tras llegar a una conclusión de no conformidad en virtud de los artículos $19 \S 4$ y 19§6, concluye asimismo que la situación en España no es conforme con 
el artículo $19 \S 10$ de la Carta de 1961.

\section{LA JURISPRUDENCIA REFERENTE AL MECANISMO DE RECLAMACIONES COLECTIVAS DURANTE 2018 Y 2019}

\section{Observaciones preliminares}

El primer elemento que llama la atención, en lo que atañe al procedimiento de reclamaciones colectivas durante los años 2018 y 2019, es que ha habido un importante incremento de ellas, tanto en el número de registros como en el de resoluciones de fondo por parte del CEDS. Entre estas últimas, sin perjuicio de algunos apuntes en torno a la formación profesional y a la protección social, de un lado ha seguido consolidando su línea jurisprudencial sobre las situaciones de vulnerabilidad (no evolucionando, en cambio, en el desarrollo del Derecho antidiscriminatorio con apoyo en la cláusula de igualdad del Preámbulo de la CSE de 1961 o del artículo E de la CSE revisada de 1996) y, de otro, su interpretación en torno a determinados derechos laborales y, sobre todo, sindicales y de acción colectiva.

Por otra parte, en esos dos años se han dictado asimismo cuatro decisiones de admisibilidad; lo cual, si bien sigue constituyendo un número exiguo, eleva el porcentaje de operatividad del filtro de la (in)admisibilidad. Como quiera que las decisiones de fondo serán reseñadas con mayor detalle en los apartados siguientes con los bloques jurisprudenciales correspondientes, ahora procede acercarse a esas cuatro decisiones de inadmisibilidad, alguna de las cuales llama la atención por introducir una línea formalista y rigorista que no venía caracterizando hasta ahora el modus operandi procesal del CEDS.

Semejante proceder viene ilustrado precisamente por la decisión de inadmisibilidad de 22 de marzo de 2018 de la Reclamación no 156/2017 (Federación panhelénica de jubilados de las telecomunicaciones del grupo OTE c. Grecia). Registrada el 23 de agosto de 2017, en ella el sindicato reclamante alegaba la violación del derecho a la seguridad social del artículo 12 CSE, así como del derecho de las personas mayores a una protección social del artículo 4 del Protocolo adicional de 1988, denunciando que las Leyes 4336/2015, 4387/2016 y 4472/2017 adoptadas en Grecia habrían procedido a una reducción de pensiones y prestaciones contraria a las disposiciones citadas del tratado europeo. El motivo principal hecho valer por el CEDS (§ 5 de la decisión) para inadmitir la reclamación fue que, cuando se formuló la reclamación, la Carta de 1961 y el Protocolo de 1988 ya no estaban en vigor para Grecia, dado que dicho país ya había ratificado la CSE revisada de 1996 el 18 de marzo de 2016 (en vigor para Grecia el 1 de mayo de 2016). Es cierto que el CEDS no puede erigirse en abogado de las partes procesales y suplir su eventual falta de pericia pero, realmente, resulta sencillo al CEDS considerar que se había producido un error material subsanable al referirse a las disposiciones del tratado europeo originario (CSE de 1961 y Protocolo de 1988), para entender hechas esas alegaciones a las disposiciones equivalentes de la CSE revisada de 1996; por añadidura, razones de economía procesal aconsejaban ello, para no obligar a la parte reclamante a reintroducir una nueva reclamación (en otras 
palabras, se podría haber requerido al sindicato reclamante para subsanar la demanda colectiva señalando los artículos equivalentes de la versión revisada de la 1996, en lugar de abocarla a formular otra reclamación).

Una segunda decisión de inadmisibilidad interesante fue adoptada el 22 de enero de 2019 (en ella se rechazaba también la adopción de las medidas inmediatas cautelares solicitadas, entre ellas la petición de suspensión de la aprobación de dicho Acuerdo) en la Reclamación no 163/2018 (ATTAC ry, Globaali sosiaalityö ry y Maan ystävät ry c. Finlandia), en donde las organizaciones reclamantes denunciaban que el Gobierno finlandés había puesto en peligro el respeto de los derechos garantizados por la CSE revisada (se invocaban los reconocidos en los artículos 1 a 7, 11 a 13, 20 a 24, 26 a 31 y artículo E) como consecuencia del modo en que dicho Gobierno había negociado el Acuerdo económico y comercial global (AECG/CETA), así como por el sistema jurisdiccional de las inversiones previsto en dicho Acuerdo ${ }^{18}$.

El CEDS fundamentó esencialmente su inadmisión en que el Protocolo sobre reclamaciones colectivas habilita a las organizaciones legitimadas a denunciar "una aplicación no satisfactoria de la Carta" (artículo 1) para que el CEDS determine "si la Parte Contratante denunciada ha asegurado o no de manera satisfactoria la aplicación de la disposición de la Carta invocada en la reclamación" (artículo 8\$1); por el contrario, no le corresponde "apreciar la conformidad con respecto a la Carta de cualquier tratado internacional que el Estado Parte concernido haya ratificado o afronte concluir. Tampoco le corresponde apreciar los procedimientos y procesos seguidos por los Estados Partes en la negociación de un acuerdo internacional” (§ 15). Ese enfoque es ciertamente difícil de discutir, al plantearse la reclamación con relación a la fase negociadora de un tratado (lo mismo que si se hubiera planteado con relación a un proyecto o disposición de ley) o incluso aunque se hubiera planteado frente al propio Tratado una vez ya establecido el texto y entrado en vigor; otra cuestión es someter al CEDS las disposiciones nacionales que reflejen, reproduzcan o se han eco de las disposiciones del tratado, que propiciarían eventualmente una especie de control indirecto: así lo entiende el CEDS cuando, a renglón seguido ( $\$ 16)$ advierte que "no escapa al Comité que un acuerdo comercial internacional como el AECG puede, evidentemente, tener consecuencias considerables en la puesta en práctica de los derechos sociales garantizados por la Carta; dicho lo cual, resulta imperativo, para poder válidamente pronunciarse sobre la cuestión jurídica de saber si esas consecuencias atentan contra las obligaciones derivadas de las disposiciones sustanciales de la Carta, que el problema se examine en el contexto del Derecho y de la práctica internas que puedan resultar del funcionamiento y puesta en práctica de un acuerdo como el AECG. No corresponde al Coité especular sobre la conformidad jurídica y práctica 'previsibles' o 'que puedan esperarse' con respeto a un acuerdo todavía no entrado en vigor", por todo lo cual la reclamación "no cumple las condiciones del artículo 4 " del Protocolo sobre el procedimiento de reclamaciones colectivas (§ 17).

${ }^{18}$ Se refiere, por sus siglas en inglés, al Acuerdo Integral sobre Economía y Comercio (CETA: Comprehensive Economic and Trade Agreement) entre la UE y Canadá. 
La tercera decisión de inadmisibilidad fue adoptada por el CEDS en fecha 18 de marzo de 2019, concretamente de la Reclamación no 166/2018 (Sindacato Autonomo Europeo Scuola ed Ecologia, SAESE, c. Italia). Registrada el 7 de mayo de 2018, el sindicato denunciante alegaba la violación del derecho a la salud consagrado en el artículo 11 CSE revisada, esgrimiendo que la conocida como "Ley Fornero", (Decretoley $n^{\circ}$ 201/2011, de 6 de diciembre de 2011) que procedió a la prolongación de la edad de jubilación en relación con los trabajadores de los sectores público y privado, vulneraba dicha disposición europea, en concreto, argumentaba el sindicato reclamante que, en el momento de la adopción de la reforma del régimen de jubilación del personal docente, el legislador no procedió a evaluación científica alguna sobre el estado de salud de dicha categoría profesional del ámbito de la enseñanza. La inadmisión declarada por el CEDS se basó fundamentalmente en dos motivos: de un lado, pese al ámbito en el que desarrolla su actividad representativa y sindical (a favor de los docentes de las escuelas italianas de todos los niveles, así como de las universidades, de las académicas y de los conservatorios), el CEDS no se encontraba en condiciones de determinar que el SAESE fuera un sindicato representativo en el sentido del artículo 1.c) del Protocolo sobre el procedimiento de reclamaciones colectivas, al no haber aportado la organización reclamante las informaciones necesarias para evaluar su representatividad, incluidas indicaciones sobre el número preciso de afiliados o sobre el hecho de haber llevado a cabo negociaciones colectivas por cuenta de sus miembros para concluir convenios colectivos ( $\$ 10)$. Y, de otro lado, los motivos aducidos por la entidad reclamante revelarían un alto grado de vaguedad y estarían desprovistos de elementos de prueba para poder evaluar el nexo causal entre la reforma del régimen público de pensiones y la supuesta vulneración del artículo 11 CSE, no cumpliendo con los requisitos del artículo 4 del Protocolo (§ 11).

En fin, una última decisión de inadmisibilidad, relativa al mismo país, fue adoptada por el CEDS el 6 de diciembre de 2019, en el marco de la Reclamación no 177/2019 (Associazione Medici Liberi c. Italia). Registrada el 7 de marzo de 2019, en ella la entidad reclamante alegaba la violación del derecho a la seguridad social (artículo $12 \S \S 1,2$ y 3 de la CSE revisada), denunciando que la legislación italiana no garantizaría a los médicos liberales (ejercicio privado) un nivel satisfactorio para la pensión de jubilación. De manera más precisa, la organización reclamante se queja de que la cobertura de seguridad social de los médicos ejercientes en régimen liberal viene establecida por un mecanismo de afiliación obligatoria a la caja general de la seguridad social de todos los médicos inscritos en los colegios profesionales; esto implica el pago de dos tipos de cotización (una del régimen A, que es una cotización a tanto alzado que debe pagar cualquier médico; y una del régimen $\mathrm{B}$, que se corresponde con la que debe cotizar todo médico que ejerza en el ámbito privado y tenga beneficios superiores a 4.770,00 euros anuales si tiene menos de cuarenta años u 8.809,33 euros anuales si tiene más de cuarenta años), de tal manera que si los ingresos percibidos son inferiores a los límites mencionados, la pensión del médico que ejerce en el ámbito privado quedará exclusivamente determinada por las cotizaciones a tanto alado del régimen $\mathrm{A}$, en cuyo 
caso no quedaría asegurado un nivel de vida digno al jubilarse. Ahora bien, el CEDS no entró en el fondo de la reclamación al entender, en esencia, que "Medici Liberi no ha llevado a cabo actividades susceptibles de ser consideradas como actividades sindicales esenciales, tales como participar en una negociación colectiva, convocara una huelga a concluir convenios colectivos. El Comité considera, además, que el simple hecho de que Medici Liberi haya formulado la presente reclamación no puede interpretarse en sí como tal prueba de actividad sindical. En este contexto, el Comité considera que Medici Liberi no puede ser considerado como una organización sindical en el sentido del artículo 1.c) del Protocolo" ( $\$ 11)$, siendo consecuentemente asimismo innecesario examinar si es representativo $(\S 12)$.

\section{Jurisprudencia sobre situaciones de vulnerabilidad y Derecho antidiscriminatorio}

El CEDS adoptó o publicó en 2018 y 2019 importantes decisiones de fondo en las que ha consolidado una línea jurisprudencial protectora de personas vulnerables. Ahora bien, es menester precisar que ha brindado dicha tutela sobre la base de disposiciones sustanciales, sin que por el contrario haya forjado un sólido Derecho antidiscriminatorio, puesto que no ha sacado todo el partido posible al principio de no discriminación del art. E de la CSE revisada de 1996 (o la equivalente cláusula presente en el Preámbulo de la CSE originaria de 1961).

Semejante enfoque lo ilustra la primera de esas decisiones, la adoptada el 16 de octubre de 2017 (pero hecha pública el 29 de marzo de 2018), mediante la que se pronunció sobre la admisibilidad y el fondo de la Reclamación no 109/2014 (Centro de Defensa de los Derechos de las Personas con Discapacidad Mental/Mental Disability Advocacy Center c. Bélgica), registrada el 30 de abril de 2014. En ella, la organización reclamante denunciaba la violación de los artículos 15 (derechos de las personas con discapacidad) y 17 CSE (protección social, jurídica y económica de niños y adolescentes) en relación con el derecho a una educación inclusiva de los niños con discapacidad. En su decisión de inadmisibilidad y fondo de 16 de octubre de 2017, el CEDS concluyó que se había producido una violación tanto del artículo $15 \S 1$ (por cuanto no se garantiza efectivamente en la Comunidad flamenca de Bélgica el derecho a la educación inclusiva de los niños afectados por discapacidad intelectual y no existe un recurso efectivo contra la inadmisión en el sistema general de enseñanza) como del artículo 17§2 (en razón de la inaccesibilidad para dichos niños a los centros de enseñanza y programas educativos ordinarios); por el contrario, concluyó que no hubo violación del artículo E (no discriminación) en conexión con las mencionadas disposiciones sustanciales (artículos 15 y 17), al no considerar acreditada la discriminación basada en la discapacidad y su conexión con motivos socio-económicos, por la mayor carga financiera que han de soportar las familias afectadas (por el material, el apoyo terapéutico y el propio esfuerzo adicional y dedicación temporal de los padres a esos niños).

Por otra parte, en ese mismo ámbito de protección de menores debe mencionarse 
la decisión de fondo de 24 de enero de 2018 (hecha pública el 15 de junio de 2018) de resolución de la Reclamación $\mathrm{n}^{\circ}$ 114/2015 (Comité europeo de acción especializada para el niño y la familia en su medio de vida, EUROCEF, c. Francia) en la que se alega la violación de diversas disposiciones de la CSE (artículos 7, 11, 13, 14, 17, 30 y 31, solos o en combinación con el artículo E) en relación con la acogida de menores extranjeros no acompañados (declarada admisible el 30 de junio de 2015). Pues bien, en su decisión de fondo, el CEDS concluyó la violación del artículo $7 \$ 10$ (debido al alojamiento inapropiado de dichos menores y quedar expuestos a convertirse "niños de la calle"), de los artículos $11 \S 1$ y $13 \S 1$ (a causa del deficitario acceso a la salud y a la asistencia social, respectivamente, de esos MENA), del artículo $17 \S 1$ (por las carencias del dispositivo nacional de acogimiento y alojamiento de los MENA, su detención en establecimientos inadecuados, el uso inadaptado e ineficaz de los tests óseos para determinar la edad y la inefectiva de los recursos jurídicos en la materia), del artículo $17 \S 2$ (por el deficitario acceso a la educación de los MENA de entre 16 y 18 años) y del artículo 31 2 (de nuevo, por la deficitaria provisión de alojamiento de dichos menores). Por el contrario, el CEDS desestimó por 11 votos contra 4 que hubiera violación del artículo 30 (protección contra la pobreza y la exclusión social), pese a reconocer "que la situación de algunos menores podría exponerles a pobreza y exclusión social” (§185), una paradoja que pone de manifiesto argumentadamente en su voto particular discrepante Petros Stangos en clave de lucha contra la infantilización de la pobreza.

Una tercera resolución importante tiene que ver igualmente con la protección del interés superior del menor, concretamente la decisión de fondo de 5 de diciembre de 2017 (hecha pública el 16 de abril de 2018) sobre resolución de la Reclamación no 119/2015 (Foro europeo de las personas de etnia gitana e itinerantes c. Francia); en ella se denunciaba básicamente la violación de los artículos $10 \S \S 3$ y 5, 16, 17§2, 30 y 31 CSE revisada, de modo autónomo o en conjunción con la cláusula de no discriminación del artículo E, especialmente en lo que concierne al acceso a la educación y la formación profesional de los niños de etnia gitana. El CEDS acogió la mayor parte de esas denuncias, determinando la violación del artículo $17 \S 2$ (solo y en combinación con el artículo E), así como de esa misma cláusula antidiscriminatoria (artículo E) en combinación con los artículos $10 \S \S 3$ y 5, 17§2, 30 y 31, como consecuencia de esa exclusión de los citados menores de la escolarización obligatoria e inestabilidad de las condiciones de vida en los campamentos gitanos, de las discriminaciones (de orden administrativo, social y económico), de las evacuaciones sucesivas que comportan segregación y ausencia de inclusión en el tejido social y en el sistema educativo, y de las condiciones habitacionales irrespetuosas con la dignidad. La no violación del artículo E en conjunción con el artículo 16 se determina por el CEDS por la ausencia de elementos acreditativos de discriminación que conduzca a privación de las prestaciones sociales y familiares a que tendrían derecho las familias de esos menores.

En el mismo terreno, cabe mencionar la decisión de fondo de $\mathbf{1 6}$ de octubre de 2018 (publicada el 23 de marzo de 2019), de resolución de la Reclamación $\mathbf{n}^{\circ}$ 
121/2016 (Equal Rights Trust, ERT, c. Bulgaria); en ella se denunciaba la violación de los artículos 12§3, 16 y 17§2, considerados autónomamente o en combinación con el artículo E de la CSE revisada, como consecuencia de la Ley búlgara sobre las prestaciones familiares para niños (por la modalidad de pago de esas prestaciones, por la posible suspensión de ellas en caso de absentismo escolar e incluso por el fin de la percepción si el niño se convierte en padre, aspectos que podrían constituir una discriminación racial en perjuicio de la comunidad gitana). En su decisión de fondo, tras recalificar las alegaciones y descartar la pertinencia de la aplicación de los artículos $12 \S 317 \S 2$, reconduciendo la problemática a la protección de la familia del artículo 16), el CEDS declaró que hubo violación del artículo 16 por dos motivos (con relación a la suspensión o supresión de las prestaciones familiares mensuales si el menor deja de asistir a la escuela, así como si la supresión de ellas de produce si el niño se convierte en padre), además de una violación del propio artículo 16 en conjunción con el artículo $\mathrm{E}$ (discriminación indirecta, con impacto desproporcionado por los dos citados motivos, en perjuicio de la comunidad gitana, y más particularmente de los menores de etnia gitana). Siendo relevante este pronunciamiento, cabe lamentar que el CEDS no haya incidido (y ni siquiera mencionado) en la doctrina de las obligaciones positivas que pesan sobre las autoridades públicas (y no solamente sobre los padres) en materia de aseguramiento de la escolaridad obligatoria y frente al absentismo escolar (a diferencia de lo que sí hizo el CEDS en su decisión de fondo de 19 de marzo de 2013 sobre la Reclamación nº 82/2012, EUROCEF c. Francia).

Una quinta resolución tiene que ver asimismo con personas de etnia gitana y, más concretamente con múltiple discriminación (al quedar involucrada asimismo la desigualdad sufrida por las mujeres romaníes): se trata de la decisión de fondo de 5 de diciembre de 2018 (hecha pública el 19 de abril de 2019), que resolvió la reclamación $n^{\circ}$ 151/2017 (ERRC, European Roma Rights Centre/Centro Europeo de Derechos de las Personas de Etnia Gitana c. Bulgaria); en ella, la organización reclamante reprochaba a Bulgaria que no haya adoptado acciones suficientes para poner fin a la segregación racional en cuanto al acceso de las mujeres de etnia gitana a los cuidados y tratamientos de maternidad, y al efecto pernicioso en dicho ámbito de la falta de un seguro médico para dichas mujeres, todo ello con presunta violación del derecho a la protección de la salud del artículo 11 y del derecho a la asistencia social y médica del artículo 13 CSE, autónomamente o en combinación con el artículo E (no discriminación). En su decisión de fondo, el CEDS acogió la vulneración del artículo E combinado con el artículo $11 \S 1$ (tras descartar que el artículo 13 suscitara cuestiones susceptibles de un análisis diverso) en lo relativo a la exclusión de las mujeres gitanas a un seguro médico y a la atención sanitaria a la maternidad, desestimando por el contrario que hubiera violación de esas mismas disposiciones por supuestas prácticas de segregación racial en los hospitales públicos materno-infantiles en la atención al parto.

En cierto modo relacionada con la precedente, debe mencionarse la más reciente decisión de fondo de 11 de septiembre de 2019 (publicada el 4 de febrero de 2020) 
mediante la que se resuelve la Reclamación colectiva $n^{0}$ 139/2016 [Central Union for Child Welfare (CUCW) c. Finlandia]; la organización reclamante denunciaba que la nueva legislación en vigor desde el 1 de agosto de 2016 discriminaba a padres y madres desempleados y sus hijos e hijas en materia de maternidad, paternidad y permisos, en función del municipio en el que se viva, todo ello con vulneración de los artículos 16, 17 , 27 y E de la CSE revisada. En concreto, acogiendo los motivos impugnatorios, el CEDS concluyó la violación del artículo E (no discriminación) en combinación con los artículos 16 y $17 \S 1$ a) (protección de la familia y de los menores, respectivamente), así como del artículos 27§1.c) CSE revisada (conciliación de la vida laboral y familiar) como consecuencia de la citada modificación introducida (bajo el pretexto de las medidas de austeridad anticrisis) con efectos 1 de agosto de 2016 en la Ley sobre educación y guarderías para niños en edad preescolar, al establecer restricciones en el acceso a la gratuidad de dicho servicio en detrimento de las familias más vulnerables o con mayores cargas sociales (con progenitores en situación de desempleo o disfrute de permiso de maternidad, paternidad o parental) y de manera asimétrica en función del municipio de residencia. Es curioso que, en el supuesto de la violación del artículo 27§1.c), pese a reconocer el propio CEDS que sigue un razonamiento similar al que le ha conducido a la violación conjunta del artículo $17 \S 1 . a)$ y del artículo E (§94), no extraiga a renglón seguido consecuencia similar de violación asimismo conjunta del artículo 27§1.c) con el artículo E (§96), pese a estimar explícitamente "que el Gobierno no ha aportado ninguna justificación objetiva y razonable de esta diferencia de trato entre progenitores en paro o en permiso y progenitores trabajadores, en cuanto al acceso a los servicios de guardería, lo que penaliza a quienes más necesitan de ayuda para que puedan incorporarse o retornar a la vida activa" ( $\$ 95$ ), todo lo cual va en detrimento del desarrollo del Derecho antidiscriminatorio en un campo tan fundamental y aristas de igualdad de género como la conciliación de la vida familiar y profesional.

No obstante lo anterior, desde la óptica de la ejecución de esta decisión de fondo, en un apartado de observaciones finales el propio CEDS incorpora un apartado en el que "toma nota de la intención del Gobierno de modificar la ley sobre educación y guarderías para niños en edad preescolar y de restablecer el derecho subjetivo anterior de los niños a una educación y a una protección preescolar a tiempo completo. El Comité considera que, si la nueva ley entra en vigor y es correctamente puesta en práctica, la situación ya no será de violación del artículo E leído en combinación con el artículo 17§1.a), del artículo 27§1.c) y del artículo E leído en combinación con el artículo 16 de la Carta" (§ 115). De hecho, es menester mencionar que, con la intención de dar cumplimiento a esa decisión de fondo de 11 de septiembre de 2019, el Gobierno condenado anunció en su web oficial inmediatamente después de publicada la decisión ${ }^{19}$, que va a modificar la ley controvertida para que la medida discriminatoria y violatoria quede suprimida a partir del 1 de agosto de 2020 .

19 https://valtioneuvosto.fi/en/article/-/asset publisher/the-european-committee-on-social-rights-made-aruling-against-finland-on-restricting-the-right-to-early-childhood-education-and-care?fbclid=IwAR2m3d7YV168M5dcdcZcHgPnYU VI6Ln8RabTWbKX-v1Ejc1CMIxFbRvEA. 
La jurisprudencia sobre situaciones de vulnerabilidad se ha visto completada con una resolución sobre un terreno novedosamente planteado en el marco del procedimiento de reclamaciones colectivas, en relación con la no discriminación por razón de orientación sexual e identidad de género. Se trata, particularmente de la Reclamación n⿳ 117/2015 (Transgender-Europe and ILGA-Europe c. República Checa), en donde las organizaciones litigantes denunciaban la violación del derecho a la salud (artículo 11, solo y en conexión con el principio de no discriminación que figura en el Preámbulo de la Carta de 1961, dado que la República Checa no ha aceptado la versión revisada de 1996 en donde se incorporó el artículo E) como consecuencia de la obligación legal de esterilización impuesta a las personas que deseen cambiar sus documentos personales con el fin de reflejar su identidad de género. En su decisión de fondo de 15 de mayo de 2018 (hecha pública el 1 de octubre de 2018), el CEDS concluyó efectivamente que hubo violación del artículo $11 \S 1$, no acogiendo en cambio la denuncia de discriminación. Lo cierto es que el CEDS, para concluir dicha violación del derecho a la salud, se apoya asimismo en las sinergias con otras instancias e instrumentos internacionales de protección de derechos humanos, tanto del Consejo de Europa (por ejemplo, SSTEDH Christine Goodwin c. Reino Unido de 11 de julio de 2002, Van Kück c. Alemania de 12 de junio de 2003, Y.Y. c. Turquía de 10 de marzo de 2015, o A.P, Garçon et Nicot c. Francia de 6 de abril de 2017, así como informes o documentos temáticos de la Comisión Europea contra el Racismo y la Intolerancia -ECRI- o del Comisario Europeo de Derechos Humanos-) como de otros foros regionales (verbigracia, la Opinión Consultiva OC-24/17, de 24 de noviembre, de la Corte Interamericana de Derechos Humanos) y de Naciones Unidas (entre otros, algunas Observaciones generales -n ${ }^{\circ} 14$ de 2000 o no 22 de 2016- del Comité DESC, la Recomendación General $n^{\circ} 24$ del Comité para la eliminación de la discriminación contra la mujer, o informes de las Relatorías especiales para la mejora del derecho a la salud o contra la tortura y otras penas o tratos crueles, inhumanos y degradantes).

Con esta base argumental, el propio CEDS concluye (\$86) que las condiciones impuestas en República Checa para el reconocimiento de la identidad de género de una persona transgénero adulteran el consentimiento libre e informado $\mathrm{y}$, semejante obligación, constituye un atentado a la integridad física que opera en contra de la noción de dignidad humana y, en consecuencia, es incompatible con el derecho a la salud garantizado por el artículo $11 \S 1$ CSE. Sin embargo, el CEDS llega asimismo a la siguiente consideración conclusiva paradójica (§88): “aun planteándose cuestiones de discriminación en la reclamación, puesto que la misma ha sido formulada en virtud de la Carta de 1961, el Comité no examinará la reclamación a la luz del Preámbulo de la Carta de 1961", lo cual, dicho sea de paso, va flagrantemente contra su propia jurisprudencia (baste mencionar la decisión de fondo de 30 de maro de 2009 de resolución de la Reclamación no 45/2007, INTERIGHTS c. Croacia), como de modo acertado expone críticamente (reprochando las "consideraciones formalistas" de la mayoría) en su voto particular concurrente Karin Lukas.

Finalmente, el presente bloque referente a situaciones de vulnerabilidad cabe 
cerrarlo con una resolución referente a las personas mayores. Se trata de la decisión de fondo de 22 de mayo de 2019 (hecha pública el 11 de septiembre de 2019), sobre la Reclamación no 145/2017 (FIAPA, Fédération internationale des associations de personnes âgées c. Francia), en donde la organización denunciante (invocando los artículos 23 y E de la CSE revisada) alegaba que la legislación francesa en materia de represión del abuso fraudulento del estado de vulnerabilidad y debilidad de las personas mayores (en particular, el artículo 223-15-2 del Código penal, introducido mediante Ley $\mathrm{n}^{\circ}$ 2001-504 de 12 de junio de 2001, modificada por Ley n ${ }^{\circ} 2009-256$ de 12 de mayo de 2009), tal como es interpretada por las jurisdicciones internas, no les aseguraría el ejercicio efectivo de su derecho a una protección social como prevén las disposiciones citadas. En cambio, el CEDS desestima la reclamación, concluyendo que no hay violación alguna, tras entender que no se ha acreditado que la citada normativa penal, a la luz de su interpretación por la jurisprudencia del propio CEDS y por la jurisprudencia nacional y del TEDH (se traen a colación diversas sentencias de las Salas de lo Penal y de lo Social de la Corte de Casación francesa, §§ 14-19, en conexión con las SSTEDH Heinish c. Alemania de 21 de julio de 2011 y Zehentner c. Austria de 16 de julio de 2009), no ofrezca un marco suficiente para determinar, caso por caso, si la edad genera un estado de ignorancia o de debilidad como criterio de vulnerabilidad ( $\$ 54-55)$, sin que a tenor de la jurisprudencia del TEDH la edad avanzada pueda ser considerada por sí sola como determinante de la vulnerabilidad de una persona $(\$ 56)$.

\section{Jurisprudencia sobre aspectos referentes a formación profesional y protección social bajo diversas dimensiones (igualdad y libertad) y en diversos sectores}

En este bloque jurisprudencial conviene incluir una interesante decisión de fondo del CEDS que, adoptada a finales de 2016 y publicada a principios de 2017, no llegó a incluirse en la crónica de 2017, por lo que se incorpora ahora. Se trata de la decisión de fondo de 18 de octubre de 2016 (hecha pública el 15 de marzo de 2017), de resolución de la Reclamación no 105/2014 (Asociación Sindical “La Voce dei Giusti” c. Italia), en donde se denunciaba la vulneración del derecho a la formación profesional de determinadas categorías de personal docente (se invocan los artículos 10 y E de la Carta Social revisada). En particular, según la organización reclamante, la normativa italiana que determina las condiciones de obtención de la especialización para clases de apoyo o de educación especial, impediría a los docentes interinos que figuran en la conocida como "tercera categoría" (III fascia) en las bolsas de trabajo el que puedan acceder libremente a los cursos de formación pertinente, a diferencia de los docentes titulares de la habilitación para enseñar (abilitazione), con la consiguiente discriminación entre ambas categorías.

El CEDS, efectivamente, concluyó que había una violación del artículo E en conjunción con el artículo $10 \S 3$ a) y b) de la CSE revisada, por cuanto dichos docentes integrados en la tercera categoría de las bolsas de trabajo serían víctimas de discriminación indirecta en el acceso a la formación especializa para esa enseñanza de apoyo o educación especial. Para llegar a dicha conclusión, el CEDS tomo en 
consideración no únicamente la normativa y la jurisprudencia nacionales, sino asimismo otros instrumentos internacionales (por ejemplo, la Directiva 2005/36/CE del Parlamento Europeo y del Consejo, de 7 de septiembre de 2005, relativa al reconocimiento de cualificaciones profesionales). En suma, el CEDS considera que esas restricciones al acceso a la formación profesional de las distintas categorías de docentes (titulares e interinos) es desproporcionada, sin perjuicio de que Italia puede instaurar un sistema más favorable de reclasificación y promoción profesionales (en función, además, de la supresión de puestos o la creación de un número menor de plazas en el sistema educativo) para quienes hayan obtenido la habilitación y ostenten la titularidad.

En cierta conexión con la anterior, el CEDS dictó otra decisión más reciente, a principios de enero de 2018 y contra el mismo país, pero en este supuesto con conclusión desestimatoria. En efecto, se trata de la decisión de fondo de 24 de enero de 2018 (hecha pública el 29 de junio de 2018) de resolución de la Reclamación colectiva $\mathbf{n}^{\mathbf{0}}$ 113/2014 (Unione Italiana del Lavoro U.I.L. Scuola - Sicilia c. Italia); en ella se denunciaba la vulneración de diversas disposiciones de la CSE revisada (artículos 12, 25 y E) por parte de la legislación italiana sobre protección social (señaladamente el Decreto interministerial $n^{\circ} 83473$ de 1 de agosto de 2014) por la supuesta exclusión, en Sicilia, de los empleados del sector de la enseñanza en lo atinente al sistema del fondo o caja pagadora de los complementos de salarios (La Cassa Integrazione Guadagni in deroga), dado que dicha caja o fondo de compensación de ingresos (que es cofinanciada por el Estado y las Regiones) estaría reservada a las personas jurídicas calificadas como "empresas" y a sus trabajadores que hayan perdido su empleo (para evitar que estén en situación de desempleo completo o parcial), no compensando en cambio a los empleados de los organismos de formación constituidos como asociación con fin no lucrativo.

Por el contrario, el CEDS (tras reconducir el análisis de los argumentos impugnatorios solamente al artículo $12 \mathrm{CSE}$ ) concluyó por unanimidad que no había violación del artículo $12 \S 1$ CSE, y por 9 votos contra 5 que tampoco había violación del artículo 12§3. Para alcanzar la primera conclusión no vulneratoria, el CEDS da por buenas esas restricciones del sistema sui generis de la caja de compensación de salarios, dado que en cualquier caso "el régimen de subsidio de desempleo italiano prevé prestaciones y se extiende a todos los asalariados del sector privado" (\$57); y la segunda conclusión se basa en la ausencia de acreditación de elementos que permitan constatar que las restricciones denunciadas sea desproporcionadas a la vista de la situación financiera del país, el contexto económico de los centros de formación en Sicilia y los propios esfuerzos reformistas para preservar los dispositivos que integran el sistema de seguridad social a la vista de las disponibilidades presupuestarias y los recursos limitados. Diversamente, Petros Stangos redactó un argumentado voto particular discrepante, fundado sólidamente en el principio de proporcionalidad, sosteniendo la vulneración del artículo $12 \S 3$ por el impacto desproporcionado, injustificado e irrazonable de esas restricciones en el acceso a las prestaciones sociales controvertidas.

\section{Jurisprudencia sobre derechos laborales y sindicales o de acción colectiva}


Una primera y relevante resolución del CEDS en este bloque jurisprudencial de derechos laborales fue la decisión de fondo de 12 de septiembre de 2017 (hecha pública el 12 de febrero de 2018), mediante que la se enjuició la Reclamación n⿳0 112/2014 (Organización Europea de Asociaciones Militares, EUROMIL c. Irlanda), en donde la organización reclamante denunció que las asociaciones representativas de las fuerzas armadas en dicho país no disfrutan plenamente de los derechos sindicales, alegando la violación de los artículos 5 y 6 CSE revisada. En su decisión, el CEDS concluyó que había violación tanto del artículo 5 (a causa de la prohibición a dichas asociaciones representativas militares de afiliarse a las organizaciones profesionales nacionales) como del artículo $6 \$ 2$ (por cuanto no se garantiza a dichas asociaciones representativas de las fuerzas armadas un acceso suficiente a las negociaciones salariales), desestimando en cambio el motivo impugnatorio basado en el artículo $6 \$ 4$ (al avalar la "prohibición absoluta" del derecho de huelga a las fuerzas armadas, tras considerar que la legislación litigiosa "es proporcionada al fin legítimo perseguido y, por consiguiente, puede estimarse necesaria en una sociedad democrática", §117). Desde este punto de vista, el CEDS hace prevalecer el margen de apreciación nacional y se alinea con la postura más restrictiva de los Estados Miembros del Consejo de Europa (la gran mayoría, con la excepción de Austria y Suecia), en nombre de "la especificidad de las tareas realizadas por los miembros de las fuerzas armadas, su situación particular que les obliga respetar la disciplina militar y el hecho de que toda acción colectiva podría perturbar intervenciones hasta al punto de comprometer la seguridad nacional"' (de nuevo, §117).

Siempre en el ámbito de las fuerzas armadas, pero bajo otro ángulo, debe mencionarse la decisión de fondo de 13 de septiembre de 2017 (publicada el 29 de enero de 2018), de resolución de la Reclamación colectiva no 115/2015 (Federación europea del personal de los servicios públicos c. Grecia); en ella, la organización reclamante denunciaba la violación de los artículos $1 \S 2$ (prohibición del trabajo forzado) y $18 \S 4$ (derecho de salida de los nacionales) en perjuicio de los oficiales médicos de las fuerzas armadas en Grecia (a consecuencia de la duración del servicio obligatorio que se les impone en aplicación de la Ley griega $n^{\circ}$ 3257/2004). Ambas alegaciones fueron rechazas por el CEDS, mediante una conclusión desestimatoria: de un lado, haciendo prevalecer el margen de apreciación nacional ( $\S 45-46)$ en cuanto a esa exigencia de duración del servicio obligatorio para compensar el coste invertido por el Estado en su formación, además de dichos oficiales médicos recibir una remuneración y otras ventajas y privilegios, que comprende incluso la posibilidad de trabajar, durante su período de servicio, en el sector privado; de otro lado, haciendo notar que "durante el período de servicio (voluntario u obligatorio9, los médicos militares no pueden abandonar Grecia para ejercer una actividad lucrativa en el extranjero. Sin embargo, una vez han quedado liberados de sus obligaciones, no hay ninguna restricción para ejercer su derecho bajo el ángulo del artículo $18 \S 4$ de la Carta de 1961” (§ 52).

Una tercera queja colectiva que reviste interés fue la resuelta mediante decisión 
de fondo de 21 de marzo de 2018 (hecha pública el 27 de agosto de 2018), concretamente la Reclamación no 116/2015 (Matica hrvatskih sindikata c. Croacia), que contestaba el recorte de los derechos sindicales y de acción colectiva (artículos 5 y 6 CSE) en detrimento del personal de la función pública mediante legislación anticrisis adoptada en dicho países en 2012 (declarada admisible en fecha 30 de junio de 2015). En su decisión, el CEDS concluyó que no se habían vulnerado los artículos 5 (por cuanto las alegaciones del sindicato reclamante se basaban en una previsión de un proyecto de ley que no se plasmó en la normativa finalmente aprobada), $6 \$ 1$ (no siendo necesario establecer un mecanismo de consulta específico para todas las cuestiones de interés si los interlocutores sociales han podido participar a través de otras vías apropiadas, por ejemplo en el seno del Consejo Económico y Social), $6 \S 3$ (al no haber quedado acreditado que el breve plazo establecido a efectos de conciliación haya obstaculizado esta) y $6 \S 4$ (al no haber quedado demostrado tampoco para el CEDS que haya habido restricciones desproporcionadas al derecho de huelga), acogiendo únicamente la violación del artículo 6§2: con relación a dicha violación, el CEDS no acepta la anulación de los convenios colectivos básicos acordados en algunos sectores públicos a través la ley (promovida por el Gobierno mediante el correspondiente proyecto) de supresión de algunos derechos adquiridos fundamentales de los empleados de los servicios públicos (Ley publicada en el Diario Oficial $n^{\circ} 143 / 2012$ ), por cuanto "constituye una injerencia en el proceso de negociación colectiva" ( $\$ 87$ ) que constituye una medida muy grave únicamente susceptible de justificación a la luz de las condiciones excepcionales establecidas en el artículo 31 CSE de 1961 ( $\$ 88$ ); ahora bien, aunque la intervención legislativa litigiosa estaba prevista por la ley y justificada por el Gobierno para mantener la estabilidad presupuestaria del servicio público, el CEDS considera que "no ha quedado acreditado que la intervención en la negociación colectiva era necesaria en una sociedad democrática conforme al fin perseguido, es decir, que la restricción debía ser proporcionada al fin legítimo perseguido" (§ 89).

En terrenos análogos quedó abonada la decisión de fondo del CEDS de fecha 3 de julio de 2018, de resolución de la Reclamación no 118/2015 (Confederación General del Trabajo-Fuerza Obrera c. Francia) en donde se ponía en entredicho, esgrimiendo la violación de los artículos 5 y $6 \$ 2$ CSE revisada, la legislación francesa relativa a la protección social complementaria de los asalariados en lo que afecta a la elección del organismo asegurador (en particular, el artículo L. 912-1 del Código de la Seguridad Social, en su redacción dada por Ley n ${ }^{\circ}$ 2013-1203 de 23 de diciembre de 2013 de financiación de la Seguridad Social para 2014 y sus decretos de aplicación). La conclusión del CEDS que no hubo vulneración del artículo $6 \$ 2$ en cuanto a la disminución del número de convenios colectivos en materia de previsión social (dicha reducción no habría demostrado en sí un efecto perjudicial) o a la adopción tardía de los decretos de aplicación de la Ley de 23 de diciembre de 2013 (que para el CEDS vendría avalada por el margen de apreciación nacional y no suscitaría cuestión alguna bajo el prisma del articulo 6\$2), ni tampoco en lo referente a las reglas de competencia (al no haber quedado acreditado un conflicto de intereses o favoritismo en la recomendación de los organismos 
de previsión seleccionados -en este caso, tampoco se acepta la violación, invocada conjuntamente, del artículo 5 CSE-); por el contrario, el CEDS sí que concluyó que se había conculcado el artículo $6 \$ 2$ en lo referente a la prohibición de las cláusulas de designación, pues con ello quedaban coartados de facto y de manera desproporcionada los poderes de negociación colectiva de los interlocutores sociales en el nivel del ramo o sector de actividad, con una prohibición muy general que no tiene presentes los "malos riesgos" en sectores específicos en donde los asalariados cambian frecuentemente de empleadores, por lo que en definitiva esa prohibición general no es necesaria en una sociedad democrática al no ser proporcionada al fin legítimo perseguido a la luz del artículo G CSE revisada ( $§ 74-76)$.

A continuación, una conclusión de no violación del artículo 6\$2 CSE revisada se alcanzó en la decisión de fondo de 12 de septiembre de 2018 (publicada el 12 de diciembre de 2018), mediante la que el CEDS se enfrentó al enjuiciamiento de los motivos impugnatorios planteados en la Reclamación colectiva $n^{\mathbf{0}}$ 123/2016 (Irish Congress of Trade Unions c. Irlanda); en ella, la organización reclamante denunciaba que la decisión de la Autoridad irlandesa de la competencia prohibía a determinados trabajadores (considerados como autónomos o por cuenta propia, tales como los actores que prestan su voz -es decir,, actores de doblaje-, los periodistas "free-lance" y algunos músicos) la posibilidad de concluir convenios colectivos con objeto de fijar las bases del salario mínimo y demás condiciones laborales para poder entrar en sana competencia en el mercado laboral, lo que se saldaría en una violación del derecho a la negociación colectiva reconocido en la citada disposición de la CSE revisada. Sin embargo, el CEDS desestimó la demanda colectiva concluyendo que no se produjo la violación alegada, acogiendo así la contestación gubernamental según la cual la parte reclamante no había discernido claramente en su planteamiento procesal entre la idea de trabajador autónomo "independiente" y de trabajador autónomo "económicamente dependiente" (§ 110); diversamente el voto particular discrepante común suscrito por dos miembros del CEDS (Petros Stangos y Barbara Kresal) entendió que las autoridades irlandesas gozan de un excesivo poder de apreciación subjetiva en cuanto a la consideración de las diversas categorías de trabajadores autónomos que va contra la "promoción" de la negociación colectiva requerida por el artículo $6 \$ 2$ CSE. De todos modos, lo más interesante de esta decisión es que vuelven a suscitarse las sinergias y potenciales divergencias entre el Derecho de la UE y la CSE ( $\S 113-115)$, puesto que la organización reclamante alegaba que "es la misma existencia del Derecho de la UE en Irlanda, Estado miembro de la UE, lo que constituye una violación del artículo 6\$2 CSE haciendo ilegal la negociación colectiva de los trabajadores autónomos", frente a lo cual el CEDS responde que, pese a no aceptar una presunción general de conformidad del Derecho de la UE con la CSE, "no puede evaluar el riesgo potencial que constituiría la aplicación del Derecho de la UE, sino solamente su ejecución efectiva por el Derecho interno" (§ 115).

Volviendo a los derechos de sindicación y acción colectiva de institutos armados con disciplina militar (pero policía militar), debe mencionarse la decisión de fondo del 
CEDS de 22 de enero de 2019 (hecha pública el 7 de junio de 2019), mediante la que se resolvió la Reclamación colectiva no 140/2016 (Confederazione Generale Italiana del Lavoro, CGIL, c. Italia); en concreto, el sindicato reclamante denunciaba la imposibilidad, para los miembros de la Guardia de Finanzas (Guardia di Finanza), de constituir sindicatos y desarrollar la actividad sindical, así como de ejercer el derecho de negociación colectiva, alegándose la violación de los artículos 5 y 6 CSE revisada respectivamente. En su decisión, tras tomar en consideración el estatuto de la Guardia di Finanza (§§ 41-42) como "fuerza de policía militar dotada de competencias generales en materia económica y financiera" que "forma parte integrante de las fuerzas armadas del Estados y de las autoridades encargadas del mantenimiento del orden", sometida al Código de disciplina militar del Ejército italiano así como al Código penal militar y bajo la autoridad jerárquica de diversos Ministerios (en función de las competencias y operaciones que desempeñe, Ministerio de Economía y Hacienda, Ministerio del Interior y Ministerio de Defensa), declaró en primer término la violación del artículo 5 CSE, como consecuencia de la prohibición completa de los miembros de la Guardia di Finanza de constituir sindicatos u organizaciones profesionales ( $(83)$ afiliarse a sindicatos ( $(93)$, restringiéndose con ello el derecho de sindicación "de una manera no necesaria en una sociedad democrática para la protección, en particular, de la seguridad nacional en el sentido del artículo G de la Carta (...) independientemente de la naturaleza civil o militar de las tareas que les son encomendadas" ( $(98)$; y, a tal efecto, tuvo en consideración tanto otros textos internacionales del Consejo de Europa y de Naciones Unidas (incluida la OIT) como la jurisprudencia previa en la materia del TEDH (entre otras, sentencias de 2 de octubre de 2014 en el caso ADEFDROMIL c. Francia, de 4 de octubre de $2014 \mathrm{n}$ el caso Matelly c. Francia, o de 21 de abril de 2015 en el caso Junta Rectora del Ertzainen Nazional Elkartasuna c. España) y del propio CEDS (entre otras, decisiones de fondo de 2 de diciembre de 2013 en la Reclamación n ${ }^{\circ}$ 83/2012, Confederación Europea de Policía, EuroCOP c. Irlanda, o de 27 de enero de 2016 en la Reclamación no 101/2013, Consejo Europeo de Sindicatos de Policía, CESP c. Francia), o de la Corte Constitucional Italiana (Sentencia $n^{\circ} 120 / 2018$ de 11 de abril de 2018, a tenor de la cual el personal militar está habilitado a constituir sindicatos -§ 77-).

De igual manera, el CEDS concluyó la violación del artículo $6 \$ 2$ (por no contar los órganos de representación de la Guardia di Finanza con los medios para negociar efectivamente las condiciones de empleo, incluida la remuneración, de sus miembros) y del artículo $6 \$ 4$ (al considerar "que la prohibición absoluta del derecho de huelga impuesta a los miembros de la Guardia di Finanza no es proporcional al objetivo legítimo perseguido y, por tanto, no es necesaria en una sociedad democrática" - $\$ 152-$ ). Sin embargo, no se acogió por el CEDS la alegación de vulneración del artículo $6 \$ 1$ (al no quedar acreditado que no se favorezca la consulta paritaria entre los miembros de la Guardia di Finanza y su empleador, el Ministerio de Economía y Hacienda, o que no sean eficaces en la práctica los mecanismos de consulta existentes).

En un ámbito similar al anterior y frente al mismo país, debe citarse la decisión de fondo de 3 de julio de 2019 (publicada el 26 de noviembre de 2019), mediante la 
que el CEDS resolvió la Reclamación colectiva no 143/2017 (UGL-CFS -Unione Generale Lavoratori-Federazione Nazionale Corpo forestale dello Stato- y SAPAF Sindacato autonomo polizia ambientale forestale- c. Italia), mediante la que las organizaciones sindicales denunciantes (alegando la violación de los artículos 1§2, 5, 6, E y G de la CSE revisada) argumentaban que, a través del Decreto legislativo no 177/2016 que incorpora el cuerpo forestal del Estado a los Carabinieri, con la correspondiente adquisición del estatuto militar, Italia priva a dicho cuerpo forestal de sus derechos sindicales y de acción colectiva. De entrada, el CEDS concluyó que el artículo $1 \S 2$ no era aplicable (al no quedar acreditado que haya habido discriminación en el empleo o trabajo forzado u obligatorio ni se suscitara esa cuestión por el cambio de estatuto del cuerpo forestal como consecuencia de la reorganización de las actividades del sector público - §§ 76-77-, teniendo presente que la mayoría decidió incorporarse al cuerpo de carabineros, quedando no obstante la opción de seguir en otro puesto manteniendo el estatuto civil). Por el contrario, y justamente haciéndose eco por analogía de la precedente decisión de fondo de 22 de enero de 2019 relativa a la Reclamación colectiva no 140/2016 (CGIL, c. Italia) sobre el estatuto de la Guardia di Finanza, el CEDS sí concluyó que hubo violación del artículo 5 ( $\S 101-105)$ y del artículo $6 \S 2$ (§§ 119-122) por análogos motivos a los desarrollados en esa previsión resolución de fondo.

En otro ámbito laboral, el CEDS había adoptado antes la decisión de fondo de 14 de octubre de 2018 (hecha pública el 15 de marzo de 2019), de resolución de la Reclamación colectiva $\mathrm{n}^{\circ}$ 154/2017 (CGT, Confédération générale du travail c. Francia), en la que el sindicato reclamante denunciaba la vulneración del artículo $4 \S 2$ CSE revisada, esgrimiendo que la Ley 2016-1088 de 8 de agosto de 2016 (relativa al trabajo, la modernización del diálogo social y la seguridad de las carreras profesionales) que autoriza la organización del tiempo de trabajo sobre un período superior a la semana susceptible de mantenerse hasta tres años vulneraría la citada disposición, en la medida en que privaría al trabajador de su derecho a una remuneración equitativa y, en particular, a un aumento por las horas de trabajo extraordinarias. En su fallo, el CEDS concluyó primeramente que hubo violación del citado precepto de la Carta Social en lo concerniente al carácter razonable del período de referencia, por cuanto si bien cabía aceptar un período que no exceda de doce meses en circunstancias excepcionales (justificadas por motivos objetivos o técnicos, o razones relativas a la organización del trabajo), en cambio un período de referencia superior a doce meses y susceptible incluso de alcanzar tres años resulta inasumible, dado que "ese mayor esfuerzo de los asalariados no quedaría compensado por un aumento del salario y no cabría considerar que el tiempo de descanso concedido pueda constituir una compensación adecuada, a la vista de la duración potencial de las horas extraordinarias. Ello podría tener asimismo efectos negativos en la salud y la seguridad, así como en el equilibrio entre la vida profesional y la vida privada de los asalariados", lo cual resulta en definitivo irrazonable y contrario al artículo $4 \S 2$ CSE revisada ( $\S 60-61$ ). De otro lado, en sentido contrario, el CEDS concluyó que no se produjo violación del artículo $4 \S 2$ en cuanto al derecho de los trabajadores de ser informados de todo cambio de horarios de trabajo, tanto más cuanto que el propio 
sindicato reclamante no ha denunciado que esas exigencias informativas establecidas por el Código de Trabajo no habrían sido respetadas en la práctica, considerando así el CEDS que las garantías previstas por el Código para prevenir a los asalariados de sus horarios de trabajo "son apropiadas y, consecuentemente conformes a la Carta" (§§ 64-66).

Un último pronunciamiento, de gran envergadura tanto en clave de análisis de las reformas laborales flexibilizadoras como de sinergias con otros estándares internacionales y constitucionales, ha sido la decisión de fondo del CEDS de 11 de septiembre de 2019 (hecha pública el 11 de febrero de 2020), sobre resolución de la Reclamación colectiva $\mathrm{n}^{\circ}$ 158/2017 (CGIL, Confederazione Generale Italiana del Lavoro c. Italia); en ella, el sindicato reclamante denunciaba la vulneración del derecho a la protección en caso de despido del artículo 24 CSE revisada, por cuanto el Decretoley $\mathrm{n}^{\circ}$ 23/2015 relativo a la protección aplicable a los asalariados del sector privado en caso de despido ilegal prevé un mecanismo de cálculo de la indemnización que establecería un tope desvinculado del perjuicio real sufrido por el trabajador o trabajadora; norma corroborada por el posterior Decreto-ley n ${ }^{\circ} 87$ de 12 de julio de 2018 (pese a haber aumentado esta última norma los montantes mínimo y máximo de la indemnización prevista por la disposición precedente). El caso es que el CEDS acogió la demanda colectiva, estimando efectivamente que hubo violación de la citada disposición, tras concluir que "ni las vías jurídicas alternativas que ofrecen al trabajador víctima de despido ilegal una posibilidad de reparación más allá del límite establecido por la ley vigente, ni el mecanismo de conciliación, tal como se prevén por las disposiciones litigiosas, permiten en todos los casos de despido sin motivo válido obtener una reparación adecuada, proporcional al perjuicio sufrido y susceptible de disuadir para recurrir a los despidos ilegales" ( $\S \S 104-105)$. En realidad, se trata de una conclusión que, de algún modo, contaba con el aval de la jurisprudencia del propio CEDS en el sistema de informes y en el mecanismo de reclamaciones colectivas, además de afortunadamente coincidir con la propia jurisprudencia constitucional italiana, como se pone de manifiesto en la misma decisión de fondo ( $\$ 96)$ : “El Comité recuerda que cualquier tope o limite que pueda tener el efecto de que las indemnizaciones otorgadas no estén en relación con el perjuicio sufrido y no sean suficientemente disuasorias es, en principio, contrario a la Carta, como lo ha declarado también, en cierta medida, la Corte Constitución italiana en su sentencia $n^{0}$ 194/2018. En caso de tope de las indemnizaciones otorgadas como compensación por el perjuicio material, la víctima debe poder pedir reparación por el perjuicio moral sufrido a través de otras vías jurídicas, y las jurisdicciones competentes para otorgar una indemnización por el perjuicio material y moral sufrido deben pronunciarse en un plazo razonable (Finnish Society of Social Rights c. Finlandia, Reclamación n $n^{\text {10 }}$ 106/2014, decisión de admisibilidad y de fondo de 8 de septiembre de 2016, § 46, Conclusiones 2012, Eslovenia y Finlandia)".

Esta decisión de fondo de 11 de septiembre de 2019 sobre la Reclamación n $^{\text {o }}$ 158/2017 merece unos ulteriores comentarios. En efecto, es cierto que la Sentencia no 194 de 25 de septiembre de 2018 de la Corte Constitucional italiana declaró la ilegitimidad 
constitucional de la limitación de la indemnización por despido establecida en el artículo 3, apartado 1, del Decreto-ley n 87 de 12 de julio de 2018 sobre disposiciones urgentes para la dignidad de los trabajadores y de las empresas (Disposizioni urgenti per la dignità dei lavoratori e delle imprese), norma conocida en Italia con el anglicismo "Jobs Act". Es verdad igualmente que la Corte Constitucional tomó en consideración en su fundamento jurídico 14 "la idoneidad de la Carta Social Europea para integrar el parámetro del artículo 117, apartado primero, de la Constitución, y también ha reconocido la autoridad de las decisiones del Comité [Europeo de Derechos Sociales], aunque no vinculantes para los jueces nacionales (Sentencia $n^{\circ} 120$ de 2018)". Por consiguiente, la Corte Constitucional establece un delicado equilibrio, por un lado al declarar ese carácter no vinculante de las decisiones del CEDS y, por otro lado, al destacar en ese mismo fundamento jurídico 14 la relevancia interpretativa de la Carta Social Europea revisada, porque "evidentemente, el artículo 24 [de la Carta], que se inspira en la ya mencionada Convención no 158 de 1982 de la OIT, especifica en el plano internacional, en armonía con el artículo 35, apartado tercero, de la Constitución, con respeto al despido injustificado, la obligación de garantizar la adecuación de la indemnización".

Verdaderamente es desafortunada e innecesaria esa manifestación de la Corte Constitucional italiana (que lógicamente rechazo) sobre la no vinculatoriedad de las resoluciones del CEDS, pues establece un artificial discernimiento entre fase de interpretación (de la norma constitucional a la luz de la norma internacional -de la Carta Social Europea-) y fase de aplicación (de la resolución de la instancia internacional -el CEDS- habilitada por la propia norma internacional para llevar a cabo la interpretación auténtica de ella). Y es desafortunada e innecesaria porque ello puede tener el efecto de disuadir a las jurisdicciones nacionales a la hora de secundar la interpretación internacional, eventualmente ejerciendo el control de convencionalidad. A este respecto, ya sabemos que en otros países europeos como Francia, el control de convencionalidad cuenta con larga tradición y experiencia: en el ámbito particular que nos ocupa, y pese a la postura reticente de su corte suprema del orden social a la hora de asumir el parámetro de la CSE (Pleno de la Corte de Casación, dictámenes no 15012 y 15013 de 17 de julio de 2019, procedentes respectivamente de los consejos de "prud'hommes" de Louviers y de Toulouse ${ }^{20}$ ), los órganos jurisdiccionales sociales han asumido el canon internacional frente a la reforma introducida en 2017 en el Código de Trabajo (artículo L. 1235-3-1 del Code $d u$ travail) precisamente en esa materia de establecimiento de límite de las indemnizaciones por despido abusivo (plafonnement des indemnités pour licenciement abusif). En particular, desde finales de 2018 ha habido numerosos pronunciamientos de los Conseils de Prud'hommes mediante los que han decidido no aplicar la norma nacional controvertida por ser contraria al artículo 10 del Convenio $\mathrm{n}^{\mathrm{o}} 158$ de la OIT sobre terminación de la relación de trabajo y al artículo $24 \mathrm{CSE}$ revisada ${ }^{21}$; lo cual cuenta ahora,

\footnotetext{
${ }^{20}$ En la parte dispositiva de ambos dictámenes se declara: "Las disposiciones del art. 24 de la Carta social europea revisada no tienen efecto directo en Derecho interno en un litigio entre particulares" ("Les dispositions de l'article 24 de la Charte sociale européenne révisée ne sont pas d'effet direct en droit interne dans un litige entre particuliers").

${ }^{21}$ Tales pronunciamientos han sido ilustrativamente percibidos en clave de "revuelta y «coherencia» de los Conseils de prud'hommes frente a la modificación de las indemnizaciones por despido injustificado: el
} 
no únicamente con el soporte de la jurisprudencia del CEDS en el sistema de informes, sino con el reciente espaldarazo de su decisión de fondo de 11 de septiembre de 2019 (CGIL) c. Italia), sin perjuicio de las reclamaciones colectivas formuladas (alegando igualmente la violación del artículo 24 CSE revisada), en estado de litispendencia, ante el mismo CEDS frente a Francia con relación a esa controvertida reforma ${ }^{22}$.

\section{PERSPECTIVAS JURISPRUDENCIALES}

A lo largo de la presente crónica cabe comprobar que la jurisprudencia del CEDS correspondiente a 2018 a 2019 ha acometido aspectos importantes referentes al ámbito material y personal de los derechos garantizados por la CSE, tanto en el sistema de informes como en el procedimiento de reclamaciones colectivas. Se trata de aspectos que han devenido verdaderos desafíos en el contexto de la pandemia provocada por el COVID-19, en la línea avanzada por el CEDS en su reciente Observación interpretativa (adoptada el 21 de abril de 2020) sobre el derecho a la protección de la salud en tiempos de pandemia. En efecto, el CEDS deberá afinar sus análisis y hacerse eco de esas nuevas realidades y necesidades para la garantía real de los derechos humanos consagrados en la CSE, para así seguir consolidándose como la instancia europea por excelencia de protección de los derechos sociales: si la crisis económica y financiera iniciada en 2008 fue germen de una relevante jurisprudencia "anticrisis", la actual crisis sanitaria y humanitaria abocará al CEDS a elaborar una novedosa jurisprudencia "anti-COVID-19" compensatoria de los efectos socio-económicos de la pandemia y ésta no genere una crisis general de derechos humanos y de valores. Por descontado, la presente crónica vuelve a poner de manifiesto la necesidad de profundizar en las sinergias entre el Consejo de Europa y la Unión Europea y, por ende, de impulsar el conocido "Proceso de Turín" y de dotar de impacto al programático (soft-law) "Pilar Europeo de Derechos Sociales".

En lo que atañe al sistema de informes, durante el año 2020, el desarrollo jurisprudencial que acometerá el CEDS versará sobre el grupo temático I, centrado especialmente en "Empleo, formación e igualdad de oportunidades", es decir, los artículos 1 (derecho al trabajo), 9 (derecho a la orientación profesional), 10 (derecho a la formación profesional), 15 (derecho de las personas con discapacidad a la autonomía, a la integración social y a la participación en la vida de la comunidad), 18 (derecho a ejercer

Convenio núm. 158 de la OIT y la CSE revisada como trinchera de resistencia": SALCEDO BELTRÁN, C.: "Sinergias entre la OIT y los instrumentos internacionales de protección de los derechos sociales: estado actual y perspectivas", Revista de Trabajo y Seguridad Social-CEF, n $\mathrm{n}^{\circ}$ 434, 2019, p. 184.

${ }^{22}$ Entre ellas, la Reclamación no 160/2018, Confederación General del Trabajo-Fuerza Obrera, CGT-FO c. Francia (registrada el 12 de marzo de 2018 y admitida el 11 de septiembre de 2018), Reclamación $n^{\circ}$ 171/2018, CGT c. Francia, registrada el 7 de septiembre de 2018 y admitida el 3 de julio de 2019), la Reclamación n ${ }^{\circ}$ 175/2019, Sindicato CFDT de la Metalurgia de la Meuse c. Francia (registrada el 31 de enero de 2019 y admitida el 28 de enero de 2020), la Reclamación nº 176/2019, Unión Sindical Solidarios SDIS c. Francia (registrada el 5 de febrero de 2019 y admitida el 6 de diciembre de 2019), la Reclamación $\mathrm{n}^{\circ}$ 181/2019, Sindicato CFDT general de los transportes y del medio ambiente de l'Aube c. Francia (registrada el 20 de mayo de 2019 y admitida el 13 de mayo de 2020) y la Reclamación no 182/2019, Sindicato CFDT de la Metalurgia de la Meuse c. Francia (registrada el 20 de mayo de 2019 y admitida el 13 de mayo de 2020). 
una actividad lucrativa en el territorio de otras Partes Contratantes), 20 (derecho a la igualdad de oportunidades y de trato en materia de empleo y de profesión, sin discriminación por razón de sexo), 24 (derecho a la protección en caso de despido) y 25 (derecho de los trabajadores a la tutela de sus créditos en caso de insolvencia de su empleador). Al respecto, conviene efectuar dos observaciones: la primera, que se trata de un bloque temático fundamental, por cuanto su análisis servirá para ponderar los efectos de la crisis del COVID-19; la segunda, que lamentablemente las dos últimas e importantes disposiciones mencionadas (artículos 24 y 25) no podrán ser objeto de control con relación a España al no haber ratificado ésta el texto revisado de 1996 (el artículo 20 es equivalente al artículo 1 del Protocolo adicional de 1988, que España sí ratificó).

En lo que concierne al mecanismo de reclamaciones colectivas, las perspectivas jurisprudenciales para 2020 pasan por tener en cuenta, de un lado, que hay casi medio centenar de reclamaciones formuladas en estado de litispendencia que deberán propiciar un apuntalamiento y consolidación de la jurisprudencia del CEDS y, a buen seguro, despejar nuevas interpretaciones que favorezcan el disfrute efectivo de los derechos reconocidos en la CSE; y, de otro lado, que algunas de las decisiones de fondo adoptadas o publicadas en 2020 (que serán objeto de análisis en la crónica de 2020) abordan retos cruciales como la lucha contra la brecha salarial de género ${ }^{23}$, mientras otras enjuiciarán la afectación de la crisis del COVID-19 a derechos socio-laborales (pensemos en el enorme número de despidos y personas desempleadas a causa de la pandemia) de una relevancia especial para el respeto de la dignidad y de una vida digna de ser vivida.

Reseñado lo precedente, con relación al procedimiento de reclamaciones colectivas, es pertinente insistir una vez más en que no parece razonable que España quede al margen de los países que sí han aceptado el Protocolo de 1995, entre los que se encuentran nuestros vecinos Francia, Italia y Portugal; la situación resulta tanto más paradójica cuanto que, como se comentó, España sí se ha vinculado (en septiembre de 2010) por el sistema de quejas individuales ante el Comité de Derechos Económicos Sociales y Culturales de Naciones Unidas introducido mediante el Protocolo facultativo de 2008, que alcanzó vigencia el 5 de mayo de 2013 tras reunirse las diez ratificaciones requeridas. Parece incomprensible que España sólo se siga viendo afectada

\footnotetext{
${ }^{23}$ Se trata de las decisiones de fondo adoptadas por el CEDS los días 5 y 6 de diciembre de 2019 (hechas públicas el 29 de junio de 2020) que se formularon contra quince países (es decir, contra todos los Estados Partes que han aceptado el mecanismo de reclamaciones colectivas) en las que se denuncia la brecha salarial entre mujeres y hombres en perjuicio de las primeras. En concreto, me refiero a las decisiones de fondo que resuelven las reclamaciones $n^{\circ} 124 / 2016$ a 138/2016, formuladas todas ellas el 24 de agosto de 2016 por la organización University Women of Europe (UWE, Grupo europeo de mujeres diplomadas universitarias), respectivamente contra Bélgica, Bulgaria, Croacia, Chipre, República Checa, Finlandia, Francia, Grecia, Irlanda, Italia, Países Bajos, Noruega, Portugal, Eslovenia y Suecia (todas ellas admitidas en fecha 4 de julio de 2017). En ellas se denunciaba la vulneración de los artículos 1 (derecho al trabajo), 4.3 (derecho a una remuneración equitativa en su vertiente de no discriminación entre mujeres y hombres) y 20 (derecho a igualdad de oportunidades y trato en materia de empleo sin discriminación sexual) en conjunción con el artículo E (no discriminación) de la CSE revisada (o disposiciones equivalentes de la CSE de 1961). Cabe avanzar, sin perjuicio del análisis particular en la crónica de 2020, que todas ellas son condenatorias, con la excepción de la relativa a Suecia, país que ha quedado absuelto.
} 
indirectamente (a través de la retroalimentación favorecida por el sistema de informes) por las perspectivas jurisprudenciales que ofrece el CEDS en el examen de las reclamaciones colectivas.

Con tal espíritu, debe recalcarse, como en crónicas anteriores, que el conocimiento de la jurisprudencia del CEDS no constituye un mero reto pedagógico o de difusión en el ámbito académico o en la praxis jurídica, sino un imperativo constitucional de optimización de los artículos 10.2 y 96 de la Carta Magna española y, por ende, de nuestro sistema constitucional de derechos fundamentales, lo que obviamente proyecta un creciente impacto y mayores posibilidades de garantía de los llamados principios rectores de la política social y económica. A los mandatos constitucionales mencionados (artículos 10.2 y 96) estamos sometidos el conjunto de la ciudadanía y los poderes públicos, incluidos el Tribunal Constitucional y el Tribunal Supremo, que por tanto no habrían de mostrar reparos para hacerse eco de esa jurisprudencia del CEDS, lo mismo que sucede con la jurisprudencia del TEDH o la del TJUE. A fin de cuentas, las perspectivas jurisprudenciales ofrecidas por el CEDS deben ser tenidas en mente por los operadores jurídicos nacionales.

Cabalmente, la mayor visibilidad y eficacia de la CSE y de la jurisprudencia del CEDS no radica tanto en la ejecución de esas decisiones por los Estados condenados ni en el contenido de las resoluciones que adopte el Comité de Ministros del Consejo de Europa en el marco de esa ejecución, sino sobre todo en la asunción y aplicación directa de esa jurisprudencia por las jurisdicciones nacionales y, por supuesto, en su invocación por los profesionales de la Abogacía en los asuntos que defiendan. La Ley 25/2014, de 27 de noviembre, de Tratados y otros Acuerdos Internacionales debería facilitar, con naturalidad, esa visibilidad y esa eficacia de la CSE y de la jurisprudencia del CEDS, con el eventual ejercicio del control de convencionalidad por parte de los órganos jurisdiccionales nacionales. Llegados a este punto, parece inexorable la proyección positiva del control de convencionalidad sobre la efectividad de los derechos sociales y laborales que se deriva de la ya mencionada e importante STC 140/2018. Ese reconocimiento mediante la STC 140/2018 de la posición supralegal de los tratados y el consiguiente control difuso de convencionalidad ejercido por los órganos jurisdiccionales ordinarios sobre la base del art. $96 \mathrm{CE}$ debe completarse en el terreno de los derechos sociales y laborales, cuando menos, por otros dos factores: el primero, que el propio Tribunal Supremo español se sienta interpelado por ese control de convencionalidad, salvando aparentes obstáculos procedimentales fundados en un enfoque excesivamente rigorista y formalista de la vía casacional (artículo 219 de la Ley 36/2011, de 10 de octubre, Reguladora de la Jurisdicción Social); el segundo, que el Tribunal Constitucional español se sienta asimismo interpelado por un ejercicio del control de constitucionalidad coherente con el mandato interpretativo del art. 10.2, para que los controles de constitucionalidad y de convencionalidad convivan en condiciones de convergencia, no de concurrencia. 
Efectivamente, la evolución de la protección internacional de los derechos humanos en general (y de los derechos sociales y laborales en particular) ha acarreado la superación de la clásica distinción entre monismo y dualismo en nombre del principio favor libertatis (también conocido como pro homine o pro personae), en la medida en que la fuente nacional y la internacional se retroalimentan en una deseable acción de sinergia optimizadora. Semejante superación se explica, en buena medida, por la relativización del discernimiento entre las fases de interpretación y aplicación de las normas (nacionales e internacionales) sobre derechos sociales y laborales.

En definitiva, el objetivo primordial de la presente crónica sobre la jurisprudencia del CEDS (referente en este caso a los años 2018 y 2019) reside en difundirla para generar la conciencia en los actores nacionales sobre su rol crucial en la senda del "proceso de Turín". La voluntad positiva de todos ellos es esencial para dinamizar dicho proceso. Con ello, estarán bien empleados los esfuerzos comunes y armoniosos en vista a la consolidación de la CSE como verdadero Pacto europeo para la estabilidad social de los tres pilares del Consejo de Europa: democracia social, Estado social y derechos sociales. Con ese mismo espíritu, las sinergias entre el Consejo de Europa y la Unión Europea en el ámbito de los derechos sociales deberían seguir teniendo como referente básico y guía inexorable la Carta Social Europea en su condición de verdadera "Constitución Social de Europa" y "Pacto Europeo de Democracia Social", en una deseable convergencia propugnada por el "Proceso de Turín" y a la que debería sumarse progresiva e irreversiblemente, sin ambages, el "Pilar Europeo de Derechos Sociales".

\section{Bibliografía.}

-GONZÁLEZ DE LA RIVERA I SERRA, X.: "Conversaciones entre la norma internacional y la norma interna: la aplicación por los órganos judiciales”, en FARGAS FERNÁNDEZ, J. (Coord.): Los derechos laborales desde la perspectiva de la teoría general del contrato y de la normativa internacional, Barcelona, Huygens Editorial.

-SALCEDO BELTRÁN, C., y JIMENA QUESADA, L.: "La Carta Social Europea revisada (Constitución Social de Europa) y el Acuerdo del Consejo de Ministros: el compromiso con los derechos y ¿con sus garantías?”, 2019, en https://atdcuartomundo.es/2019/02/04/espana-mas-cerca-de-la-carta-social-europarevisada-y-tambien-de-sus-garantias/ (4 de febrero de 2019; último acceso 16 de junio de 2020).

-SALCEDO BELTRÁN, C.: "Control de convencionalidad de los tratados internacionales: bendición constitucional (STC 140/2018, de 20 de diciembre) y aceptación urbi et orbi de su enjuiciamiento por la jurisdicción ordinaria", marzo 2019 (https://baylos.blogspot.com/2019/03/legalidad-de-los-tratados.html). 
-SALCEDO BELTRÁN, C.: “Crónica Europea. Conclusiones XXI-3 (2018) del Comité Europeo de Derechos Sociales: Evidencias de la «indiferencia» $\mathrm{y}$ «resistencia» a la Carta Social Europea”, Derecho de las Relaciones Laborales, nº 5, 2019.

-SALCEDO BELTRÁN, C.: “Crónica Europea. La crítica situación de los derechos sociales de la infancia, de las familias y de los migrantes: Conclusiones 2019 del Comité Europeo de Derechos Sociales", Derecho de las Relaciones Laborales, nº 6, 2020.

-SALCEDO BELTRÁN, C.: "Sinergias entre la OIT y los instrumentos internacionales de protección de los derechos sociales: estado actual y perspectivas", Revista de Trabajo y Seguridad Social-CEF, $\mathrm{n}^{\circ}$ 434, 2019. 